\title{
The Pelagic Young and Early Bottom Stages of Teleosteans.
}

By

\author{
Robert S. Clark, M.A., B.Sc. \\ Naturalist at the Plymouth Laboratory
}

With 9 Figures in the Text.

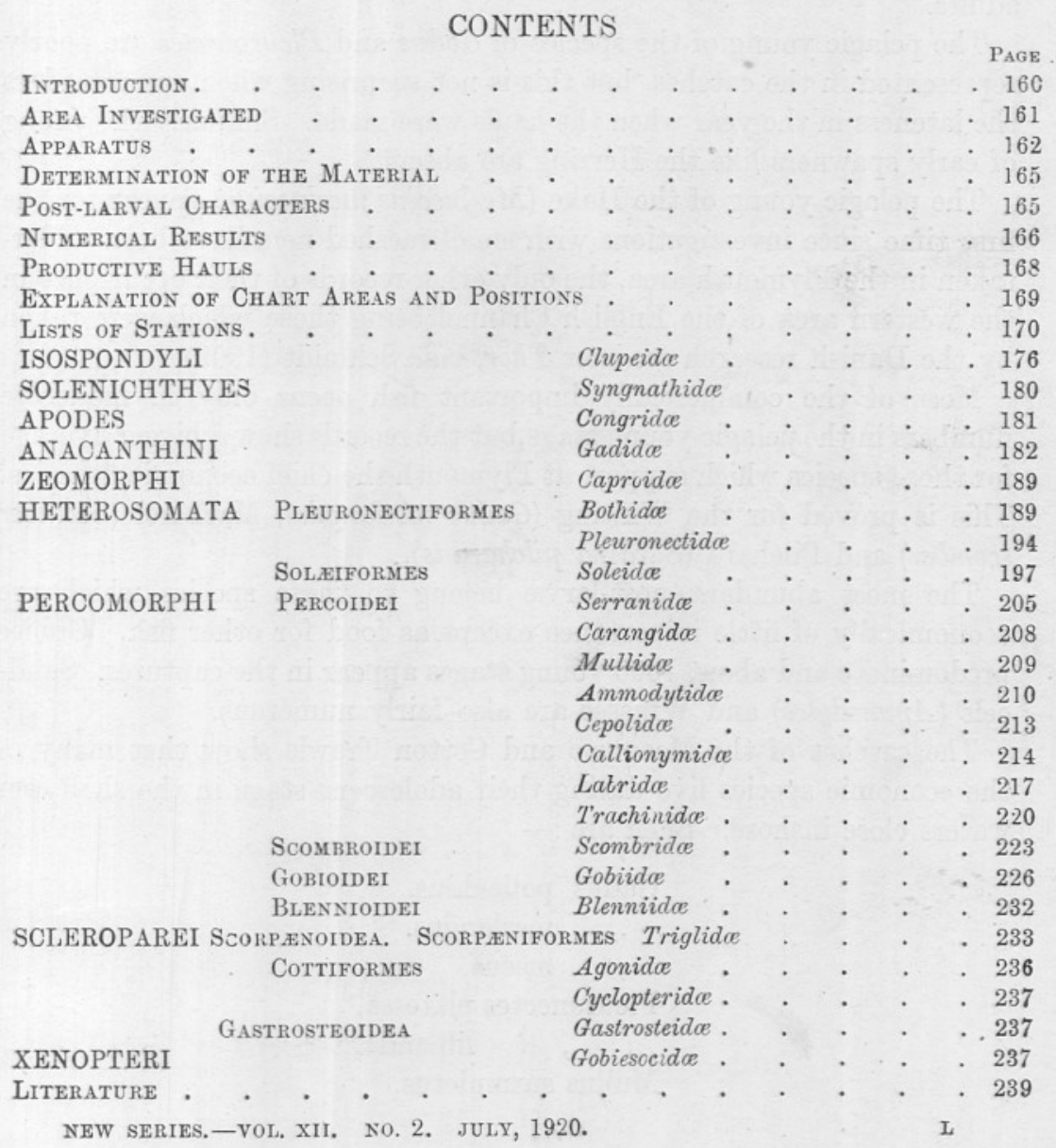




\section{INTRODUCTION.}

THe present report deals with the young fish which were collected in the neighbourhood of Plymouth during the summer and autumn of 1919, from the beginning of July to the end of September, by small meshed nets operated from the Association's steamer Oithona. It is a supplement to Dr. Allen's report on the "Post-larval Teleosteans collected near Plymouth during the Summer of 1914," published in Vol. XI, No. 2 (May, 1917), of this Journal, and to the writer's "General Report on the Larval and Post-larval Teleosteans in Plymouth Waters" in Vol. X, No. 2 (June, 1914).

The total number of fish examined amounts to 16,400 , which are referable to 24 families, 39 genera and 71 species. All the forms are stages in the life histories of fishes, which are well known as adults.

The pelagic young of the species of Gadus and Pleuronectes are poorly represented in the catches, but this is not surprising when one considers the lateness in the year when the hauls were made. Similarly the young of early spawners like the Herring are absent.

The pelagic young of the Hake (Merluccius merluccius) appear for the first time since investigations with small meshed nets have been undertaken in the Plymouth area, the only other records of their occurrence in the western area of the English Channel being those which were taken by the Danish research steamer Thor, vide Schmidt (1909).

Most of the commercially important fish occur only in moderate numbers in the pelagic young stage, but the records show a bigger average for those species which support at Plymouth the chief economic fisheries. This is proved for the Whiting (Gadus merlangus), Mackerel (Scomber scomber) and Pilchard (Sardina pilchardus).

The most abundant post-larvæ belong to those species which are economically of little importance except as food for other fish. Gobies predominate and about 7000 young stages appear in the captures. Sandeels (Ammodytes) and Wrasses are also fairly numerous.

The catches of the Mosquito and Cotton Trawls show that many of the economic species live during their adolescent stage in the shallower waters close inshore. Such are :-

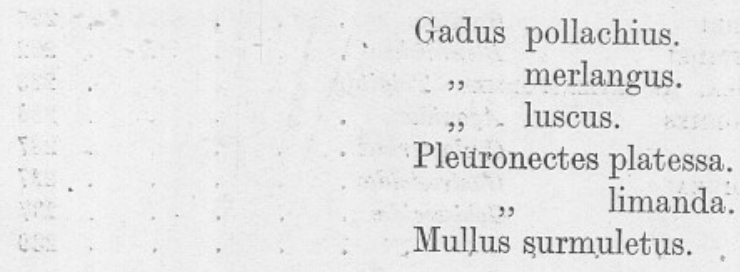




\section{Trigla gurnardus.}

, hirundo.

The spawning periods are here recorded for Plymouth area. These have been determined from the examination of ripe female fish, from the records of eggs and newly hatched larvæ whose identification has been certain, and from the occurrence of the early pelagic young.

The figures accompanying the text were kindly drawn for the writer by Mr. E. Ford, Assistant Naturalist, who also helped in the collection of the material.

\section{AREA INVESTIGATED.}

The hauls of the young fish and cotton trawls were made chiefly in the area lying between the line, Bolt Tail-Eddystone-Looe and the shore, while investigations were extended beyond the 40 -fathom line to a distance of about 25 miles S.W. of the Eddystone Rocks. The hauls are summarised for the various depths in Table 1.

\section{TABLE I.}

Apparatus. $A=$ Young Fish Trawl of stramin.

$\mathrm{B}=\quad, \quad, \quad, \quad, \quad$ mosquito netting.

$\mathrm{C}=$ Cotton Trawl $\frac{1}{2}$ mesh ( (1" $^{\prime \prime}$ square).

$\mathrm{A}$ and $\mathrm{B}$

\section{$\mathrm{C}$}

\begin{tabular}{c|ccc|ccc}
\cline { 2 - 7 } Depth in fms. & $\begin{array}{c}\text { No. of } \\
\text { Hauls. }\end{array}$ & $\begin{array}{c}\text { Duration } \\
\text { of Haul } \\
\text { in min. }\end{array}$ & $\begin{array}{c}\text { No. of hrs. } \\
\text { fishing. }\end{array}$ & $\begin{array}{c}\text { No. of } \\
\text { Hauls. }\end{array}$ & $\begin{array}{c}\text { Duration } \\
\text { of Haul } \\
\text { in min. }\end{array}$ & $\begin{array}{c}\text { No. of hrs. } \\
\text { fishing. }\end{array}$ \\
$<10$ & 17 & $22 \cdot 64$ & $6 \cdot 4$ & 15 & 30 & $7 \cdot 5$ \\
$10-20$ & 10 & $21 \cdot 5$ & $3 \cdot 5$ & 2 & 20 & $0 \cdot 6$ \\
$20-30$ & 46 & $21 \cdot 08$ & $16 \cdot 16$ & 4 & $27 \cdot 5$ & $1 \cdot 8$ \\
$30-40$ & 4 & $22 \cdot 5$ & $1 \cdot 4$ & 4 & $36 \cdot 25$ & $2 \cdot 4$ \\
$40-45$ & 7 & 30 & $3 \cdot 5$ & 6 & 30 & $3 \cdot 0$
\end{tabular}

The depths here represent the total depth of water at each station.

Systematic search was made both in the shallower waters of the bays and in the deeper water of midchannel for the adolescent stages of the young of the Mackerel, Pilchard and Anchovy, but the results were negative.

The number of hauls per month is as follows for nets A, B and C :-

TABLE II.

$\begin{array}{llrrrrr} & & & \text { A } & \text { B } & \text { C } \\ \text { July } & * & \cdot & 30 & - & - \\ \text { Aug. } & \cdot & . & 25 & 4 & 5 \\ \text { Sept. } & \cdot & . & - & 25 & 26\end{array}$




\section{Apparatus.}

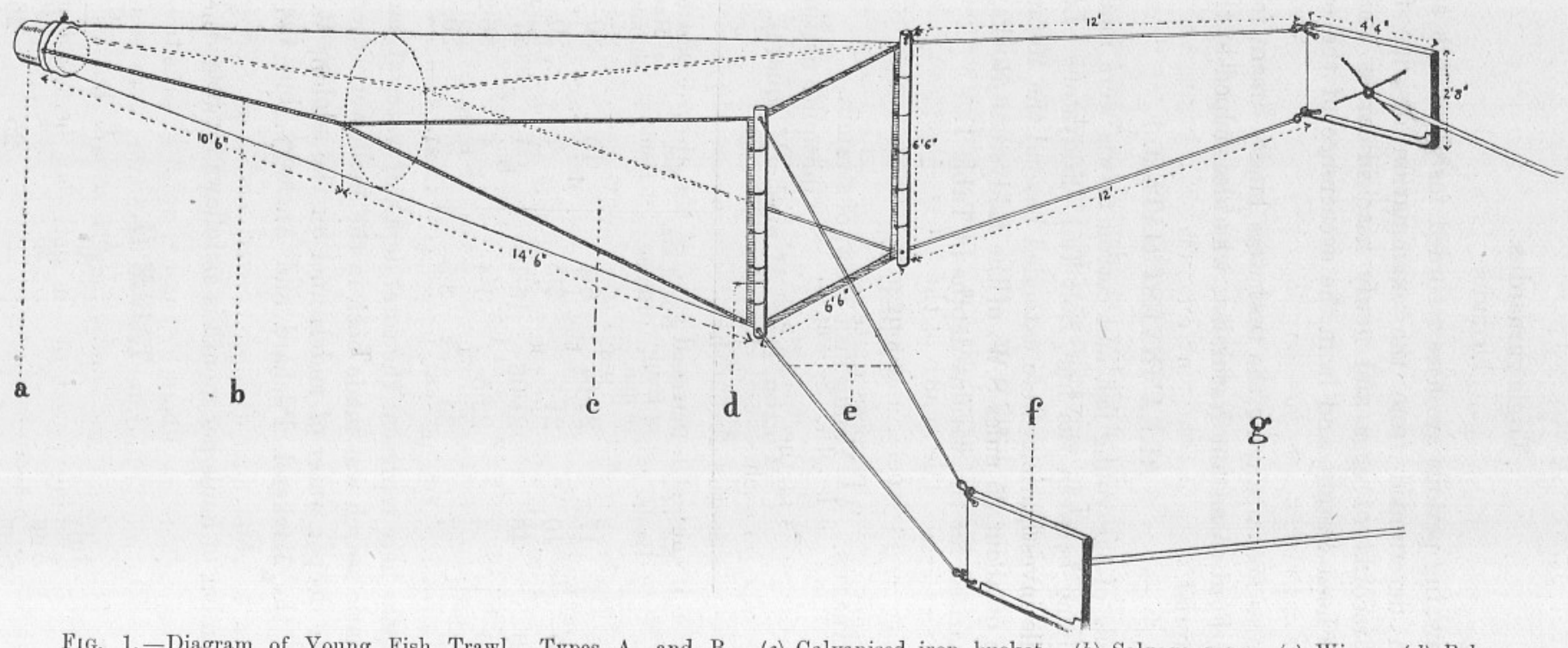

FIG. 1.-Diagram of Young Fish Trawl. Types A. and B. $(c)$ Galvanised iron bucket. $(b)$ Salvage rope. $(c)$ Wing. $(d)$ Pole.
$(e)$ Lanyard. $(f)$ Otter Board. $(g)$ Warp. Del. E. Ford. 


\section{Apparatus.}

Fig. 1 gives in diagrammatic form the type of young fish trawl as used in the Plymouth investigations. It is a modified form of Dr. C. G. J. Petersen's Yngel-trawl, a description and figure of which are published by Dr. Johs Schmidt in "Skrifter udgivne af Kommissionen for Havundersogelser," No. 1, 1904, p. 36. The dimensions given in Fig. 1 are those which were taken from the nets in use.

On the Oithona, a single warp with two bridles, each 20 fathoms in length, is led from the winch over a series of roller blocks along the port side and over a roller on the port quarter. The bridles are shackled to Otter Boards, $3^{\prime}$ by $3^{\prime} 9^{\prime \prime}$. Two pairs of lanyards of $2^{\prime \prime}$ manilla rope connect the Otter Boards with two wooden poles which keep the mouth of the net open. The lanyards are $12^{\prime}$ in length and pass through drilled holes, one at the top and one at the bottom of each pole. A narrow strip of canvas about $6^{\prime \prime}$ in depth encircles the mouth of the net, the sides of which are lashed to the poles by separate lashings, rove through six eyelets. The mouth of the net is $6 \frac{1^{\prime}}{}{ }^{\prime}$ square. A rectangular opening with smaller poles and longer headline and foot rope has been found to answer the purpose quite as well. There are two triangular wings about $14 \frac{1}{2}^{\prime}$ in length. Salvage ropes of $\frac{1}{2}^{\prime \prime}$ to $\frac{3}{4}$ " manilla or hemp run along the sidềs of the wings and are continued to the "cod-end," as a single rope on each side of the net. These give greater strength to the net and are essential during the process of hauling on board the ship. The breadth of the net is reduced to $5^{\prime}$ at the apex of the wings and to $2^{\prime}$ at the cod-end. A galvanized iron bucket $1^{\prime}$ long by $8^{\prime \prime}$ in diameter is attached to the cod-end. This is more convenient for the transference of the catch and seems to reduce the liability of damage to the specimens. The strain is taken off the cod-end of the net by lashing the ends of the salvage ropes to two iron loops on the bucket, while the cod-end is also strengthened by the addition of a narrow strip of canvas covering.

The nets used in the present investigations are designated as Types $\mathrm{A}, \mathrm{B}$ and $\mathrm{C}$.

\section{TYPE A.}

This is a net made of the Danish material "Stramin," which is composed of threads of closely spun hemp yarn. Each thread is made up of two strands which have undergone considerable stretching and torsion, to give greater strength and to reduce to a minimum the teasing out of the fibres. There are about 12 meshes or 13 threads to an inch. The threads are woven over and under each other and there is no attempt at knotting. The meshes are approximately square, but are not uniform in size. The catching power of the net may be vitiated by the disintegration of the material. 


\section{TYPE B}

Type B is composed of fine cotton mosquito neuting. Two strands of fine cotton are twisted loosely along their whole length and the corners of the mesh are so arranged that single strands from the two adjacent sides of the "square" cross each other and bind the whole together. There is no knotting of the threads. The twisting of the strands and the tenacity of the fibres prevent to a great extent the " running " of the net when damaged. This material is much more elastic than stramin, and tends to pull more in one direction than in another. Care must be taken in the making of a net of this material so that the strain imposed on the net pulls the meshes out to a definite and open square formation. When stretched out in this way, there are 9 to 10 meshes to an inch.

\section{TYPE C.}

The apparatus designated as $\mathrm{C}$ is a cotton trawl, devised on similar lines to types $\mathrm{A}$ and $\mathrm{B}$ with a mesh of $\frac{1}{2}^{\prime \prime}$ diagonally from knot to knot. This is still in the experimental stage and further improvements are contemplated. Its effieiency, however, in securing the early bottom stages is well shown. To avoid confusion in the meaning of the mesh $\frac{1}{2}$ "net, it may also be described as a mesh of $\frac{1}{4}$ " between the knots along the square or 1 " all round. The cotton is 9 ply. This net was also " cutched."

The towing speed of Types A and B is generally from slow to halffrom 1 to $3 \mathrm{mls}$. per hour. This, however, depends largely on the tides and the condition of the sea. Against a strong flood or ebb tide the revolutions of the engine will naturally be increased to keep the net from sinking to the bottom. The fault of the net generally lies in the bulk of the poles, which set up a strong wash at its mouth, but this is difficult to obviate. The length of the net is probably sufficient to retain the young fish which are caught.

The depth at which the captures were made is designated in the Tables IX and X by the letters S. M. B. for surface, midwater and bottom hauls, intermediate hauls being shown as S.-M. (surface to midwater) and M.-B. (midwater to bottom). The depths have been estimated from the amount of warp used, from the speed of the vessel, and from the prevailing sea conditions. This method may be open to criticism, but in these comparatively shallow waters of the Channel the method adopted is the simplest and most convenient and seems to meet the case quite well.

The duration of the hauls is not quite uniform, as it is almost impossible to hit off an exact time limit. The mean is about 30 minutes.

The selective power of the nets is well shown, but the material used 
has not always been perfect. This has been the chief difficulty and is explained by the present-day conditions of trade.

\section{DETERMINATION OF THE MATERIAL.}

The catches of the young fish trawls were transferred to glass jars. A few of the more active fish were picked out and kept alive for special study. The remainder of the catch was immediately killed with a weak solution of formalin, to prevent the medusæ from making their customary depredations on the young fish. When time and conditions allowed, most of the fish were picked out on board ship. The whole of the material was handed over to Dr. Lebour for investigation of the food contents and she also identified the species, and recorded the measurements before cutting them up. The rarer fish and the Gurnards were kept intact and dealt with by the writer. Mr. Ford determined the Ammodytidæ (Sand eels).

The young fish have been determined by the use of existing literature, which is now fairly comprehensive. There are still many gaps to fill in and an accurate determination is essential before the broader biological problems can be tackled. Comprehensive collecting during a complete year has not been possible. There is much still to be done in the earlier and later months of the year before we can arrive at a complete story of the distribution and numbers of young fish near Plymouth. The measurements of the young fish have been recorded to the nearest half millimetre. Here, as always, the length is the total length-tip of snout to tip of caudal fin.

\section{POST-LARVAL CHARACTERS.}

The peculiar structures of the post-larval young of Teleosteans have often enough been described, vide Regan, 1916, and Fage, 1918. In most cases the young are so markedly different in the pelagic stage from the adult that the characters so well known for the determination of the latter are often of little use for the identification of the former. Generally, the structure and shape of the young are adapted to their particular mode of life and are " oriented by hereditary factors." The pelagic life is móre or less transitory, in some it is of short duration, in others long. A long larval or post-larval life is generally associated with deeper water spawners e.g. Conger vulgaris ; a short pelagic existence with coastal spawners, e.g. Gadus luscus. This must be accepted, however, with modification.

The surest determination of a species is to be found in the counting of the vertebræ and fin rays (if these be developed), and this method has been adopted in all doubtful cases. 


\section{NUMERICAL RESULTS.}

The following data have been compiled to show roughly the comparison in the seasonal distribution of the numbers of young fish caught with the young fish trawl (Types A and B) during the months July, August and September for the years 1913, 1914 and 1919. It must be understood, however, that the comparisons are by no means conclusive owing to the fact, which Dr. Allen (1917) has already pointed out, that no two nets have the same catching power and that the number of hauls at the different depths is far from being uniform either in actual numbers or in the duration of each haul. Still, the data at disposal justify some consideration.

\section{TABLE III.}

Apparatus A and B. Period: July only.

$\begin{array}{cccccc}\begin{array}{c}\text { Year. } \\ \text { (July.) }\end{array} & \begin{array}{c}\text { Total } \\ \text { number } \\ \text { of young } \\ \text { fish. }\end{array} & \begin{array}{c}\text { Total } \\ \text { number } \\ \text { of hours, } \\ \text { fishing. }\end{array} & \begin{array}{c}\text { number } \\ \text { of fish } \\ \text { per hour. }\end{array} & \begin{array}{c}\text { Total } \\ \text { number } \\ \text { of hauls. }\end{array} & \begin{array}{c}\text { Average } \\ \text { number } \\ \text { of fish } \\ \text { per haul. }\end{array} \\ 1913 & 1206 & 9 \cdot 8 & 123 & 29 & 41 \\ 1914 & 1885 & 12 \cdot 6 & 149 & 38 & 49 \\ 1919 & 4214 & 11 \cdot 6 & 363 & 30 & 140\end{array}$

The hauls, Table III, were distributed over the various depths as shown in Table IV, wher the depths represent the total depth of water at the particular localicies.

TABLE IV.

Apparatus A and B.

$\begin{array}{ccccc}\text { Depth in fathoms } & \begin{array}{c}0-10 \\ \text { Number of } \\ \text { hauls. }\end{array} & \begin{array}{c}10-20 \\ \text { Number of } \\ \text { hauls. }\end{array} & \begin{array}{c}20-30 \\ \text { Number of } \\ \text { hauls. }\end{array} & \begin{array}{c}\text { Number of } \\ \text { hauls. }\end{array} \\ 1913 & 9 & 5 & 14 & 1 \\ 1914 & 9 & 5 & 14 & 11 \\ 1919 & 1 & 4 & 21 & 4\end{array}$

Table III gives a general summary for July month. This month has been selected as investigations practically ceased after that month in

- 1914, and because in July, 1919, Type A net was used solely, being replaced in August by Type B. The average duration in minutes per haul in July for each year was 20.3 for 1913, 20 for 1914, and 23.5 for 1919.

Comparative Results for years 1913 and 1919 for hauls taken between the 20 and 30 fathom lines. 
The area of intensive fishing lies between the 20 and 30 fathom lines, and the same conclusion with regard to the numbers of young for the months July, August and September for the years 1913 and 1919 still holds good. They are much more numerous in 1919.

\section{TABLE V.}

Apparatus A and B. Period: July, August, September.

$\begin{array}{rcccc}\text { Year. } & \begin{array}{c}\text { Total number } \\ \text { of hauls. }\end{array} & \begin{array}{c}\text { Total number } \\ \text { of specimens. }\end{array} & \begin{array}{c}\text { Number of } \\ \text { hours' fishing. }\end{array} & \begin{array}{c}\text { A verage number } \\ \text { of fish per hour. }\end{array} \\ 1913 & 74 & 2137 & 26 \cdot 1 & 81 \\ 1919 & 48 & 5543 & 18 \cdot 08 & 306\end{array}$

Frequency in numbers of the more abundant young fish is shown in the following list, where the figures represent the number of fish per hour's fishing in the hauls taken between the 20 and 30 fathom contour lines.

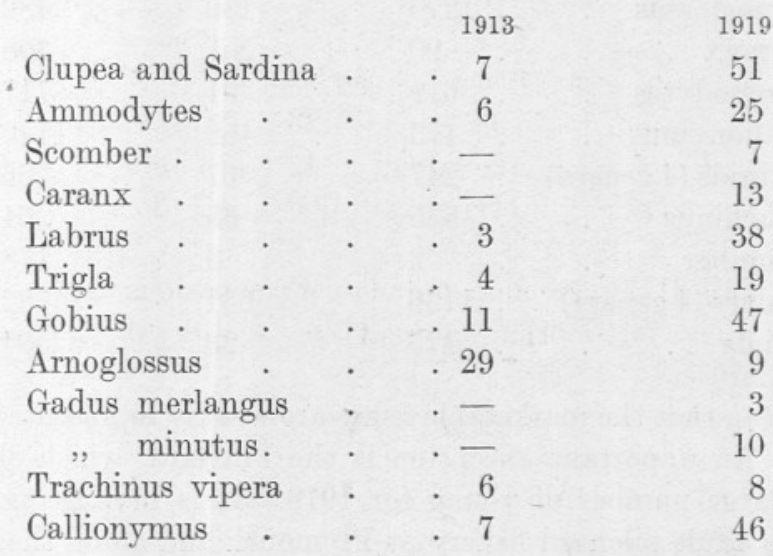

CoMPARISON in total captures for years 1913, 1914 and 1919 for the rnonths July, August and September.

\section{TABLE VI.}

Apparatus A and B.

$\begin{array}{cccccc}\text { Year. } & \begin{array}{c}\text { Total } \\ \text { number } \\ \text { of } \\ \text { fish. }\end{array} & \begin{array}{c}\text { Total } \\ \text { number } \\ \text { of honrs' } \\ \text { fishing. }\end{array} & \begin{array}{c}\text { Average } \\ \text { number } \\ \text { of fish } \\ \text { per hour. }\end{array} & \begin{array}{c}\text { Total } \\ \text { number } \\ \text { of } \\ \text { hauls. }\end{array} & \begin{array}{c}\text { Average } \\ \text { number } \\ \text { of fish } \\ \text { per haul. }\end{array} \\ 1913 & 5266 & 55 \cdot 5 & 94 & 160 & 32 \\ 1914 & 1908 & 13 \cdot 7 & 139 & 41 & 46 \\ 1919 & 11669 & 31 \cdot 08 & 375 & 84 & 138\end{array}$


Table VI gives a comparison between the three years for July, August and September. The average duration per haul being 20.8 minutes in $1913,20 \cdot 2$ in 1914 and 23.5 in 1919 . In 1914 only two hauls were made in August and one in September.

The greater abundance of young fish in 1919 is very striking. This may be due to many causes, among which are :-

(a) The greater selective power of the nets used in 1919.

(b) 1919 being a year of greater production of the young.

(c) 1919 being a later spawning year for some of the species as shown for the Mackerel.

The more abundant types are represented in the following list, where the numbers are the total number of fish captured during the same period-July to September (inclusive) for all the hauls of nets A and B.

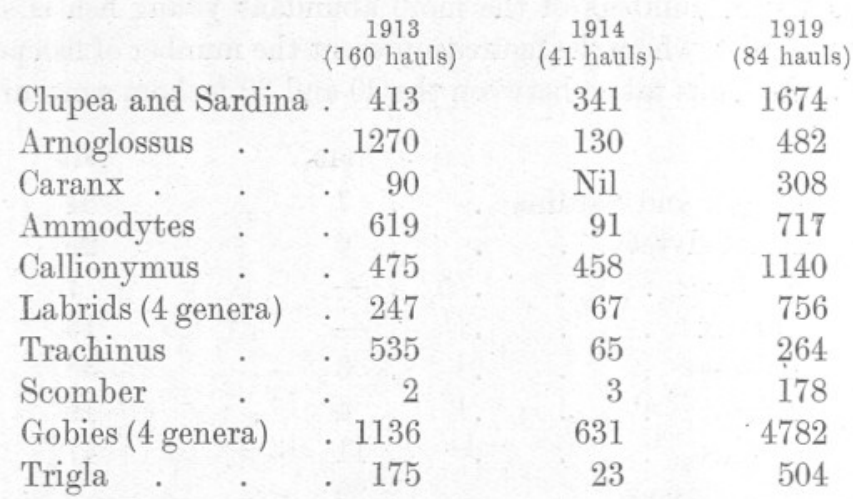

It will be seen that the marketable fishes are weakly represented during this period. An important exception is the Pilchard, which shows an abnormally large number of young for 1919. It is interesting also to note that the adult pilchard fishery at Plymouth and along the Cornish coast during the latter part of 1919 was the richest experienced for over twenty years.

The larger number of Mackerel in 1919 may be attributed to a year of later spawning. The years 1914 and 1919 showed an equal number of the young of this species-those in 1914 appearing in greatest numbers in June month. On the other hand, Arnoglossus (Scaldback) and Trachinus (Weever) were relatively most abundant in 1913.

\section{PRODUCTIVE HAULS.}

An interesting feature of the 1919 captures is the large proportion of hauls with nets $\mathrm{A}$ and $\mathrm{B}$ which are rich both in the number of species and of specimens. The hauls which show the highest percentage of species 
and of specimens were taken in greater numbers in localities where the total depth of water exceeded 20 fathoms, and where one would naturally expect a mixture of the young of inshore and offshore spawners, but there is also in these deeper waters an influx of forms which undoubtedly have drifted with the general up-channel current from the west. The following list shows a few of these rich hauls :-

\section{TABLE VIII.}

\section{Apparatus A and B.}

$\begin{array}{ccccc}\begin{array}{c}\text { No. of } \\ \text { haul. }\end{array} & \begin{array}{c}\text { Duration of haul } \\ \text { in minutes. }\end{array} & \begin{array}{c}\text { Total depth } \\ \text { in fathoms. }\end{array} & \begin{array}{c}\text { No of species } \\ \text { in haul. }\end{array} & \begin{array}{c}\text { No of specimens } \\ \text { in haul. }\end{array} \\ 2 & 30 & 16 & 16 & 148 \\ 6 & 30 & 12 & 16 & 166 \\ 9 & 30 & 29 & 17 & 399 \\ 11 & 25 & 26 & 19 & 288 \\ 12 & 25 & 26 & 23 & 272 \\ 13 & 20 & 26 & 17 & 203 \\ 14 & 20 & 27 & 14 & 432 \\ 28 & 30 & 28 & 23 & 316 \\ 62 & 30 & 41 & 15 & 268 \\ 64 & 30 & 41 & 12 & 368 \\ 66 & 30 & 41 & 14 & 264 \\ 77 & 30 & 4-7 & 12 & 2320 \text { (2269 are } \\ & & & & \text { one species) }\end{array}$

\section{EXPLANATION OF CHART AREAS AND POSITIONS.}

The Chart Area of each haul in Tables IX and X is that shown in the Chart published in Vol. X, No. 2, June, 1914. The positions have been calculated from cross-bearings. For convenience in estimating the locality of each haul, the nearest observed point is shown in Tables IX and $\mathrm{X}$ as bearing a definite magnetic direction and a fixed distance from the actual position of the haul.

The localities of Hauls 62 to 68 (inclusive) for nets A and B and Hauls 7 to 16 (inclusive) for net $\mathrm{C}$ were determined from astronomical "fixes," which were kindly taken for the writer by Mr. E. W. Nelson. 
List of Stations. Apparatus A.

Explanation. S. $=$ surface. M. $=$ midwater. $\mathrm{B} .=$ bottom. N.H. =Night Haul.

\begin{tabular}{|c|c|c|c|c|c|c|}
\hline $\begin{array}{c}\text { No. of } \\
\text { Haul. }\end{array}$ & Date. & $\begin{array}{c}\text { Depth } \\
\text { of } \\
\text { Haul. }\end{array}$ & $\begin{array}{l}\text { Duration } \\
\text { of Haul } \\
\text { in } \\
\text { minutes. }\end{array}$ & Locality. & & $\begin{array}{l}\text { Total } \\
\text { Depth } \\
\text { in } \\
\text { fathoms. }\end{array}$ \\
\hline 1 & 3.vii.19 & B. & 20 & Rame Penlee & . & 7 \\
\hline 2 & 7.vii.19 & B. & 30 & Rame N. $37^{\circ}$ W. $1 \frac{1}{4}$ miles & . & 15 \\
\hline 3 & 9.vii.19 & M. & 25 & Eddystone E.N.E. 6 miles & . & 36 \\
\hline 4 & 10.vii.19 & B. & 90 & 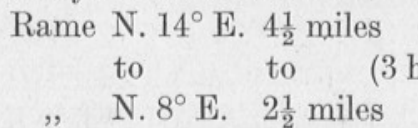 & auls) & $\left.\begin{array}{l}28 \\
\text { to } \\
26\end{array}\right\}$ \\
\hline 5 & 11.vii.19 & B. & 30 & Rame N. $5^{\circ}$ E. $1 \frac{3}{4}$ miles & . & 24 \\
\hline 6 & 18.vii.19 & M. - B. & 30 & Penlee N. $9^{\circ}$ W. $\frac{3}{4}$ mile & . & 12 \\
\hline 7 & 18.vii.19 & M.-B. & 25 & Penlee N. $10^{\circ}$ E. $2 \frac{1}{4}$ miles & . & 24 \\
\hline 8 & 18.vii.19 & M. - B. & 20 & Rame N. $2^{\circ}$ W. $3 \frac{1}{4}$ miles & . & 27 \\
\hline 9 & 18.vii.19 & M. -B. & 30 & Rame N. $5^{\circ}$ E. $4 \frac{1}{2}$ miles & . & 29 \\
\hline 10 & 21.vii.19 & B. & 20 & Rame E.N.E. 2 miles . & . & 25 \\
\hline 11 & 21.vii.19 & B. & 25 & Rame E. by N. $2 \frac{3}{4}$ miles & . & 26 \\
\hline 12 & 21.vii.19 & B. & 25 & Rame E. $\frac{1}{2}$ N. 4 miles . & . & 26 \\
\hline 13 & 21.vii.19 & B. & 20 & Rame E. $\frac{1}{4}$ N. $5 \frac{1}{4}$ miles . & . & 26 \\
\hline 14 & 24.vii.19 & M. & 20 & Rame E. $\frac{3}{4}$ N. $4 \frac{1}{2}$ miles . & . & 27 \\
\hline 15 & 24.vii. 19 & S. & 25 & Looe N. $15^{\circ}$ W. 2 miles & . & 10 \\
\hline 16 & 24.vii.19 & M. & 20 & Looe N. $3^{\circ} \mathrm{W}, 4$ miles , & , & 25 \\
\hline
\end{tabular}




\begin{tabular}{|c|c|c|c|c|c|c|}
\hline $\begin{array}{l}\text { No. of } \\
\text { Haul. }\end{array}$ & Date. & $\begin{array}{c}\text { Depth } \\
\text { of } \\
\text { Haul. }\end{array}$ & $\begin{array}{c}\text { Duration } \\
\text { of Haul } \\
\text { in } \\
\text { minutes. }\end{array}$ & Locality. & $\begin{array}{c}\text { Total } \\
\text { Depth } \\
\text { in } \\
\text { fathoms. }\end{array}$ & $\begin{array}{l}\text { Chart } \\
\text { Area. }\end{array}$ \\
\hline 17 & 28.vii.19 & M. & 20 & Penlee N. $23^{\circ}$ E. $\frac{3}{4}$ mile & 13 & T. \\
\hline 18 & 28.vii.19 & M.-B. & 20 & Rame N. $1 \frac{1}{2}$ miles & 24 & T. \\
\hline 19 & 28.vii.19 & M. & 20 & Rame N.N.E. $2 \frac{1}{2}$ miles . & 27 & $\mathrm{~T}$. \\
\hline 20 & 29.vii.19 & B. & 20 & Mewstone N.E. $1 \frac{1}{4}$ miles & 22 & W. \\
\hline 21 & 29.vii.19 & B. & 20 & Mewstone N: $1_{4}^{1}$ miles & 20 & W. \\
\hline 22 & 29.vii.19 & M. & 20 & Mewstone N. $\frac{1}{2}$ E. $4 \frac{1}{4}$ miles & 25 & $\mathrm{X}$. \\
\hline 23 & 29.vii.19 & S. & 20 & Mewstone N. $4 \frac{1}{2}$ miles . & 24 & $\mathrm{X}$. \\
\hline 24 & 29.vii.19 & B. & 20 & Eddystone N. $70^{\circ}$ W. $7 \frac{1}{4}$ mile & 32 & $\mathrm{X}$. \\
\hline 25 & 29.vii.19 & B. & 20 & Eddystone N. $64^{\circ}$ W. $7 \frac{1}{2}$ mile & 33 & $\mathrm{X}$. \\
\hline 26 & 29.vii.19 & B. & 20 & Bolt Tail E.N.E. $7 \frac{1}{4}$ miles & 33 & $\mathrm{Z}$. \\
\hline 27 & 31.vii.19 & S. & 20 & Rame N. by W. $5 \frac{1}{2}$ miles & 29 & $\mathrm{X}$. \\
\hline 28 & 31.vii.19 & B. & 30 & Rame N. $13^{\circ}$ W. $4_{4}^{3}$ miles & 28 & $\mathrm{X}$ \\
\hline 29 & 1.viii.19 & B. & 20 & Rame E. $\frac{1}{2}$ N. 1 mile & 16 & $\mathrm{~T}$. \\
\hline 30 & 1.viii.19 & B. & 20 & Rame N. $62^{\circ}$ E. $2 \frac{1}{2}$ miles & 26 & T. \\
\hline 31 & 1.viii.19 & B. & 20 & Rame N. $60^{\circ}$ E. $3 \frac{1}{2}$ miles & 27 & T. \\
\hline 32 & 1.viii.19 & S. & 20 & Rame N. $55^{\circ}$ E. $4 \frac{1}{4}$ miles & 28 & $\mathrm{~T}$. \\
\hline 33 & 5.viii.19 & M. & 20 & Penlee N. $3^{\circ}$ W. $1 \frac{1}{4}$ miles & 15 & $\mathrm{~T}$. \\
\hline 34 & 5.viii.19 & B. & 20 & Penlee N. $2^{\circ}$ E. 4 miles. & 27 & W. \\
\hline 35 & 5.viii.19 & B. & 20 & 1 Eddystone S. $66^{\circ}$ W. $4 \frac{1}{2}$ miles & 29 & $\mathrm{~S}$. \\
\hline 36 & 5.viii.19 & S. & 20 & Eddystone W. by S. 3 miles & 30 & S. \\
\hline 37 & 5.viii.19 & B. & 20 & Eddystone S. $71^{\circ}$ W. $2 \frac{3}{4}$ miles & 30 & S. \\
\hline 38 & 5.viii.19 & M. & 20 & Eddystone S. $59^{\circ}$ W. $3 \frac{1}{4}$ miles & 30 & S. \\
\hline 39 & 5.viii.19 & B. & 25 & Rame N. $14^{\circ}$ E. $3 \frac{3}{4}$ miles & 28 & S. \\
\hline
\end{tabular}




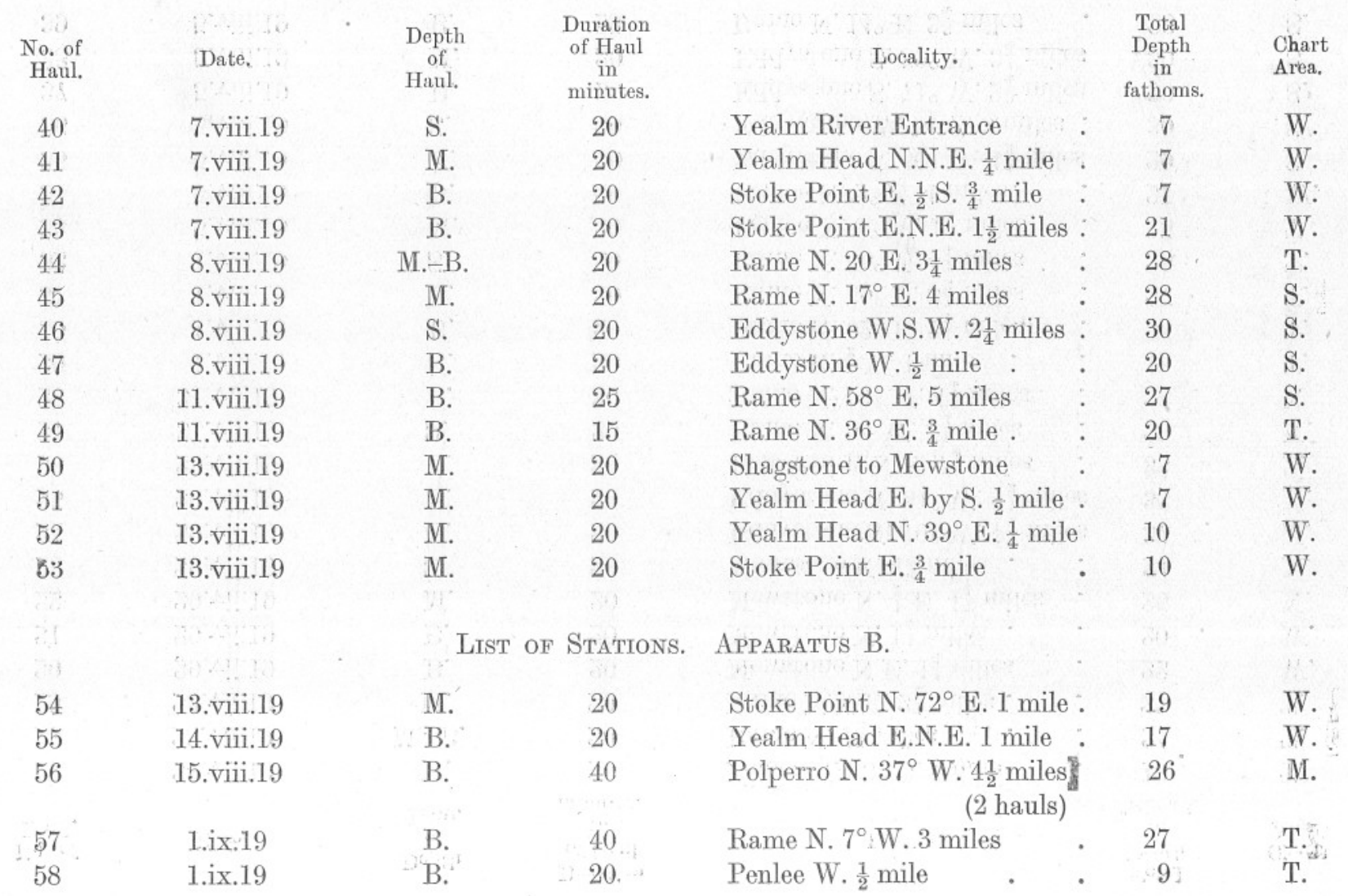




\begin{tabular}{|c|c|c|c|c|c|c|}
\hline $\begin{array}{l}\text { No., of } \\
\text { Haul. }\end{array}$ & Date. & $\begin{array}{l}\text { Depth } \\
\text { of } \\
\text { Haul. }\end{array}$ & $\begin{array}{l}\text { Duration } \\
\text { of Haul } \\
\text { in } \\
\text { minutes. }\end{array}$ & Locality. & $\begin{array}{l}\text { Total } \\
\text { Depth } \\
\text { in } \\
\text { fathoms. } \\
\end{array}$ & $\begin{array}{l}\text { Chart } \\
\text { Area. }\end{array}$ \\
\hline 59 & 3.ix.19 & S. & 20 & Rame E. $3 \frac{1}{2}$ miles & 24 & T. \\
\hline 60 & 3.ix.19 & M. & 20 & Rame E. $4 \frac{1}{2}$ miles & 26 & T.M. \\
\hline 61 & 3.ix.19 & B. & 20 & Rame E. 5 miles. & 26 & M. \\
\hline 62 & 9.ix.19 & S. & 30 & $50^{\circ} 0^{\prime} \cdot 5$ N. $4^{\circ} 35^{\prime}$ W. N.H. . & 41 & - \\
\hline 63 & 9.ix.19 & M. & 30 & $50^{\circ} 0^{\prime} \cdot 25$ N. $4^{\circ} 34 \cdot 8$ W. N.H. & 41 & - \\
\hline 64 & $9 . \mathrm{ix} .19$ & B. & 30 & $50^{\circ}$ N. $4^{\circ} 34^{\prime} \cdot 7$ W. N.H. & 41 & - \\
\hline 65 & 9.ix.19 & S. & 30 & $49^{\circ} 59^{\prime} \cdot 7$ N. $4^{\circ} 34^{\prime} .5$ W. N.H. & 41 & - \\
\hline 66 & $9.1 \times .19$ & B. & 30 & $49^{\circ} 59^{\prime} \cdot 5$ N. $4^{\circ} 34^{\prime} \cdot 6$ W. N.H. & 41 & - \\
\hline 67 & 10.ix.19 & S. & 30 & $49^{\circ} 58^{\prime} .5$ N. $4^{\circ} 25^{\prime} \cdot 2$ W. N.H. & 41 & - \\
\hline 68 & 10.ix.19 & M. & 30 & $49^{\circ} 59^{\prime} \cdot 5$ N. $4^{\circ} 24^{\prime} .5$ W. N.H. & -41 & - \\
\hline 69 & 17.ix.19 & B. & 30 & Eddystone S. by W. $1 \frac{1}{2}$ miles. & 31 & S. \\
\hline 70 & 17.ix.19 & B. & 20 & Eddystone S. $2 \frac{1}{2}$ miles & 30 & S. \\
\hline 71 & 17.ix.19 & B. & 25 & Eddystone S. by E. $3 \frac{1}{2}$ miles : & 29 & S. \\
\hline 72 & 17.ix.19 & B. & 30 & Eddystone S. $3^{\circ}$ E. $3 \frac{1}{4}$ miles : & 29 & S. \\
\hline 73 & 17.ix.19 & B. & 30 & Rame N. $55^{\circ}$ E. $2 \frac{3}{4}$ miles & 29 & $\mathrm{~T}$ \\
\hline 74 & 19.ix.19 & B. & 20 & Whitsand Bay E. . & 5 & T.U. \\
\hline 75 & 19.ix.19 & M. . & 20 & Rame Penlee . & 7 & T. \\
\hline 76 & 25.ix.19 & B. & 30 & Cawsand Bay & $4-7$ & T.U. \\
\hline 77 & 25.ix.19 & B. & 30 & Cawsand Bay . . & $4-7$ & T.U. \\
\hline 78 & 25.ix.19 & B. & 20 & West Channel (Sound) & 7 & T.V.W. \\
\hline 79 & 25.ix.19 & M.-B. & 40 & West Channel . & 7 & T.V.W. \\
\hline 80 & 25.ix.19 & M.-B. & 20 & West Channel . & 7 & T.V.W. \\
\hline 81 & 29.ix.19 & B. & 20 & Rame N. $58^{\circ}$ E. 5 miles & 27 & S. \\
\hline
\end{tabular}


TABLE X.

List of Stations. Apparatus C.

No. of
Haul.
1
2
3
4
5
6
7
8
9
10
11
12
13
14
15
16
17
18

\begin{tabular}{|c|c|c|}
\hline Date. & $\begin{array}{l}\text { Depth } \\
\text { of } \\
\text { Capture. }\end{array}$ & $\begin{array}{c}\text { Duration } \\
\text { of Haul } \\
\text { in minutes. }\end{array}$ \\
\hline 19 Aug. 19 & S. - M. & 20 \\
\hline ", & S. $-M$. & 20 \\
\hline, & M. & 20 \\
\hline 25 Aug. 19 & B. & 40 \\
\hline 26 Aug. 19 & B. & 24 \\
\hline 3 Sept. 19 & B. & 20 \\
\hline 8 Sept. 19 & S. & 55 \\
\hline , & M. & 30 \\
\hline , & B. & 30 \\
\hline ", & S. & 30 \\
\hline 9 Sept. 19 & B. & 30 \\
\hline " & M. & 30 \\
\hline " & M.-B. & 30 \\
\hline$"$ & S.-M. & 30 \\
\hline " & M.-B. & 30 \\
\hline 10 Sept. 19 & S. & 30 \\
\hline 12 Sep̀t. 19 & B. & 30 \\
\hline " & B. & 30 \\
\hline
\end{tabular}

\begin{tabular}{|c|c|c|}
\hline Locality. & $\begin{array}{c}\text { Total } \\
\text { depth in } \\
\text { fathoms. }\end{array}$ & $\begin{array}{l}\text { Chart } \\
\text { Area. }\end{array}$ \\
\hline Plymouth Sound (White Patch) & 6 & V. \\
\hline Cawsand Bay (Zostera) & $4-7$ & T.U. \\
\hline ", & $4-7$ & T.U. \\
\hline , & $4-7$ & T.U. \\
\hline , , , & $4-7$ & T.U. \\
\hline Rame E. 5 miles . & 27 & M. \\
\hline $50^{\circ} 02^{\prime} \cdot 3$ N. $4^{\circ} 35^{\prime} \cdot 5$ W. N.H. & 40 & - \\
\hline $50^{\circ} 01^{\prime} \cdot 7$ N. $4^{\circ} 35^{\prime} \cdot 4$ W. N.H. & 40 & - \\
\hline $50^{\circ} 01^{\prime} \cdot 3 \mathrm{~N} .4^{\circ} 35^{\prime} \cdot 2 \mathrm{~W}$. N.H. & 40 & - \\
\hline $50^{\circ} 00^{\prime} \cdot 8$ N. $4^{\circ} 35^{\prime}$ W. N.H. . & 40 & - \\
\hline $49^{\circ} 49^{\prime}$ N. $4^{\circ} 28^{\prime} \cdot 5$ W. N.H. . & 43 & - \\
\hline $49^{\circ} 50^{\prime} \cdot 6$ N. $4^{\circ} 28^{\prime}$ W. N.H. . & 43 & - \\
\hline $49^{\circ} 52^{\prime}$ N. $4^{\circ} 27^{\prime} \cdot 5$ W. N.H. & 43 & - \\
\hline $49^{\circ} 54^{\prime}$ N. $4^{\circ} 26^{\prime} \cdot 8$ W. N.H. . & 44 & - \\
\hline $49^{\circ} 56^{\prime}$ N. $4^{\circ} 26^{\prime}$ W. N.H. & 42 & - \\
\hline $50^{\circ} 00^{\prime} \cdot 5$ N. $4^{\circ} 23^{\prime} \cdot 5$ W. N.H. & 41 & - \\
\hline Mewstone N. $53^{\circ}$ E. 3 miles . & 26 & W. \\
\hline Rame N. $48^{\circ}$ E. $1 \frac{1}{2}$ miles & 30 & $\mathrm{~T}$. \\
\hline
\end{tabular}




\begin{tabular}{|c|c|c|c|c|c|c|c|c|}
\hline $\begin{array}{c}\text { No. } \\
\text { of } \\
\text { Haul. }\end{array}$ & Date. & $\begin{array}{c}\text { Depth } \\
\text { of } \\
\text { Capture. }\end{array}$ & $\begin{array}{c}\text { Duration } \\
\text { of Haul } \\
\text { in minutes. }\end{array}$ & Locality. & & & $\begin{array}{c}\text { Total } \\
\text { depth in } \\
\text { fathoms. }\end{array}$ & $\begin{array}{l}\text { Chart } \\
\text { Area. }\end{array}$ \\
\hline 19 & 16 Sept. 19 & M. & 25 & Whitsand Bay E. & . & & $4-5$ & T.U. \\
\hline 20 &, & B. & 25 &,, & . & & $4-5$ & T.U. \\
\hline 21 & , & B. & $25 \cdot$ &,, & . & & $4-5$ & T.U. \\
\hline 22 & " & B. & 30 & , , & . & & $4-5$ & T.U. \\
\hline 23 & ", & B. & 30 & , , , & . & & $4-5$ & T.U. \\
\hline 24 & 18 Sept. 19 & B. & 45 & " " & . & & $5-6$ & $\mathrm{~T}$. \\
\hline 25 & , & B. & 45 & ", , & . & & $5-6$ & $\mathrm{~T}$. \\
\hline 26 & 23 Sept. 19 & B. & 20 & Cawsand Bay (Zostera) & & & $4-7$ & T.U. \\
\hline 27 & , & B. & 25 &,$\quad$, & . & & $4-7$ & T.U. \\
\hline 28 & 29 Sept. 19 & $\mathrm{~B}$ & 10 & Whitsand Bay E. & . & & $6-10$ & $\mathrm{~T}$ \\
\hline 29 & , & B. & 10 & Rame E.S.E. $2 \frac{1}{2}$ miles & . & & 15 & $\mathrm{~T}$. \\
\hline 30 & " & B. & 30 & Rame E. by S. 3 miles & . & & 19 & $\mathrm{~T}$. \\
\hline 31 & , & B. & 30 & Rame E.N.E. 4 miles & . & & 27 & T. \\
\hline
\end{tabular}




\title{
ISOSPONDYLI.
}

\section{CLUPEID $A$.}

\author{
Clupea sprattus L. \\ Sprat. \\ , HARENGUS L. \\ HERRING. \\ Sardina (Clupea) pilchardus (Walb.) Pilchard.
}

The young fry of the Clupeidæ are produced in very large numbers in the neighbourhood of Plymouth, and these belong to three species, Clupea harengus (Herring), Clupea sprattus (Sprat) and Sardina pilchardus (Pilchard). Alosa alosa (Shad) occurs not uncommonly in the adult stage in the estuaries, as for instance at Saltash, where they are caught in tuck nets in autumn, but their young stages appear to have escaped notice.

The spawning period at Plymouth for the three species shows a good deal of overlap, but the maximum spawning months for each of the three appear to be more distinct.

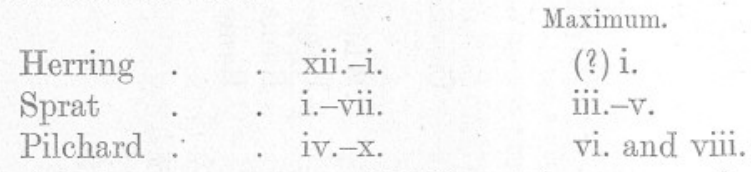

The 1919 material shows a capture of 1674 post-larvæ-nearly all of which are Pilchard, with an average of about 20 specimens per haul estimated for the three months. These occurred in 66 hauls, an average of 51 specimens per hour's fishing for the three months' period.

\section{Clupea sprattus L. Sprat.}

Apparatus A and B.

$\begin{array}{cccccc}\text { Month. } & \begin{array}{c}\text { Total No. } \\ \text { of Hauls. }\end{array} & \begin{array}{c}\text { No. of Hauls } \\ \text { in which } \\ \text { species } \\ \text { occurs. }\end{array} & \begin{array}{c}\text { No. of } \\ \text { specimens. }\end{array} & \begin{array}{c}\text { Size in } \\ \text { mm. }\end{array} & \begin{array}{c}\text { Average } \\ \text { No. per } \\ \text { haul. }\end{array} \\ \text { July } & 30 & 11 & 57 & 13-27 & 1 \cdot 9 \\ \text { Aug. } & 29 & 5 & 19 & 18-25 & 0 \cdot 6\end{array}$

Few post-larvæ of the Sprat occurred so late in the year-all those recorded being still in the "nude" stage. The larger "vêtu" (scaled) and "silvery" types from about 30 to $60 \mathrm{~mm}$. (or more) were found in large shoals mixed with Herring in July in the rock pools below the Laboratory, the largest of those being probably about six months old. The distribution of the post-larvæ is general, specimens occurring outside the Eddystone, though they are more frequent closer inshore. 


\title{
Sardina (Clupea) PILChardus (Walb.).
}

\author{
Apparatus A and B.
}

$\begin{array}{cccccc}\text { Month. } & \begin{array}{c}\text { Total No. } \\ \text { of Hauls. }\end{array} & \begin{array}{c}\text { No. of Hauls } \\ \text { in which } \\ \text { species } \\ \text { occurs. }\end{array} & \begin{array}{c}\text { No. of } \\ \text { specimens. }\end{array} & \begin{array}{c}\text { Size in } \\ \text { mm. }\end{array} & \begin{array}{c}\text { Average } \\ \text { No. per } \\ \text { haul. }\end{array} \\ \text { July } & 30 & 23 & 528 & 6-26 & 17 \cdot 6 \\ \text { Aug. } & 29 & 19 & 521 & 8-25 & 17 \cdot 9 \\ \text { Sept. } & 25 & 19 & 471 & 9-28 \cdot 5 & 18 \cdot 8\end{array}$

The number of post-larval pilchards is large. For the whole period of three months, the number of hours' fishing totalled $31 \cdot 08$, so that the average number of specimens for one hour's fishing of the young fish trawls A and B works out at about 48 .

In the cotton trawl C, 146 specimens (13-28 mm.) were secured in 10 hauls in August and September, an average of $4 \cdot 7$ specimens per haul for a total of 31 hauls. The larger size of the mesh of this net accounts for the small numbers - those which were captured being generally twisted round the "meshing." The prime object of this net was to catch the larger " poutines vêtues " and " palailles" stages (Marion, 1888, Pouchet, 1888) from 40 to $70 \mathrm{~mm}$. and systematic investigations were carried out both in the shallower water of the bays and in the deeper midchanne] water. Both localities, however, gave negative results during August and September months. This negative result, however, is probably not the real state of things, and two important factors have to be considered in (1) the catching power of the net and (2) in the ability of the young to escape the net.

The "poutines nues" - all the above records belong to this stageare exceedingly abundant, having been taken over the whole of the area investigated from the Sound out to and beyond the 40 -fathom line. Cunningham (1893) was the first to record captures from brackish water at Saltash, while this year (October) a few were taken by Dr. J. H. Orton in Millbay dry dock. The "nude" stage probably exceeds $40 \mathrm{~mm}$. when there is a reduction in length in the change to the "poutines vêtues." The "palailles" or Sardine stage, with the scales larger and giving the fish its silvery appearance, have been taken at end of October and in November. The writer has the following three records :-

(1) One specimen, $90 \mathrm{~mm}$. (snout to tip of caudal), secured by hand in a rock pool at entrance to Millbay Docks on 29th October, 1919. This was caught by W. Searle, of the Laboratory. 
(2) One specimen, $72 \mathrm{~mm}$. (snout to tip of caudal), from stomach of Gadus virens landed at Newlyn on 17 th November, 1913. This specimen was sent to the Laboratory by Mr. Matthias Dunn.

(3) One specimen, $69 \mathrm{~mm}$. (snout to tip of caudal) from mouth of Zeus faber landed on quay at Mevagissey on 18th November, 1913, and sent to the Laboratory by Mr. Howard Dunn.

The two smallest specimens are probably the young of the same year, and the largest probably spawned in October of the previous year and thus one year old (cf. Cunningham, 1891, 1899, 1900 ; Hjort, 1913 ; and Fage, 1913).

\section{TABLE XI.}

Apparatus A. and B.

Record of Clupea and Sardina.

\begin{tabular}{|c|c|c|c|c|c|c|c|c|}
\hline $\begin{array}{l}\text { No. of } \\
\text { Haul. }\end{array}$ & Date. & Depth. & $\begin{array}{r}C . \\
\text { No. }\end{array}$ & $\begin{array}{l}\text { prattus. } \\
\text { ize in } \mathrm{mm} .\end{array}$ & $\begin{array}{l}\text { S. } p \\
\text { No. }\end{array}$ & $\begin{array}{l}\text { chardus. } \\
\text { ze in mm. }\end{array}$ & No. & $\begin{array}{l}\text { C. } s p . \\
\text { Size in } \mathrm{mm}\end{array}$ \\
\hline 1 & 3.vii.19 & B. & 2 & $13-18$ & - & 一 & - & - \\
\hline 2 & 7.vii. 19 & B. & 6 & $18-23$ & 83 & $12-25$ & - & - \\
\hline 3 & 9.vii.19 & M. & 3 & $16 \cdot 5-20$ & 26 & $12-17$ & - & - \\
\hline 4 & 10.vii.19 & B. & 1 & 18 & 2 & $14-20$ & - & - \\
\hline 5 & 11.vii.19 & B. & 9 & $15-24$ & 1 & 15 & - & - \\
\hline 6 & 18.vii.19 & M.-B. & 2 & $20-21$ & 13 & $16-24$ & - & - \\
\hline 7 & ", & M.-B. & 5 & $18-21$ & 13 & $16-22$ & - & - \\
\hline 8 & , & M.-B. & - & - & 3 & $19-21$ & - & - \\
\hline 9 & ", & M.-B. & - & - & 16 & $9-21.5$ & - & - \\
\hline 10 & 21.vii.19 & B. & - & - & 26 & $11-22$ & - & - \\
\hline 11 & $"$ & B. & - & - & 49 & $11-24$ & - & - \\
\hline 12 & $"$ & B. & - & - & 12 & $11-21$ & - & - \\
\hline 13 & , & B. & - & - & 22 & $13-22$ & - & - \\
\hline 14 & 24.vii.19 & M. & 18 & $15-27$ & 62 & $13-25$ & - & - \\
\hline 15 & ", & S. & 7 & $22-25$ & 71 & $12-23$ & - & - \\
\hline 16 & ", & M. & - & - & - & - & 73 & $13-23$ \\
\hline 17 & 28.vii.19 & M. & - & - & 2 & $15-26$ & - & - \\
\hline 19 & , & M. & - & - & - & - & 2 & $7-8$ \\
\hline 21 & 29.vii.19 & B. & - & - & 3 & $9-14$ & - & - \\
\hline 22 & , & M. & - & - & 21 & $9-12$ & - & - \\
\hline 23 & $"$ & S. & - & - & 11 & $6-11$ & - & - \\
\hline 24 & , & B. & - & - & 26 & $7-18$ & - & - \\
\hline 25 & ", & B. & - & - & 29 & $9-15$ & - & - \\
\hline 26 &, & B. & - & - & 29 & $6-14$ & - & - \\
\hline 27 & 31.vii.19 & S. & 3 & $17-25$ & 2 & 21 & - & - \\
\hline 28 & , & B. & - & - & 7 & $13-20$ & - & - \\
\hline
\end{tabular}


No. of C. sprattus. S. pilchardus. C. $s p$.

Haul. Date. Depth. No. Size in mm. No. Size in mm. No. Size in mm.

\begin{tabular}{|c|c|c|c|c|c|c|c|c|}
\hline 29 & 1.viii.19 & B. & - & - & 1 & 8 & - & - \\
\hline 30 & ", & B. & - & - & 7 & $9-14$ & - & - \\
\hline 31 & ", & B. & - & - & 9 & $11-19$ & - & - \\
\hline 33 & 5.viii.19 & M. & - & - & 1 & 11 & - & - \\
\hline 34 & ", & B. & - & - & 15 & $8-15$ & - & ${ }^{2}-$ \\
\hline 35 & , & B. & - & - & 35 & $9-21$ & - & - \\
\hline 36 & , & S. & - & - & 48 & $13-25$ & - & - \\
\hline 37 & , & B. & 1 & 21 & 15 & $11-21$ & - & - \\
\hline 38 & , & M. & - & - & 37 & $10-23$ & - & - \\
\hline 39 & , & B. & - & - & 123 & $9 \cdot 5-20$ & - & - \\
\hline 41 & 7.viii.19 & M. & - & - & 3 & $10-21$ & - & - \\
\hline 42 & , & B. & 1 & 21 & 3 & $17 \cdot 5-24$ & - & - \\
\hline 43 & , & B. & - & - & 4 & $13 \cdot 5-22$ & - & - \\
\hline 44 & 8.viii.19 & M. - B. & - & - & 14 & $11-19$ & - & - \\
\hline 45 & , & M. & - & - & 12 & $10-20$ & - & - \\
\hline 46 & , & S. & 4 & 19-25 & 21 & $9-25$ & - & - \\
\hline 47 & ", & B. & - & - & 21 & $12-22$ & - & - \\
\hline 48 & 11.viii.19 & B. & - & 一 & 2 & $14-15$ & - & - \\
\hline 52 & 13.viii.19 & M. & 1 & 18 & - & - & - & - \\
\hline 56 & 15.viii.19 & B. & 12 & $18-22$ & 150 & $14-20$ & - & - \\
\hline 57 & 1.ix.19 & B. & - & - & 71 & $12-25$ & - & - \\
\hline 58 & " & B. & - & - & 9 & $12-28$ & - & - \\
\hline 60 & 3.ix.19 & M. & - & - & 17 & $11-23$ & - & - \\
\hline 61 & , & B. & - & - & 65 & $12-23$ & - & - \\
\hline 62 & 9.ix.19 & S. & - & - & 76 & $14 \cdot 5-28 \cdot 5$ & - & - \\
\hline 63 & , & . M. & - & - & 4 & $18-23$ & - & - \\
\hline 64 & , & B. & - & 一 & 8 & $17-27$ & - & - \\
\hline 65 & , & S. & - & - & 76 & $14-24$ & - & - \\
\hline 66 & , & B. & - & - & 37 & $14-23$ & - & - \\
\hline 67 & 10.ix.19 & S. & - & - & 21 & $14-20$ & - & - \\
\hline 68 & , & M. & - & - & 32 & $11-22 \cdot 5$ & - & - \\
\hline 69 & 17.ix.19 & B. & - & - & 3 & $15-27$ & - & - \\
\hline 70 & , & B. & - & - & 9 & $14-23$ & - & - \\
\hline 71 & , & B. & - & - & 1 & 21 & - & - \\
\hline 72 & , & B. & - & - & 2 & $24-26$ & - & - \\
\hline 75 & 19.ix.19 & M. & - & - & 2 & $21-25$ & - & - \\
\hline 76 & 25.ix.19 & B. & - & - & 18 & $10-24 \cdot 5$ & - & - \\
\hline 79 & $"$ & M. -B. & - & - & 5 & $10-19$ & - & - \\
\hline 80 & , & M. - B. & - & - & 15 & $9-28$ & - & - \\
\hline
\end{tabular}




\section{TABLE XII.}

Apparatus C.

Record of SARdina pilchardus.

\begin{tabular}{|c|c|c|c|c|c|c|c|c|}
\hline No. of hauld & & Date. & & Depth. & & No. & & Size in $\mathrm{mm}$. \\
\hline 1 & . & 19.vii.19 & . & S.-M. & . & 10 & . & $17-23$ \\
\hline 2 & . & , & . & S.-M. & . & 31 & . & $19-26$ \\
\hline 3 & . & , & . & M. & . & 7 & . & $22-24$ \\
\hline 4 & . & 25.viii.19 & . & B. & 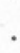 & 88 & . & $19-25$ \\
\hline 8 & . & 8.ix.19 & . & M. & $\cdot$ & 2 & . & 20 \\
\hline 11 & . & 9.ix.19 & ${ }^{\circ}$ & B. & . & 2 & . & $22-27$ \\
\hline 12 & . & ", & . & M. & ${ }^{\circ}$ & 1 & . & 28 \\
\hline 13 & . & " & • & M.-B. & $\cdot$ & 1 & . & 13 \\
\hline 14 & . & , & & S.-M. & & 2 & . & $16-29$ \\
\hline 16 & . & 10.ix.19 & . & S. & . & 3 & . & $15-24$ \\
\hline
\end{tabular}

\section{SOLENICHTHYES.}

\section{SYNGNATHID A. PIPE FISHES.}

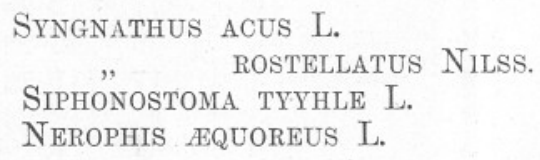

\section{Apparatus A and B.}

Syngnathus rostellatus was the only species which occurred off shore, and only two young stages were captured, one of $21 \mathrm{~mm}$. in Haul 7 on 18th July, 1919, and one of $56 \mathrm{~mm}$. in Haul 69 on 17th September, 1919.

Siphonostoma typhle occurred as a single individual in Haul 77 (Cawsand Bay) at a length of $97 \mathrm{~mm}$. on 25th September, 1919, and Nerophis cquoreus was represented by two young forms, 12 to $22 \mathrm{~mm}$. in length, captured in Haul 80, West Channel, on the same date.

\section{Apparatus C.}

Adolescent and adult stages of Syngnathus acus, S. rostellatus and Siphonostoma typhle were taken with the cotton trawl C in August and September in Whitsand and Cawsand Bays, all in shallow water close inshore. Siphonostoma typhle was found to be carrying the young in the brood pouch in August. The records here given of these three species are not quite representative, as many rich hauls of these fish were transferred alive from the Cawsand Bay Zostera bed to the aquarium tanks 
for special public exhibition. Nerophis lumbriciformis was also present in these hauls, which were made with the cotton net and with the ordinary shrimp trawl.

\section{TABLE XIII.}

Apparatus A AND B.

\section{Record of Syngnathide.}

\begin{tabular}{|c|c|c|c|c|c|c|c|c|}
\hline \multirow{2}{*}{$\begin{array}{c}\text { No. of } \\
\text { Haul. } \\
7\end{array}$} & \multirow{2}{*}{$\begin{array}{l}\text { f Date. } \\
\text { 18.vii.19 }\end{array}$} & \multirow{2}{*}{$\begin{array}{l}\text { Depth. } \\
\text { M.-B. }\end{array}$} & \multicolumn{2}{|c|}{$\begin{array}{c}\text { Syngnathus } \\
\text { rostellatus. } \\
\text { No. Size in mm. }\end{array}$} & \multicolumn{2}{|c|}{$\begin{array}{l}\text { Siphonostoma } \\
\text { typhle. } \\
\text { No. Size in } \mathrm{mm} .\end{array}$} & \multicolumn{2}{|c|}{$\begin{array}{c}\text { Nerophis } \\
\text { aequoreus. } \\
\text { No. Size in mm }\end{array}$} \\
\hline & & & 1 & 21 & - & - & - & - \\
\hline 69 & 17.ix.19 & M. & 1 & 56 & - & - & - & - \\
\hline 77 & 25.ix.19 & B. & - & - & 1 & 97 & - & - \\
\hline 80 & & B. & & - & - & - & 2 & $12-22$ \\
\hline
\end{tabular}

\section{TABLE XIV.}

\section{Apparatus C.}

RECORD of SyNGNATHID无.

\begin{tabular}{|c|c|c|c|c|c|c|c|c|}
\hline $\begin{array}{l}\text { No. of } \\
\text { Haul. }\end{array}$ & Date. & Depth. & $\begin{array}{l}\text { Syng, } \\
\text { No. }\end{array}$ & $\begin{array}{l}\text { ius acus. } \\
\text { e in mm. }\end{array}$ & $\begin{array}{r}S . \\
\text { No. }\end{array}$ & $\begin{array}{l}\text { ostellatus. } \\
\text { Size in mm. }\end{array}$ & No. ${ }^{S}$ & $\begin{array}{l}\text { typhle. } \\
\text { Size in mm. }\end{array}$ \\
\hline 5 & 26.viii.19 & B. & - & - & - & - & 1 & 220 \\
\hline 22 & 16.ix.19 & B. & 8 & $95-145$ & - & - & - & - \\
\hline 23 & & B. & 2 & $98-105$ & - & 一 & - & - \\
\hline 24 & 18.ix.19 & B. & - & - & 4 & $95-105$ & - & - \\
\hline 25 & , & B. & - & - & 13 & $77-140$ & - & 一 \\
\hline 26 & 23.ix.19 & B. & - & - & - & - & 7 & $185-2$ \\
\hline 27 & , & B. & - & - & 2 & $100-105$ & 1 & 175 \\
\hline
\end{tabular}

\section{APODES.}

CONGRIDAE.

\section{LEPTOCEPHALUS CONGRI VULGARIS (L. Morrisii).}

Apparatus B.

A single Leptocephalus stage of the Conger occurred in Haul 69 (Bottom) on 17th September, 1919. It measured approximately $115 \mathrm{~mm}$. when brought in alive to the Laboratory. Fortunately the young fish has survived and enabled observations to be made on its rate of growth. The reduction in length during metamorphosis is a distinctive feature.

The specimen has been carefully looked after by Mr. Ford, who gives in the same volume of this Journal a few notes on his observations along with a table of the captures of Leptocephali of the Conger round our coasts. 


\title{
ANACANTHINI.
}

\author{
GADID AE.
}

\section{Gadus POLLachius L. Pollack.}

In the 1919 hauls, July to September (inclusive) pelagic young of the Pollack had disappeared, with the exception of one post-larva of $5 \mathrm{~mm}$. secured on 21st July, 1919. This result is not surprising as the Pollack is a spring spawner in this area, and may well have reached the bottom stage by July. Adolescent stages have been taken in Cawsand Bay at lengths from 3 to $5 \mathrm{~cm}$. in June. They are extreemly abundant in the Zostera bed of Cawsand Bay, and are invariably present in every haul of the shrimp trawl in summer and autumn. Two hauls (Nos. 4 and 5, Apparatus C) gave 53 fish from 60 to $120 \mathrm{~mm}$. in length for a total duration of 64 minutes.

Spawning Period: i-vi.

\section{GADID $\nexists$ E.}

\section{Gadus merlangus L. Whiting.}

This was the most frequent Gadoid. in the pelagic young stage during the period of the 1919 investigations. Sixty-nine post-larvæ, 5-17 mm., were captured in July and 11 varying from $5 \mathrm{~mm}$. upwards in August, all in the area between Rame Head and the Eddystone. The average per haul (23.5 minutes) for July is $2 \cdot 3$. Dr. Allen gives the maximum number per haul (ca. 20 minutes) for the years 1906-1914 as 33.6 for May month. This is a fairly high percentage, especially for a fish of commercial importance, and shows a large production of the young fry in this area.

The adolescent period is passed in shallow water close to the shore, and a few examples $65-85 \mathrm{~mm}$. were caught in Cawsand and Whitsand Bays with the cotton trawl C in September. These are the young spawned in the earlier part of the year and are at least six months old.

Spawning Period : ii-vii.

\section{GADID $A$.}

Gadus Luscus L. Bib (auctorum). Pout-Plymouth.

The pelagic young stages of this species were extremely limited in number, as only 7 post-larvæ from $8-15 \mathrm{~mm}$. in length were taken during 
the autumn of 1919. The records from 1906-14 gave only 74 post-larvæ44 of which were captured in May-so far the maximum month-with an average of only 1.5 per haul of 20 minutes' duration. These records are supplemented for the earlier months of the year by a few captures in Plymouth Sound recorded by Lebour (1917-1918). The writer is inclined to the idea, however, that a more systematic investigation during the earlier months of the year will supply a better indication of the real state of things with regard to the frequency of the early young of this species. The adult is extremely plentiful in the fishing areas both inside and outside the Eddystone, and forms with Gadus pollachius (Pollack), G. merlangus (Whiting) and G. minutus (Poor-Cod) the chief representatives of the Gadoids in the Plymouth area.

The captures of the early bottom stages by the cotton trawl C are not quite representative of the state of things. They are limited to 6 fish from 33 to $43 \mathrm{~mm}$. captured in one haul in the deeper water off Whitsand Bay, though a few have been taken with the shrimp trawl in the Zostera bed of Cawsand Bay at corresponding sizes also in September.

Spawning Period : xi-vi.

Gadus minutus. Poor Cod (auctorum). Bib-Plymouth.

Pelagic young of this species were absent from the hauls made in July, August and September, 1919. Dr. Allen gives the maximum average number of post-larvæ per haul of 20 minutes as 13.5 in May.

The early bottom stages, however, were well represented in the 1919 material, and their distribution was quite general over the whole areaextending from close inshore out to midchannel, where captures were registered from a depth of 44 fathoms. Table XV records the capture of 196 specimens, 40-160 mm., secured in 5 hauls in July and August with the mosquito net $\mathrm{B}$, while the cotton net $\mathrm{C}$ captured 1111, varying from 58 to $175 \mathrm{~mm}$., during the same period, an average number for the latter of $35 \cdot 8$ specimens per haul of an average duration of $28 \cdot 3$ minutes. One half-hour haul in locality $1 \frac{1}{2}$ miles S. by W. from Rame Head gave 938 bottom stages from $65-90 \mathrm{~mm}$. in length.

Mature adults of this species vary from 150 to $230 \mathrm{~mm}$., but seldom very much larger, so that the present records contain many fish which are undoubtedly over one year old.

Spawning Period: ii-vi. 


\section{TABLE XV.}

Apparatus A and B.

Record of Gadus sp.

\begin{tabular}{|c|c|c|c|c|c|c|c|c|c|c|}
\hline $\begin{array}{l}\text { No. of } \\
\text { Haul. }\end{array}$ & Date. & Depth. & $\begin{array}{c}G . \\
\text { No. }\end{array}$ & $\begin{array}{l}\text { Dllachius. } \\
\text { ize in mm. }\end{array}$ & $\begin{array}{l}G . \\
\text { No. }\end{array}$ & $\begin{array}{l}\text { neriangus. } \\
\text { Size in mm. }\end{array}$ & No. & $\begin{array}{l}\text { luscus. } \\
\text { Size in mm. }\end{array}$ & No. ${ }^{6}$ & $\begin{array}{l}\text { minutus. } \\
\text { Size in mm. }\end{array}$ \\
\hline 1 & 3.vii.19 & B. & - & - & 3 & $6-9$ & - & - & - & - \\
\hline 2 & 7.vii.19 & B. & - & - & 2 & $12-17$ & - & - & - & - \\
\hline 4 & 10.vii.19 & B. & - & - & 14 & $6-17$ & & - & - & - \\
\hline 6 & 18.vii.19 & MI.-B. & - & - & 4 & $8-12 \cdot 5$ & - & - & - & - \\
\hline 7 & , & M.-B. & - & - & 2 & 11 & 一 & - & - & - \\
\hline 8 & ," & M.-B. & - & - & 3 & $6 \cdot 5-9$ & - & - & - & - \\
\hline 9 & ", & M.-B. & - & - & 7 & $7-11$ & - & - & - & - \\
\hline 11 & 21.vii.19 & B. & - & - & 9 & $6-11$ & 1 & 8 & - & - \\
\hline 12 & , & B. & 1 & 5 & 11 & $5-10 \cdot 5$ & - & - & - & - \\
\hline 13 & ", & B. & - & - & 7 & $7-13$ & - & - & - & - \\
\hline 19 & 28.vii.19 & M. & - & - & 1 & 13 & - & - & - & - \\
\hline 20 & 29.vii.19 & B. & - & - & 1 & 11 & - & - & - & - \\
\hline 28 & 31.vii.19 & B. & - & - & 5 & $6-9$ & - & - & - & - \\
\hline 29 & 1.viii.19 & B. & - & - & 1 & 12 & - & - & - & - \\
\hline 32 & , & S. & - & - & 4 & $20-40$ & - & - & - & - \\
\hline 33 & 5.viii.19 & M. & - & - & 1 & 8 & - & - & - & - \\
\hline 34 & , & B. & - & - & 1 & 7 & - & - & - & - \\
\hline 35 & :" & B. & - & - & 4 & $5-7 \cdot 5$ & - & - & - & - \\
\hline 56 & 15.viii.19 & B. & - & - & - & 一. & - & - & 1 & 40 \\
\hline 64 & 9.ix.19 & B. & - & - & - & - & - & - & 9 & $51-89$ \\
\hline 72 & 17.ix.19 & B. & - & - & - & - & - & - & 100 & $64-160$ \\
\hline 73 & & B. & - & - & - & - & 2 & 14 & 79 & $69-110$ \\
\hline 81 & 29.ix.19 & B. & - & - & - & - & 4 & $11-15$ & 7 & $82-143$ \\
\hline
\end{tabular}


TABLE XVI.

Apparatus C.

RECORD OF Gadus sp.

\begin{tabular}{|c|c|c|c|c|c|c|c|c|c|c|}
\hline No. of & Date, & Depth & & pollachius. & & verlangus. & & luscus. & & minutus. \\
\hline & Date. & Depth. & No. & & No. & & No. & Size in $\mathrm{mm}$. & No. & \\
\hline 4 & 25.viii.19 & B. & 12 & $60-120$ & - & - & - & - & 24 & $58-90$ \\
\hline 5 & 26.viii.19 & B. & 41 & $76-109$ & - & - & - & - & 30 & 73-104 \\
\hline 11 & 9.ix.19 & B. & - & - & - & - & - & - & 1 & 60 \\
\hline 15 & ," & M.-B. & - & - & - & - & - & - & 2 & $70-78$ \\
\hline 17 & 12.ix.19 & M. & - & - & - & - & - & - & 92 & $68-175$ \\
\hline 18 & , & B. & - & - & - & - & - & - & 938 & $65-90$ \\
\hline 20 & 16.ix.19 & M. & - & - & 1 & 65 & - & - & - & - \\
\hline 21 & ", & B. & - & - & 1 & 70 & - & - & - & - \\
\hline 24 & 18.ix.19 & B. & - & - & 1 & 82 & - & - & - & - \\
\hline 26 & 23.ix.19 & B. & - & - & - & - & - & - & - & - \\
\hline 27 & ", & B. & - & - & 2 & $67-85$ & - & - & - & - \\
\hline 29 & 29.ix.19 & B. & - & - & - & - & - & - & - & - \\
\hline 30 & , & B. & - & - & 3 & $78-80$ & 6 & $33-43$ & - & - \\
\hline
\end{tabular}




\section{GADID $A$.}

\section{- Molva molva L. Common Ling.}

Ten post-larvæ of the Common Ling, 6-17 mm. in length, occurred. in three hauls on the Rame Eddystone Grounds in July. For 1914, Dr. Allen records a similar number, $8-20 \mathrm{~mm}$. in length, from May to July, while the investigations during the years 1906-1913 yielded only 30 young stages, so that it may be safely considered that the production of the young fry in the area investigated is very small. Schmidt (1906, 1909) has already remarked on the scarcity of the young pelagic stages in the English Channel, their absence in the shallower water of the east, and their presence in small quantity in the deeper water of the west. Adult Ling have only occasionally been taken in the deeper water off Plymouth, but they increase in number westward. No ripe females have been examined.

Spawning Period : iv-vi.

\section{TABLE XVII.}

Apparatus A.

Record of Molva molva.

$\begin{array}{rrrrc}\begin{array}{c}\text { No. of } \\ \text { Haul. }\end{array} & \text { Date. } & \text { Depth. } & \text { No. } & \text { Size in mm. } \\ 4 & \text { 10.vii.19 } & \text { B. } & 4 & 6-15 \\ 8 & \text { 18.vii.19 } & \text { M.-B. } & 1 & 11.5 \\ 12 & \text { 21.vii.19 } & \text { B. } & 5 & 10-17\end{array}$

\section{GADID $A E$.}

\section{Merluccius merluccius L. Hake.}

Thirteen young Hake from 4.5 to $13 \mathrm{~mm}$. occurred in 8 hauls from the end of July to middle of September, 1919. These are apparently the first observations on the young of this species in Plymouth waters. Ten of these were captured in deeper water of about 40 fathoms in midchannel, 15 miles W.S.W. of the Eddystone Rocks, but three appeared in hauls between Rame Head and Eddystone over depths ranging from 20 to 30 fathoms. They agree very well with Schmidt's excellent figures and descriptions (1907 a). The distribution of this species in the area investigated is similar to that for the Common Ling. Both show a tendency to occur in deeper water, though the records are rather few to draw conclu- 
sions. Schmidt (1909) records a few small individuals which were captured in the western part of the English Channel in May and June.

Spawning Period: vi.-viii.

One ripe female was observed by the writer in July, 1913. This was secured in the Oithona's Otter Trawl, in the fishing grounds outside the Eddystone.

\section{TABLE XVIII.}

Apparatus A and B.

Record of Merluccius merluccius.

$\begin{array}{ccccc}\text { No. of } & \text { Date } & \text { Depth. } & \text { No. } & \text { Size in mm. } \\ \text { Haul. } & \text { 31.vii. } 19 & \text { B. } & 1 & 5 \cdot 5 \\ 28 & \text { 8.viii.19 } & \text { M.-B. } & 1 & 5 \\ 44 & \text { " } & \text { B. } & 1 & 4 \cdot 5 \\ 47 & 9 . i x .19 & \text { S. } & 1 & 13 \\ 62 & \text { " } & \text { M. } & 1 & 9 \cdot 5 \\ 63 & \text { " } & \text { B. } & 4 & 9-10 \\ 64 & \text { B. } & 3 & 7-11 \\ 66 & 17 . \ddot{i x .19} & \text { B. } & 1 & 10 \\ 69 & & \text {. } & \end{array}$

\section{GADIDAE.}

Raniceps Raninus L. Lesser Forkbeard.

Apparatus B.

A single post-larva, $12 \mathrm{~mm}$. in length, was taken in a surface night haul (No. 67) on 10th September, 1919, in latitude $49^{\circ} 58^{\prime} .5$ N., longitude $4^{\circ} 25^{\prime} \cdot 2 \mathrm{~W}$. over a depth of 41 fathoms. It is well represented by Schmidt's figure of a specimen, $12 \frac{1}{4} \mathrm{~mm}$. (1907 b). For 1914, Dr. Allen records a post-larva $8 \mathrm{~mm}$. in length at the end of July, while the writer recorded eight specimens $(4 \cdot 5-18.5 \mathrm{~mm}$.) in August and September, 1913. The distribution of the post-larvæ here recorded is identical with that for the Ling and the Hake. They were all secured over total depths greater than 20 fathoms, in localities west of Rame Head, round the Eddystone Rocks and in midchannel. Their numbers are exceedingly few and give indications that the area in question is poorly represented by this species.

The writer, so far, has not observed any adults in this area, though they are known to have been captured farther west off the Cornish coast, through observations by Mr. Matthias Dunn, Newlyn, who has sent specimens to the Laboratory for identification.

Spawning Period: vi-viii. 


\section{GADID丑.}

$\begin{array}{cl}\text { Onos mustelus L. } & \text { Five-bearded Rockling. } \\ \text {, TRICIRRAtus Bloch. } & \text { Three " } \\ " \text { CIMbrius L. } & \text { Four ", }\end{array}$

The identification of the early young Rocklings still remains doubtful. Most of those recorded in Table VII belong to the five-bearded species, O. mustelus, 23 specimens, $4-8 \mathrm{~mm}$., having been secured in July, and beginning of August. These occurred in:13 hauls taken inside and outside the Eddystone.

On 29th September, 1919, Bottom Haul No. 31 of the cotton trawl C yielded a single adult Onos cimbrius $160 \mathrm{~mm}$. in length. This species has only been taken occasionally in the adult stage near Plymouth and the spawning period for this area has not been recorded. The writer, however, secured a ripe female, $150 \mathrm{~mm}$. in length, in a "Mosquito " townet attached to the Otter Trawl on 2nd September, 1913, in locality $3 \frac{1}{2}$ miles W.S.W. from Rame Head at a depth of 26 fathoms. The eggs measured (after the specimen had been in formalin) .8 to $.875 \mathrm{~mm}$. In this $150 \mathrm{~mm}$. specimen, the first ray of the anterior dorsal measured 33 $\mathrm{mm}$. and the head $26 \mathrm{~mm}$.

$\begin{array}{cccc} & \text { O. mustelus. } & \text { Otri-cirratus. } & \text { O. cimbrius. } \\ \text { Spawning Period : } & \text { i-vii. } & \text { v-viii. } & \text { ix. }\end{array}$

\section{TABLE XIX.}

Apparatus A AND B.

RECORD OF ONOS sp.

\begin{tabular}{|c|c|c|c|c|c|c|c|c|}
\hline $\begin{array}{l}\text { No. of } \\
\text { Haul. }\end{array}$ & Date. & Depth. & $\begin{array}{r}0 . \\
\text { No. }\end{array}$ & $\begin{array}{l}\text { mustelus. } \\
\text { Size in } \mathrm{mm} .\end{array}$ & $\begin{array}{l}\text { o. } \operatorname{tri} \\
\text { No. Si }\end{array}$ & $\begin{array}{l}\text { cirratus. } \\
\text { e in mm. }\end{array}$ & No. & $\begin{array}{l}\text { O. sp. } \\
\text { Size in mm }\end{array}$ \\
\hline 2 & 7.vii.19 & B. & 2 & $6-8$ & - & - & - & - \\
\hline 3 & 9.vii.19 & M. & 1 & 8 & - & - & - & - \\
\hline 4 & 10.vii.19 & B. & 1 & 5 & - & - & - & - \\
\hline 9 & 18.vii.19 & M.-B. & 2 & $6-8$ & - & - & - & - \\
\hline 11 & 21.vii.19 & B. & 2 & $5-6$ & 1 & 31 & - & - \\
\hline 12 &, & B. & 4 & $5-7$ & - & - & - & - \\
\hline 13 & , & B. & 1 & 6.5 & - & - & - & - \\
\hline 14 & 24.vii.19 & M. & 1 & 8 & - & - & - & - \\
\hline 24 & 29.vii.19 & B. & 4 & $6-7$ & 一 & - & - & - \\
\hline 25 & , & B. & 2 & $4-5$ & 2 & $23-25$ & - & - \\
\hline 26 & $"$ & B. & - & - & - & - & 1 & 10 \\
\hline 27 & 31.vii.19 & S. & - & - & - & - & 1 & 9 \\
\hline 28 & , & B. & 1 & 6 & - & - & - & - \\
\hline 31 & 1.viii.19 & B. & 1 & 5 & - & - & - & - \\
\hline 39 & 5.viii.19 & B. & 1 & 7 & - & - & - & - \\
\hline
\end{tabular}




\section{ZEOMORPHI.}

\section{CAPROID $A$.}

\section{CAPROS APER L. Boarfish.}

Three post-larvæ. 6-7 mm. in length, were secured in September, 1919. These were in two surface night hauls-one $6.3 \mathrm{~mm}$. in Haul 62 on 9th September and two 6-7 mm. in Haul 67 on 10th September, 1919, both over depths of 41 fathoms. Eleven young stages $-3 \cdot 3$ to $6 \mathrm{~mm}$. were recorded during August and September, 1913, and these were also secured in deeper water chiefly round the Eddystone Rocks. All the Plymouth records so far are confined to hauls in water of over 20 fathoms in total depth, while the post-larvæ have occurred in surface, midwater and bottom hauls.

In Plymouth waters, spawning extends-according to Cunningham, Holt and Hefford - from June to August, with a maximum in July, and may take place not far from the shore, as Holt has already remarked. The writer has trawled numerous ripe adults of this species on the inshore fishing grounds between the Eddystone and Rame Head in July and August.

Spawning Period: vi-viii.

TABLE XX.

Apparatus B.

RECORD OF CAPROS APER.

$\begin{array}{ccccc}\begin{array}{c}\text { No. of } \\ \text { haul. }\end{array} & \text { Date. } & \text { Depth. } & \text { No. } & \text { Size in } \mathrm{mm} . \\ 62 & 9 . i x .19 & \text { S. } & 1 & 6 \cdot 3 \\ 67 & \text { 10.ix.19 } & \text { S. } & 2 & 6-7\end{array}$

HETEROSOMATA.

PLEURONECTIFORMES.

BOTHID死.

Sub-Fam. Platophrinæ.

Arnoglossus laterna (Will) Scaldback.

The scales in the adult are very deciduous, hence the popular name of Scaldback. The pelagic young occur in 53 hauls out of 84 , with an average of $5 \cdot 7$ specimens per haul. The maximum number is in September, 
when the average per haul is 11.6 specimens. They are distributed generally over the whole area, fewer inshore than in the deeper water offishore, and are extremely common on the Rame-Eddystone grounds. Post-larvæ have not been recorded earlier than May nor later than beginning of October, so that the spawning period, judged from the lengths of the very early stages, probably lies between the end of April and middle of September for this neighbourhood. The eggs of $A$. laterna and grohmanni have been observed in June and July.

The smallest completely metamorphosed A. laterna was $24 \mathrm{~mm}$., though there is a good deal of variation in the length. Specimens $24.5 \mathrm{~mm}$. and $25 \cdot 6$ had only just begun, while post-larvæ at $19 \cdot 5$ and $22 \mathrm{~mm}$. were at least half-way through their metamorphosis, the right eye being almost on the top of the ridge at the smaller of these two lengths and just over the top at the larger length, while the dorsal fin in the latter had not yet reached the snout, the usual gap still being present, where the right eye had travelled round the head. The reduction in length at metamorphosis is very noticeable.

The hauls of the cotton trawl C record the capture of adolescent stages of $A$. laterna from $28 \mathrm{~mm}$. upwards in the shallow water of the bays and in deeper water between Rame Head and Eddystone.

Spawning Period : vi-viii.

\section{TABLE XXI.}

Apparatus A and B.

Record of ARnoglossus sp.

$\begin{array}{ccccccc}\begin{array}{c}\text { No. of } \\ \text { haul. }\end{array} & \text { Date. } & \text { Depth. } & \text { No. } \begin{array}{c}\text { A. laterna. } \\ \text { Size in mm. }\end{array} & \text { No. } & \begin{array}{c}\text { A. sp. } \\ \text { Size in mm. }\end{array} \\ 1 & \text { 3.vii.19 } & \text { B. } & 2 & 9-11 \cdot 5 & - & - \\ 4 & \text { 10.vii.19 } & \text { B. } & - & - & 2 & 5-7 \cdot 5 \\ 7 & \text { 18.vii.19 } & \text { M.-B. } & 3 & 4-11 & - & - \\ 8 & \text { ", } & \text { M.-B. } & - & - & 1 & 4 \\ 9 & \text { ". } & \text { M.-B. } & 5 & 4-10 & - & - \\ 10 & 21 . \text { vii.19 } & \text { B. } & 5 & 4-18 & - & - \\ 11 & \text { ", } & \text { B. } & 8 & 6-135 & - & - \\ 12 & \text { ", } & \text { B. } & 4 & 7-19 & - & - \\ 13 & \text { ", } & \text { B. } & 4 & 8-15 & - & - \\ 14 & 24 . v i i .19 & \text { M. } & - & - & 1 & 7 \cdot 5 \\ 18 & 28 . v i i .19 & \text { M.-B. } & - & - & 1 & 10 \\ 19 & \text { ", } & \text { M. } & - & - & 1 & 4\end{array}$




\begin{tabular}{|c|c|c|c|c|c|c|}
\hline $\begin{array}{l}\text { No. of } \\
\text { haul. }\end{array}$ & Date. & Depth. & No. & $\begin{array}{l}\text { laterna. } \\
\text { Size in mm. }\end{array}$ & No. & $\begin{array}{l}\text { A. sp. } \\
\text { Size in } \mathrm{mm}\end{array}$ \\
\hline 20 & 29.vii.19 & B. & 4 & $6-19$ & - & - \\
\hline 21 & , & B. & 5 & 5 & - & - \\
\hline 22 & , & M. & 24 & $4 \cdot 5-11$ & - & - \\
\hline 23 & , & S. & 6 & 4-9 & - & - \\
\hline 24 & , & B. & 3 & $7-10 \cdot 5$ & - & - \\
\hline 25 & , & B. & 4 & $7-11$ & - & - \\
\hline 26 & $\cdots$ & B. & - & - & 3 & 、 $9-11$ \\
\hline 28 & 31.vii.19 & B. & 7 & $11-24$ & - & - \\
\hline 30 & 1.viii.19 & B. & 2 & $4 \cdot 5-6$ & - & - \\
\hline 31 & , & B. & 6 & $8-21$ & - & - \\
\hline 32 & , & S. & 1 & 6 & - & - \\
\hline 33 & 5.viii.19 & M. & 2 & $-5-5 \cdot 5$ & - & - \\
\hline 34 &, & B. & 5 . & $5-13$ & - & - \\
\hline 35 & ", & B. & 4 & $5-16$ & - & - \\
\hline 36 & , & S. & 1 & 9.5 & - & - \\
\hline 37 & , & B. - & 10 & $9-16$ & - & - \\
\hline 38 & , & M. & 7 & $5-9$ & - & - \\
\hline 39 & , & B. & 9 & $5-9$ & - & - \\
\hline 41 & 7.viii.19 & M. & 1 & 8 & - & - \\
\hline 42 & , & B. & 3 & $7-14 \cdot 5$ & - & - \\
\hline 43 &, & B. & 6 & $7-17$ & - & - \\
\hline 44 & 8.viii.19 & M.-B. & 9 & $5-11$ & 一 & - \\
\hline 45 & 8.viii.19 & M. & 5 & $11-19$ & - & - \\
\hline 47 & , & B. & 7 & $6 \cdot 5-12$ & - & - \\
\hline 48 & 11.viii.19 & B. & 5 & $5-16$ & - & - \\
\hline 54 & 13.viii.19 & M. & 1 & 10 & - & - \\
\hline 55 & 14.viii.19 & B. & 2 & $10-15$ & - & - \\
\hline 56 & 15.viii.19 & B. & 13 & $11-18$ & - & - \\
\hline 57 & 1.ix.19 & B. & 3 & $7-15$ & - & - \\
\hline 62 & 9.ix.19 & S. & - & - & 55 & $6-21 \cdot 5$ \\
\hline 63 & , & M. & - & - & 4 & $8-17$ \\
\hline 65 & " & S. & - & - & 24 & $7-21$ \\
\hline 66 & , & B. & - & - & 23 & $8-22$ \\
\hline 67 & 10.ix.19 & S. & - & - & 100 & $6-20$ \\
\hline 68 & ," & M. & 1 & 24 & 22 & $7-24$ \\
\hline 69 & 17.ix.19 & B. & - & - & 10 & $10-19$ \\
\hline 70 & , & B. & - & - & 4 & $9-20$ \\
\hline 74 & 19.ix.19 & B. & - & - & 1 & $12 \cdot 5$ \\
\hline 76 & 25.ix.19 & B. & - & - & 6 & $8-12$ \\
\hline 79 & , & B. & - & - & 21 & $9-17$ \\
\hline 80 & , & M.-B. & - & - & 16 & $9-14.5$ \\
\hline
\end{tabular}

NEW SERIES.-VOL. XII. NO. 2. JULY, 1920. 


\section{TABLE XXII.}

Apparatus C.

\section{ReCord of Arnoglossus sp.}

\begin{tabular}{|c|c|c|c|c|c|c|}
\hline $\begin{array}{l}\text { No. of } \\
\text { haul. }\end{array}$ & Date. & Depth. & No. & $\begin{array}{l}\text { laterna. } \\
\text { Size in } \mathrm{mm} .\end{array}$ & No. & $\begin{array}{l}\text { A. sp. } \\
\text { Size in } \mathrm{mm} \text {. }\end{array}$ \\
\hline 4 & 25.viii.19 & B. & 2 & $13-15$ & - & - \\
\hline 6 & 3.ix.19 & B. & 4 & $7-15$ & - & - \\
\hline 7 & 8.ix.19 & S. & 3 & $17-23$ & - & - \\
\hline 8 & ", & M. & 6 & $17-24$ & - & - \\
\hline 10 & , & S. & - & - & 5 & $11-23$ \\
\hline 11 & 9.ix.19 & B. & - & - & 2 & $24-27$ \\
\hline 12 & , & M. & - & - & 2 & $25-29$ \\
\hline 14 & ", & S.-M. & - & - & 1 & 26 \\
\hline 15 & , & M.-B. & - & - & 2 & $19-24$ \\
\hline 17 & 12.ix.19 & B. & 5 & $95-115$ & - & - \\
\hline 18 & ", & B. & 14 & $90-130$ & - & - \\
\hline 21 & 16.ix.19 & B. & 3 & $42-105$ & - & - \\
\hline 22 & ", & B. & 4 & $49-111$ & - & - \\
\hline 23 & , & B. & 1 & 44 & - & - \\
\hline 24 & 18.ix.19 & B. & - & - & 5 & $46-118$ \\
\hline 28 & 25.ix.19 & B. & 1 & 35 & $\div$ & - \\
\hline 30 & , & B. & 16 & 28-132 & - & - \\
\hline 31 & , & B. & 2 & $92-100$ & - & - \\
\hline
\end{tabular}

Sub-Fam. BOTHINA.

Rhombus maximus L. Turbot. „ Lavis Rond. Brill.

Few post-larvæ of either species were taken in the hauls of the youngfish trawls, and they disappeared from the captures in the beginning of August. The investigations for the years 1906-1914 and 1919 show that the spawning of the Turbot during July and August and the Brill in July is very small indeed, as the records of the young fish trawl for all the years are extremely few. That the maximum spawning period for each species occurs earlier in the year, and that both species are well represented in the Plymouth area are proved by the abundance of the later pelagic young and early bottom stages.

Young metamorphosing stages of the Brill, still at the surface, occur regularly in large numbers in May and June in the areas close inshore. Garstang (1895) remarks, "Every year at this time (May month) the 
harbour is invaded by shoals of young Brill (Rhombus lavis) in their pelagic stage." Numerous early bottom stages of the Turbot $25-50 \mathrm{~mm}$. in length have been taken with hand nets, worked from the shore in Whitsand Bay in August and September.

The working of a shore seine would add greatly to our knowledge of the numbers of these two important species in the Plymouth area.

\section{R. maximus. $\quad$ R. lacvis.}
Spawning Period:
(?) vi-viii.
(?) iv-viii.

\section{TABLE XXIII.}

Apparatus A and B.

\section{Record of Rhombus sp.}

\begin{tabular}{|c|c|c|c|c|c|c|}
\hline No. of & & & & naximus. & & R. lacvis. \\
\hline haul. & $\begin{array}{c}\text { Date. } \\
\text { 24 vii.19 }\end{array}$ & $\begin{array}{c}\text { Depth. } \\
\text { B. }\end{array}$ & No. & Size in $\mathrm{mm}$. & $\begin{array}{c}\text { No. } \\
9\end{array}$ & $\begin{array}{c}\text { Size in } \mathrm{mm} \text {. } \\
4-6.5\end{array}$ \\
\hline 17 & 28.vii.19 & M. & - & - & 1 & 4 \\
\hline 27 & 31.vii.19 & S. & 1 & 7 & - & - \\
\hline 37 & 5.viii.19 & B. & 1 & 6 & - & - \\
\hline 44 & 8.viii.19 & M. - B. & 一 & - & 1 & $6 \cdot 5$ \\
\hline
\end{tabular}

Scophthalmus norvegicus Gunther.-Norway Topknot.

\section{$\begin{array}{cl}\text { Zeugopterus } & \text { Unimaculatus Bnp. } \\ \text { PUNatus (Bloch). }\end{array}$}

Post-larvæ of Lepidorhombus megastoma (Don.), the Megrim have not been observed in the hauls of the young fish trawl, though the adult is of common occurrence in the deeper water off Plymouth.

The commonest post-larva belongs to the Norway Topknot, Scophthalmus norvegicus, 271 specimens from 4.5 to $11 \mathrm{~mm}$. having been secured. The maximum number was taken in July with an average of 8.6 per haul for this month. Dr. Allen gives an average of $14 \cdot 6$ per haul for the previous years in May month, which approximates more to the middle of the spawning period, which extends from March to June. Metamorphosis is nearing completion in specimens of $11 \mathrm{~mm}$. of $S$. norvegicus and thus at a smaller size than Petersen (1909) records for his specimens. The dorsal fin has extended on to the snout and the migrating eye is completely closed in. The pectorals have become more elongated and permanent rays have developed.

Only two post-larvæ of Zeug. punctatus were recorded in July, and these were in process of metamorphosis. The eggs of this species have been observed from February to May, sor that their comparative absence from the pelagic hauls is easily explained. 
Post-larvæ of the Norway Topknot (S. norvegicus) are distributed over the whole of the area investigated. One adolescent stage of $26 \mathrm{~mm}$. was secured in Haul 15 of the cotton trawl C on 9th September, 1919, at a depth of 42 fathoms.

$\begin{array}{cccc} & \text { S. norvegicus. } & \text { S. unimaculatus. } & \text { Z. punctatus. } \\ \text { Spawning Period : } & \text { iii-vi. } & \text { iv-vi. } & \text { ii.-v. }\end{array}$

\section{TABLE XXIV.}

Apparatus A and B.

\section{Record of Scophthalmus and Zeugopterus.}

\begin{tabular}{|c|c|c|c|c|c|c|c|c|}
\hline $\begin{array}{l}\text { No. of } \\
\text { Haul. }\end{array}$ & Date. & Depth. & $\begin{array}{l}S . \\
\text { No. }\end{array}$ & $\begin{array}{l}\text { orvegicus. } \\
\text { Size in } \mathrm{mm} \text {. }\end{array}$ & $\begin{array}{l}\text { S. un } \\
\text { No. }\end{array}$ & $\begin{array}{l}\text { imaculatus. } \\
\text { Size in mm. }\end{array}$ & $\begin{array}{l}Z . \\
\text { No. }\end{array}$ & $\begin{array}{l}\text { inctatus. } \\
\text { ize in mr }\end{array}$ \\
\hline 3 & 9.vii.19 & M. & 2 & 9 & - & - & - & - \\
\hline 4 & 10.vii.19 & B. & 20 & $5 \cdot 5-9$ & - & - & - & - \\
\hline 5 & 11.vii.19 & B. & - & - & 2 & 7 & - & - \\
\hline 6 & 18.vii.19 & M.-B. & 3 & $7-9$ & - & - & - & - \\
\hline 7 & ", & M.-B. & 1 & $5 \cdot 5$ & - & - & - & - \\
\hline 9 & , & M.-B. & 11 & $5 \cdot 5-8$ & - & - & - & - \\
\hline 10 & 21.vii.19 & B. & 32 & $5-10$ & - & - & 1 & 8 \\
\hline 11 & , & B. & 52 & $5-10$ & - & - & 1 & $10 \cdot 5$ \\
\hline 12 & ", & B. & 69 & $6-10$ & - & - & - & - \\
\hline 13 & , & B. & 53 & $4 \cdot 5-11$ & - & - & - & - \\
\hline 18 & 28.vii.19 & M.-B. & 1 & 7 & - & 一 & - & - \\
\hline 23 & 29.vii.19 & S. & 1 & 5 & - & - & - & - \\
\hline 24 & , & B. & 3 & $6-9$ & - & - & - & - \\
\hline 25 & " & B. & 6 & $5-7$ & - & - & - & - \\
\hline 26 & , & B. & 4 & $5 \cdot 5-8$ & - & - & - & - \\
\hline 28 & 31.vii.19 & S. & 1 & $6 \cdot 5$ & - & - & - & - \\
\hline 31 & 1.viii.19 & B. & 9 & $6-9$ & - & - & - & - \\
\hline 34 & 5.viii.19 & B. & 1 & 5 & - & - & - & - \\
\hline 47 & 8.viii.19 & B. & 1 & 8.5 & - & - & - & - \\
\hline 63 & 9.ix.19 & M. & 1 & 11 & - & - & - & - \\
\hline
\end{tabular}

\section{PLEURONECTID里.}

Pleuronectes platessa L. Plaice. IIMANDA L. COMmon DaB. microcephalus Don. Lemon Dab. FLESUS L. FLOUNDER.

$\begin{array}{ccccc} & \text { P. platessa. } & \text { P. limanda. } & \text { F. microcephalus. } & \text { P. flesus. } \\ \text { Spawning Period : } & \text { xui-v. } & \text { ii-vi. } & \text { ii-vii. } & \text { ii-iv. }\end{array}$ 


\section{P. limanda. Common DaB.}

Only two post-larvæ, 12.5 and $13 \mathrm{~mm}$., were taken in the beginning of July, after which time they disappeared from the pelagic hauls. The maximum month for post-larvæ falls in May.

The captures with the cotton trawl $\mathrm{C}$ were taken mostly in shallow water close inshore. The small number of hauls must be considered in the estimation of the number of fish captured.

\section{P. microcephalus. Lemon DAB.}

The pelagic young of this species persist in the hauls later than any of the other species of Pleuronectes. This is due not to a later spawning period but to a longer pelagic life. The species is a deeper water form and the main spawning probably takes place well offshore.

No early bottom stages were secured in the area under investigation.

The largest post-larva observed at Plymouth was taken in Haul 48 on 2nd July, 1914, and measured $18.5 \mathrm{~mm}$.

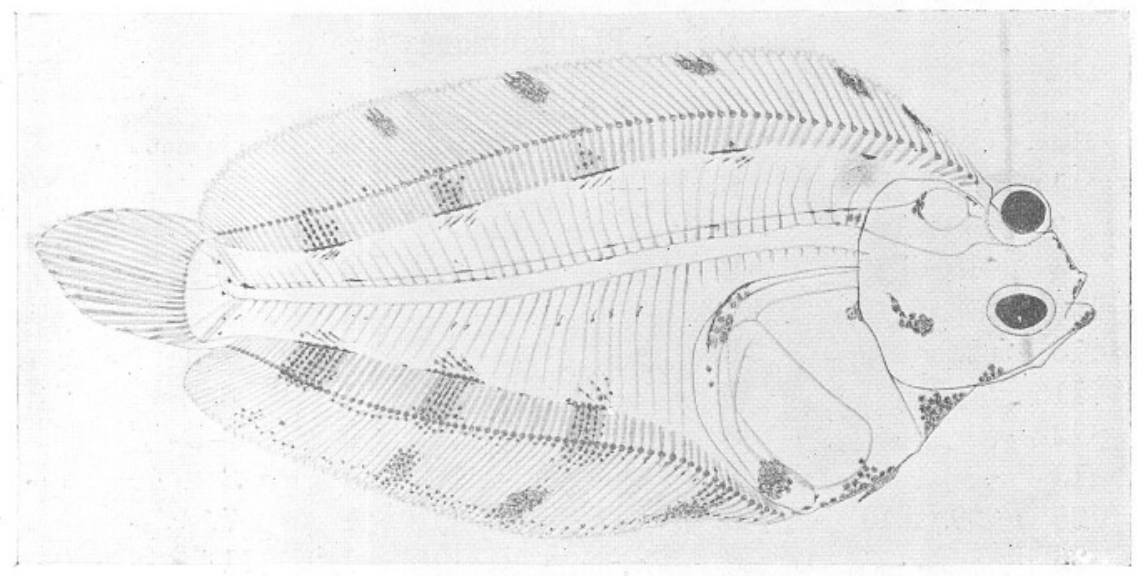

Fig. 2.-Metamorphosing stage of Pleuronectes microcephalus Don. Length $18.5 \mathrm{~mm}$., Del. E. Ford. Haul 48, Apparatus A, 2nd July, 1914.

The above figure is drawn from a mounted specimen. The numerical characters are definitely as follows :-

$$
\text { D. 88. A. } 75 \text {. Verebræ } 13+35 \text {. }
$$

There is nothing new to add to the descriptions of Holt (1893) and Petersen (1904). It is just a shade further advanced than Petersen's specimen of $18 \mathrm{~mm}$. (1904), and is about half-way through metamorphosis. The 
migrating eye has not quite reached the dorsal ridge and the pectorals have still got larval rays.

\section{P. platessa. Platce.}

The records of the cotton trawl $\mathrm{C}$ are few and cannot be taken as representative of the true state of things. The hauls with this net are not quite comprehensive enough in regard to locality. There is undoubtedly an abundance of the young in the Sound, even in the more brackish water, and they have been taken in large numbers along with young Turbot with hand nets worked from the shore in Whitsand Bay. The shallowness of the water in these localities prevented the Oithona from making the necessary captures.

\section{TABLE XXV.}

Apparatus A and B.

\section{Record of Pleuronectes sp.}

\begin{tabular}{|c|c|c|c|c|c|c|}
\hline $\begin{array}{l}\text { No. of } \\
\text { Haul. }\end{array}$ & Date. & Depth. & $\begin{array}{r}\text { P. } \\
\text { No. }\end{array}$ & da. & No. ${ }^{I}$ & $\begin{array}{l}\text { microcephalu } \\
\text { Size in } \mathrm{mm} \text {. }\end{array}$ \\
\hline 1 & 3.vii.19 & B. & - & - & 1 & 12 \\
\hline 3 & 9.vii.19 & M. & 1 & $12 \cdot 5$ & - & - \\
\hline 4 & 10.vii.19 & B. & 1 & 13 & 2 & $9-11$ \\
\hline 9 & 18.vii.19 & M.-B. & - & - & 1 & 8 \\
\hline 10 & 21.vii.19 & B. & - & - & 2 & $7-9$ \\
\hline 11 & ", & B. & - & - & 1 & 8 \\
\hline 12 & " & B. & - & - & 4 & $6-8$ \\
\hline 13 & , & B. & - & - & 1 & 8 \\
\hline 25 & 29.vii.19 & B. & - & - & 1 & 7 \\
\hline 26 & ", & B. & - & - & 1 & 11 \\
\hline 28 & 31.vii.19 & B. & - & - & 2 & $7-8$ \\
\hline 29 & 1.viii.19 & B. & - & - & 1 & 10 \\
\hline 64 & 9.ix.19 & B. & - & - & 1 & 18 \\
\hline 66 & 9.ix.19 & B. & - & - & 1 & 10 \\
\hline 80 & 25.ix.19 & B. & 1 & 56 & - & - \\
\hline
\end{tabular}




\section{TABLE XXVI.}

\section{Apparatus C.}

Record of Pleuronectes sp.

\begin{tabular}{|c|c|c|c|c|c|c|}
\hline No. of & Date. & Denth. & & imanda. & & atessa. \\
\hline Haul. & Date. & Depth, & No. & Size in $\mathrm{mm}$. & No. & Size in $\mathrm{mm}$. \\
\hline 5 & 26.viii.19 & B. & 7 & $35-54$ & - & - \\
\hline 17 & 12.ix.19 & B. & 1 & 35 & - & - \\
\hline 18 & , & B. & 1 & 65 & - & - \\
\hline 20 & 16.ix.19 & B. & 3 & $58-63$ & - & - \\
\hline 21 & ", & B. & 16 & $27-65$ & - & - \\
\hline 22 & , & B. & 26 & $44-145$ & 4 & $95-120$ \\
\hline 23 & , & B. & 54 & $41-135$ & 1 & 111 \\
\hline 24 & 18.ix.19 & B. & 42 & $48-68$ & 2 & $97-112$ \\
\hline 25 & , & B. & 8 & $42-60$ & 6 & $95-115$ \\
\hline 26 & 23.ix.19 & B. & 5 & $42-60$ & - & - \\
\hline 27 & , & B. & 47 & $26-62$ & - & - \\
\hline 28 & 29.ix.19 & B. & 1 & 32 & - & - \\
\hline 30 & , & B. & 6 & $44-79$ & - & - \\
\hline 31 & , & B. & 2 & $34-53$ & - & - \\
\hline
\end{tabular}

\section{SOLEIFORMES.}

\section{SOLEID}

Solea vulgaris Quens. Common Sole.

Only one post-larva, $4.5 \mathrm{~mm}$. in length, belonged to this species. This was taken in Haul 7, apparatus A, on 18th July, 1919. Post-larvæ of this species have never been taken in any numbers near Plymouth, and yet the adults are frequently trawled in the inner and outer Eddystone grounds and in the bays. The scarcity of the pelagic young is probably due, as also in the Plaice, to the maximum spawning period for Plymouth being in the earlier months of the year.

No early bottom stages were secured with the cotton trawl.

\section{Solea variegata, Don. Thickback.}

This is the species of the Genus Solea which occurs most frequently in the pelagic stage in the Plymouth area. The maximum number of post-larvæ has been recorded for May month, vide Allen (1917), who gives an average of 9.6 specimens per haul of 20 minutes for this month. The scarcity in numbers of the velagic young during the autumn of 1919 
is then easily explained. The records, however, prove that some adults spawn as late as July. The post-larvæ have been found chiefly in water of a total depth of over 20 fathoms.

\section{Determination of the Post-Larve.}

The number of fin rays and vertebræ for this species has been given by the various authors, ef. Holt and Byrne (1905) as :-

D 63-77. A 52-61. Vertebræ $9(10)+30(31)(32)$.

Petersen (1909) recorded a range of 46-60 anal rays in 6 post-larvæ, but the smaller number is obviously due to the fact that the full number of rays was not developed. An examination was made of 21 adults, 171-195 mm. in length, which were secured in the outer Eddystone grounds on 12th November, 1919. These were all females. The numerical results are here summarized :-

Dorsal Fin Rays.

$\begin{array}{lrrrrrrrrr}\text { No. of Fin Rays } & 68 & 70 & 71 & 72 & 73 & 75 & 76 & 77 & 78 \\ \text { No. of Specimens } & 2 & 3 & 1 & 2 & 6 & 2 & 3 & 1 & 1\end{array}$

Anal Fin Rays.

$\begin{array}{lllllllllll}\text { No. of Fin Rays } & 52 & 53 & 54 & 55 & 56 & 57 & 58 & 59 & 60 & 61\end{array}$

$\begin{array}{lllllllllll}\text { No. of Specimens } & 1 & 3 & 1 & 3 & 2 & 3 & 2 & 2 & 3 & 1\end{array}$

\section{Vertebræ.}

$\begin{array}{lrrr}\text { No. of vertebræ } & 40 & 41 & 42 \\ \text { No. of specimens } & 6 & 10 & 5\end{array}$

The range in number of rays and vertebræ is for these specimens

D $68-78$ (one more than the accepted number for this species)

A $52-61$

Vertebræ $40-42$.

The Plymouth post-larvæ, of which about 50 were stained and dehydrated, gave (with one exception) $10+30$ vertebræ, the exception being $10+31$.

The dorsal and anal rays showed, according to their development, a good deal of variation, but the number recorded in the larger specimens came well within the range noted above.

Petersen (1909) has described six post-larvæ, 6.9-18.3 mm., which undoubtedly belong to this species. Kyle (1913) seems to doubt Petersen's identification because of the absence of barred pigmentation, but this doubt can be ruled out, as this pigment character is wanting entirely in the pelagic young of this species, though it is present in the early bottom stages. Barred pigmentation is not a reliable index to specific 
identification. In Solea lascaris, for example, it is absent in the adult, but present in the pelagic young, vide Kyle (1913) and Clark (1914).

The striking feature of most of the Plymouth specimens is their comparatively greater breadth than Petersen's post-larvæ. They are more in agreement with Kyle's (1913) Mediterranean specimen. The protrusion of the abdomen is also characteristic of many but not all the post-larvæ.

There is no sign in any of the specimens of an air-bladder.

The post-larvæ range from 4 to $12 \cdot 3 \mathrm{~mm}$.

The Thickback is put on the market at Plymouth, but, owing chiefly to its small size, the fishery is not of great economic value. The adult occurs commonly on the inner and outer Eddystone grounds, but is trawled more frequently in the latter locality.

Description of Post-Larve.

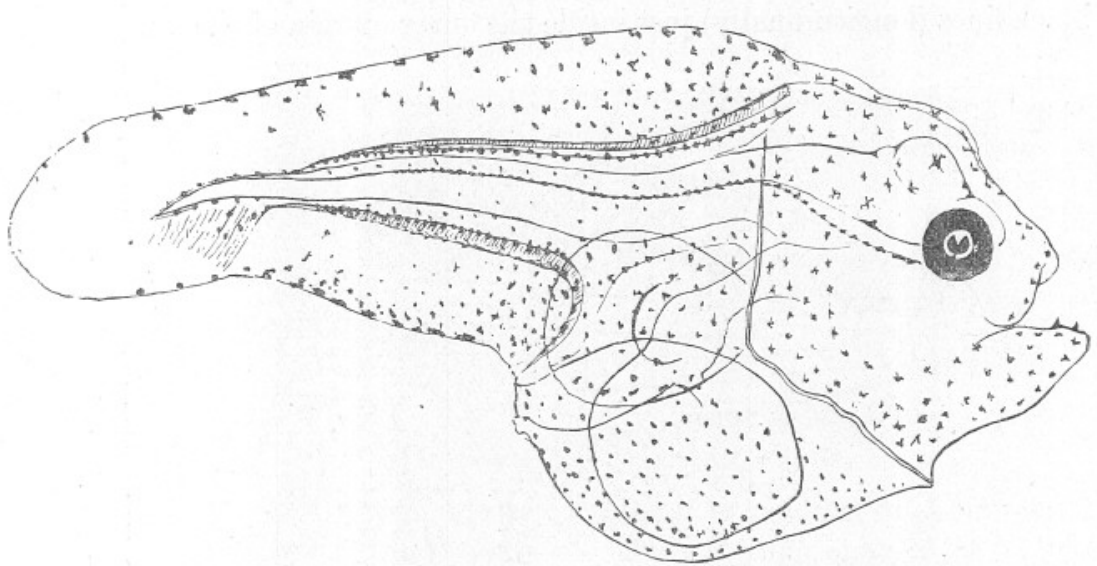

FIG. 8. - Solea variegata. Length $4 \mathrm{~mm}$. Hanl 10, Apparatus A, 19 th May, 1914. Del. E. Ford.

$4 \mathrm{~mm}$.- This is the smallest post-larva in the collection. It follows on Cunningham's $2.52 \mathrm{~mm}$. larva (1896), with the two longitudinal rows of large black stellate chromatophores along the dorsal and anal fin membranes. The eyes are perfectly symmetrical and about equal to the snout length, which is contained about $4 \frac{1}{2}$ times in the length of the head. The length of the head is about $\frac{1}{3}$ of the total length (including caudal). The anus is slightly nearer to the caudal than to the tip of the snout. The depth of the body is considerable, about half the total length. The pectorals are pedunculated and do not quite reach to the anus. The mid-brain is well arched and follows the dorsal contour of the head. Fin rays are not developed: interspines are just indicated. The notochord is straight. The pigmentation is characteristic. Five longitudinal 
rows dominate-one each on the margins of the dorsal and anal fin membranes, one each on the proximal ends of the dorsal and anal interspines and one along the dorsal half of the notochord. The rows along the dorsal interspines and on the notochord extend on to the head. These consist of stellate chromatophores which are slightly larger than the pigment cells which are scattered over the greater part of the bead and body. The number of chromatophores along the proximal ends of the interspines is much greater than in the other three species of Soles which occur at Plymouth, but it is difficult to count them accurately as the pigment cells appear to be drawn out longitudinally and to merge into each other. The pigment cells of the body appear, according to condition, as small stellate chromatophores or as small dots. They occur sparingly on the sub-orbital region, on the dorsal and anal fin membranes posteriorly and on the caudal. The colouration of the pectorals is confined to a ring of small black lines (longitudinally) just inside the outer margin of the fin.

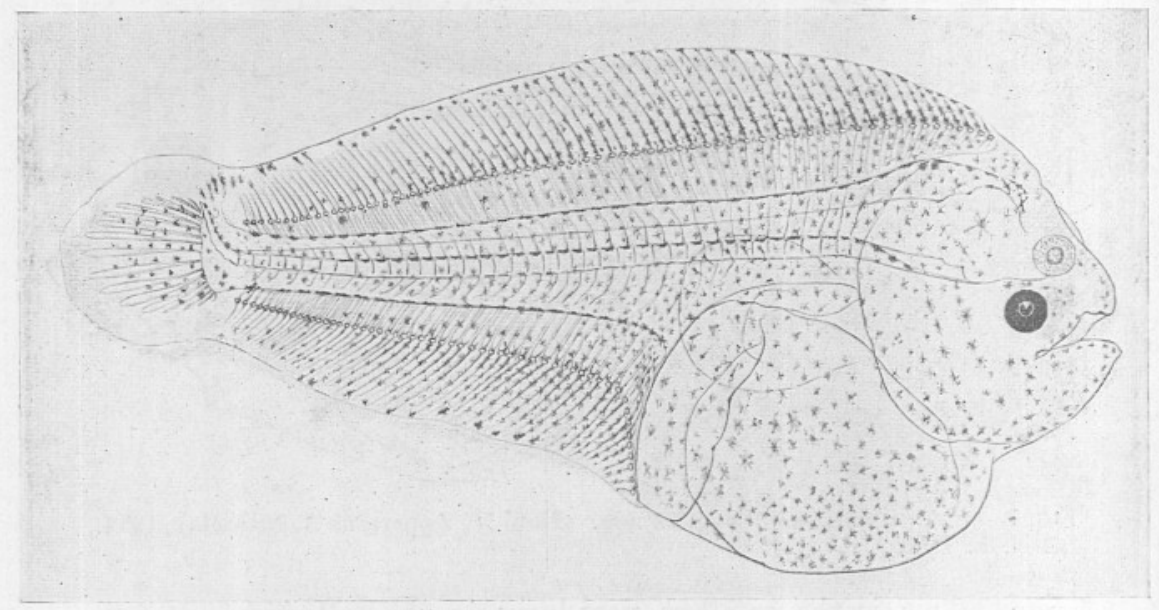

Fig. 4.-Solea variegata. Length $9 \mathrm{~mm}$. Haul 13, Apparatus A, 22nd May, 1914. Del. E. Ford.

$9 \mathrm{~mm}$.- Tip of snout to anus $4 \mathrm{~mm}$. Greatest depth of fish (including dorsal fin) $4 \cdot 25 \mathrm{~mm}$. Head four times in total length (including caudal). Diameter of eye less than length of snout, which is contained about four times in length of head. Pectorals reach to vertical through anus. They are pedunculated, rounded and about equally developed on both sides.

Fin Formula.-D ca. 69. A ca. 55. Vertebræ $10+30$.

The scheme of pigmentation is much the same as in the smaller specimen, but the rows of large chromatophores along the dorsal and anal fin margins are much subdued. The interspines are now well developed, 
but the fin rays are still short of their full length. The dorsal fin has extended on to the head. The left eye has moved forward and upward, but is still below the dorsal ridge. The notochord is bent upward. The pelvic fin has not yet appeared.

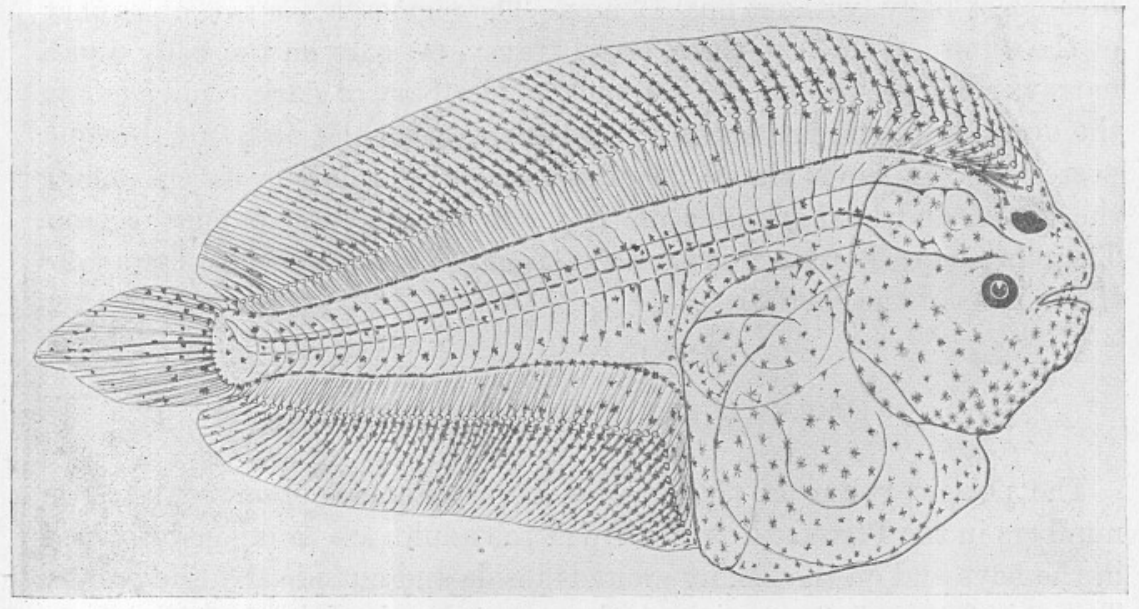

Fig. 5.-Solea variegata. Length $12.3 \mathrm{~mm}$. Haul 14, Apparatus A, 25th May, 1914. De]. E. FORD.

$12 \cdot 3 \mathrm{~mm}$.- Tip of snout to anus ca. $4.875 \mathrm{~mm}$. Greatest depth of body (excluding dorsal fin) ca. $5 \mathrm{~mm}$. Head about four times in total length (including caudal). Pectorals reach slightly beyond the vertical through the anus. The left eye has migrated round to the right side and the notch has closed up. The dorsal fin has moved forward, the first ray being vertically over the middle of the left (migrating) eye. The first interspine is roughly parallel to the outline of the brain and to it is attached the succeeding ray.

Fin Formula.-D 71. A 57. Vertebræ $10+30$.

No permanent rays are as yet developed in the pectorals, while the pelvics are just indicated. Metamorphosis is still far from being completed. The pigmentation is much the same as in the younger specimens. The two rows along the margins of the dorsal and anal fins have disappeared. The dorsal and anal fins are well covered along the rays with stellate chromatophores. The sub-orbital region is sparsely pigmented, as also are the interspinous regions, except for a short distance anteriorly, and on the middle of the body over the vertebral region. In all the specimens the pigment, as Petersen has remarked, is " distinctly scattered."

The smallest adolescent stage with typical adult characters is a speci- 
men of $42.5 \mathrm{~mm}$. (measured on a formalin specimen) which was captured at a depth of 29 fathoms, Eddystone bearing, S.W. 3 miles, on 5th March, 1914, in a small meshed pocket attached to the cod-end of the Oithona's otter trawl. The shape resembles Petersen's $18.3 \mathrm{~mm}$. post-larva. The head measures $9.5 \mathrm{~mm}$., tip of snout to anus $8 \mathrm{~mm}$. and the greatest breadth of body (without fins) $12 \mathrm{~mm}$. The pigmentation resembles that of the adult. There are three broad transverse bars on the body and a narrower one on the caudal peduncle. The bars of darker pigment on the dorsal and anal fins occur at regular intervals and are much broader posteriorly. There is almost a continuous series of darker blotches along the dorsal and anal margins of the body on the interspinous regions. There is a suggestion in this formalin specimen of a transverse bar across the middle of the caudal.

\section{Solea lutea (Risso). Solenette.}

The pelagic young of this species have not been observed in large numbers in the Plymouth area, though the adults are commonly trawled in the bays and on the fishing grounds inside and outside the Eddystone. Two post-larvæ, 5-6 mm. in length, were taken in July, 1919, between Rame Head and the Eddystone. The cotton trawl $\mathrm{C}$ captured 8 adults, 60-123 mm., in the shallower waters of Cawsand and Whitsand Bays and in deeper water between Rame Head and Eddystone.

The smallest early bottom stages observed by the writer were 3 specimens, $19.5-22.5 \mathrm{~mm}$. Two of these-19.5 and $21.5 \mathrm{~mm}$.-were secured from a depth of $7 \frac{1}{2}$ fathoms in a Mosquito tow net attached to one of the otter trawl boards in Whitsand Bay on 12th August, 1913, while the third specimen, $22.5 \mathrm{~mm}$., was brought up in the "D " net from a depth of 27 fathoms in locality $3 \frac{1}{2}$ miles W.S.W. from Rame Head on 2nd September, 1913.

The numerical characters were the following :-

\section{71-77. A 54-63. Vertebræ $9+29$.}

These specimens are similarly pigmented to the Mediterranean specimens, described by Kyle (1913). There are 9 to 10 large black blotches longitudinally along the dorsal and 5 to 6 along the anal interspinous regions. There are also 5 broad spots, equally spaced, along the vertebral column, the first at the edge of the operculum, the last on the penultimate vertebra. Lines of pigment are distributed along the rays of the dorsal and anal fins at fairly regular intervals, but there is only a suggestion of these occurring alternately at the base and at the tip. 


\section{SOlea lascaris. Risso.}

Only four post-larvæ, 8.5-13 mm. in length, were attributable to this species and these were taken at the end of September. Previous records are for July, August and September, but the production of the young in the neighbourhood is small. These four pelagic young fish were taken close inshore at the western entrance to the Sound. The species has a shallow water distribution.

The smallest early bottom stage is a specimen of $22.5 \mathrm{~mm}$. measured on 30th October, 1919. This was reared in the aquarium from a length of about $12 \mathrm{~mm}$., having been captured at that length in Haul 30, Apparatus C, 19th September, 1919, in locality Rame Head bearing E. by S., 3 miles. There is thus a growth of $10.5 \mathrm{~mm}$. in about four weeks.

On staining and clearing, the specimen gave quite definitely the following numerical characters :-

\section{84. A 69 . Vertebræ $9+37$.}

The specimen has completed its mecamorphosis, as proved by the forward movement of the dorsal fin on to the snout, and by the permanent rays being developed in the pectorals. The length of the head is contained about four times in the total length (including caudal): the greatest depth of the body (without fins) slightly less than three times. The pectorals are small, that of the left (blind) side being the smaller. The tumid nostril of the blind side is oval, rosette shaped, and large, being equal to about $\frac{3}{8}$ of the longitudinal diameter of the eye.

The pigmentation resembles that of the adult. The right (eyed) side is a felted mass of small black spots or stellate chromatophores with here and there an aggregation of large black stellate chromatophores. The barred pigmentation so characteristic of the post-larvæ has entirely disappeared. The blind side still supports a few large stellate chromatophores, but these are not prominent. Scales are developed all over the body and have one or more spines - the majority still being one-spined. Teeth are very well developed on the left (blind) side. This young fish follows on the metamorphosed specimen of $11.25 \mathrm{~mm}$., described and figured (Fig. 11) on page 371, Vol. X, No. 2, of this Journal.

\section{Solea sp.}

$\begin{array}{lcccc} & \text { S. vulgaris. } & \text { S. variegata. } & \text { S. lutea. } & \text { S. lascaris. } \\ \text { Spawning Period : } & \text { ii-vi } & \text { ii-vii. } & \text { iii-vii. } & \text { vi-viii. }\end{array}$




\section{TABLE XXVII.}

Apparatus A fand B.

Record of Solea sp.

\begin{tabular}{|c|c|c|c|c|c|c|c|c|c|c|}
\hline $\begin{array}{l}\text { No. of } \\
\text { Haul. }\end{array}$ & Date. & Depth. & No. & $\begin{array}{l}\text { vulgaris. } \\
\text { Size in nım. }\end{array}$ & No. & $\begin{array}{l}\text { variegata. } \\
\text { Size in } \mathrm{mm} \text {. }\end{array}$ & No. & $\begin{array}{l}\text { S. lutea. } \\
\text { Size in mm. }\end{array}$ & No. & $\begin{array}{l}\text { lascaris. } \\
\text { Size in } \mathrm{mm} .\end{array}$ \\
\hline 7 & 18.vii.19 & M. -B. & 1 & 4.5 & - & - & - & - & - & - \\
\hline 8 & ," & M. - B. & - & - & - & 一 & 1 & 6 & - & - \\
\hline 9 & , & M.-B. & - & - & 2 & $4-5$ & - & - & - & - \\
\hline 11 & 21.vii.19 & B. & - & - & 2 & $5-7.5$ & 1 & 5 & - & - \\
\hline 12 & ", & B. & - & - & 1 & 8 & - & - & - & - \\
\hline 25 & 29.vii.19 & B. & - & - & 4 & $5-9$ & - & - & - & - \\
\hline 26 & ," & B. & - & - & 1 & 7 & - & - & - & - \\
\hline 31 & 1.viii.19 & B. & - & - & 1 & 8 & - & - & - & - \\
\hline 32 & " & S. & - & - & 1 & 6 & - & - & - & - \\
\hline 37 & 5.viii.19 & B. & - & - & 1 & 5 & - - & - & - & - \\
\hline 78 & 25.ix.19 & B. & - & - & - & - & - & - & 1 & $9 \cdot 2$ \\
\hline 80 & $"$ & M. $-\mathrm{B}$, & - & - & - & - & - & - & 3 & $8 \cdot 5-13$ \\
\hline
\end{tabular}




\title{
TABLE XXVIII.
}

Apparatus C.

\author{
RECORD OF SOLEA sp.
}

\begin{tabular}{ccccccc}
$\begin{array}{c}\text { No. of } \\
\text { Haul. }\end{array}$ & Date. & Depth. & \multicolumn{2}{c}{$\begin{array}{c}\text { S. lutea. } \\
\text { Size in mm. }\end{array}$} & No. $\begin{array}{c}\text { S. lascaris. } \\
\text { Size in mm. }\end{array}$ \\
27 & $23 . i x .19$ & B. & 1 & 85 & - & - \\
28 & $29 . i x .19$ & B. & 1 & 60 & - & - \\
30 & " & B. & 5 & $60-97$ & 1 & 12 \\
31 & " & B. & 1 & 123 & - & -
\end{tabular}

\section{PERCOMORPHI.}

\section{PERCOIDEI.}

\section{SERRANID E.}

\section{Serranus cabrilla L. Sea-Perch.}

In Vol. X, No. 2, of this Journal published in. June, 1914, a footnote on page 392 recorded the identification of the young stages of this species, but descriptions and figures were not given as the series was far from being complete and many of the specimens were badly damaged. Meantime, however, Fage (1918) has given us excellent figures and descriptions of the young stages, ranging in length from 5-24 mm. These were all captured in the Mediterranean, but two post-larvæ, 9-11 mm., were taken in the English Channel off Cherbourg. The Channel specimens differ slightly in the arrangement of their pigmentation from those of the Mediterranean.

The production of the young in the Plymouth area is small. The post-larvæ were taken only in August and September, and these were scattered over the whole of the area outside the twenty-fathom contour line. Fage's description of a $5 \mathrm{~mm}$. fish holds good for those of $4 \mathrm{~mm}$. occurring in the present collection. There is no trace of the first dorsal fin, and it is not till almost $5.5 \mathrm{~mm}$. that a definite " thickening " appears at its base. Fig. 6 illustrates the point in question. At about $6 \mathrm{~mm}$. the third spine of the first dorșal fin becomes elongated as in Fig. 7, but it is an extremely delicate structure. In the later stages up to $9 \mathrm{~mm}$. the third spine becomes stouter and longer, being equal in length almost to the pelvics. The fin formula and number of vertebræ could only be counted with certainty in the larger post-larvæ from 8-9 $\mathrm{mm}$. and upwards, an observation which Fage has already noted.

\section{X 14. A III 7. Vertebræ $10+14$.}

The spinous and rayed sections of the dorsal and anal fins are concinuous as in the adult. The spine of the pelvic fin is just indicated; 
the second ray is the longest and is slightly longer than the third spine of the first dorsal. The pigmentation is peculiarly variable, a character which has been already noted for Channel post-larvæ and for the very early young, vide Hefford (1906), Fage (1918). The normal pigmentation appears to be as in Fig. 7. The variations in pigment are :-

1. Absence or reduction of large dorsal chromatophore with presence of large anal chromatophore.

2. Absence or reduction of large anal chromatophore with presence of large dorsal chromatophore.

3. Small chromatophores occasionally continuous along the base of the anal fin.

4. Single large black chromatophores occasionally present in the younger stages, at the beginning of the dorsal fin membrane and halfway along this membrane between the origin of the fin and the large dorsal chromatophore. The dorsal and posterior half of the abdominal cavity is always densely pigmented.

Spawning : vii-viii.

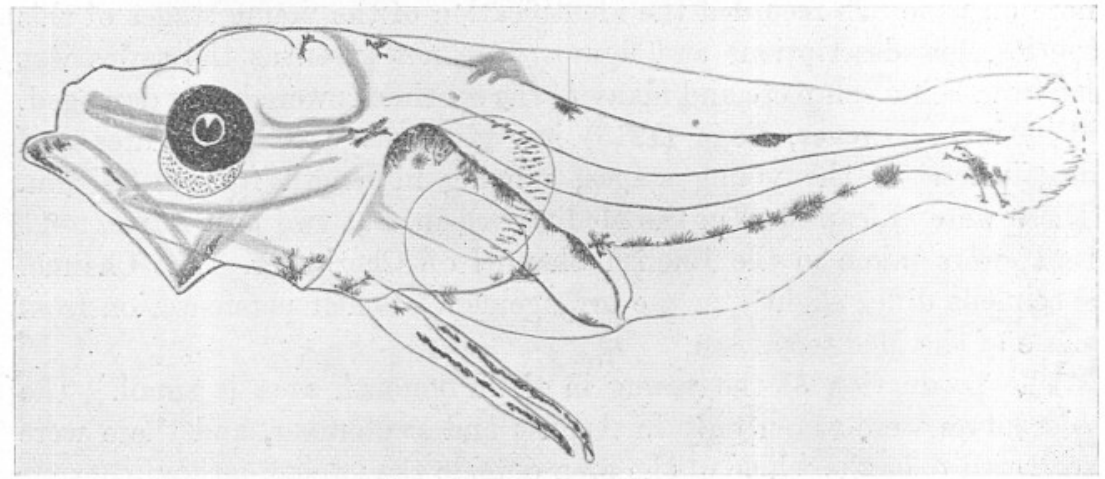

FIG. 6. - Serranus cabrilla L. Length $5.5 \mathrm{~mm}$. Haul 179A, Apparatus A, 29th September, Del. E. Ford. 1913.

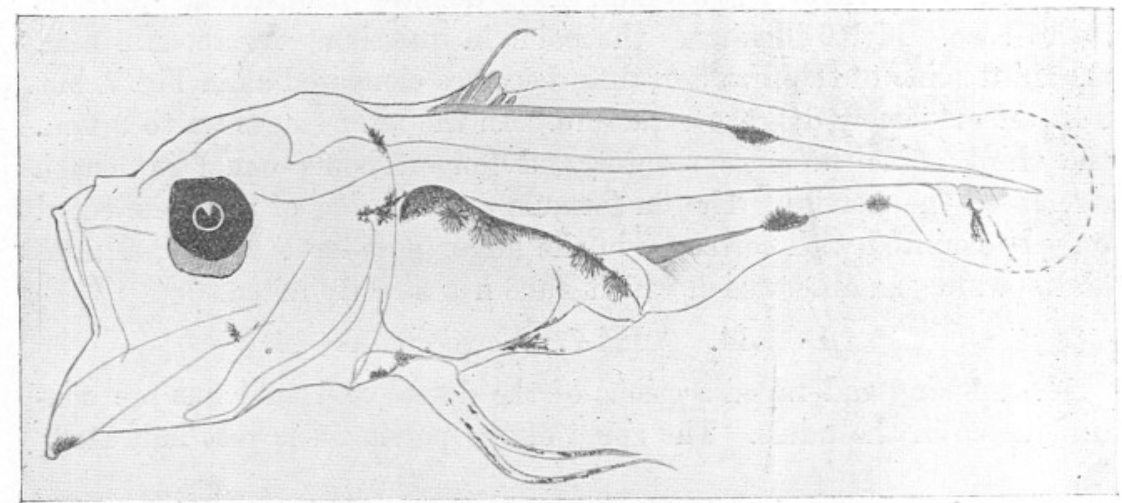

Fig. 7.-Serranus cabrilla L. Length ca. $6 \mathrm{~mm}$. Haul 105A, Apparatus A, 29th August, Del. E. For:D. 1913. 
These two figures illustrate the growth of the dorsal and anal fins.

At $5.5 \mathrm{~mm}$. the first dorsal is indicated by a thickening of the basethe second dorsal and anal have not made their appearance. At $6 \mathrm{~mm}$. the filiform spine of the first dorsal has grown out, while at the same time the base of the anal and second dorsal are beginning to show up. The filiform ray is extremely delicate.

There is nothing new to add to Fage's (1919) excellent descriptions of a complete series. The balancing organs are the elongated pelvics and first dorsal and the well-developed pectorals. The variation in pigmentalready remarked for Channel specimens-is well shown in Figs. 6 and 7.

\section{TABLE XXIX.}

Apparatus A and B.

No. of haul.
62
64
65
66
67
70
72

Recolid of Serranus cabrilla.

$\begin{array}{cccc}\text { Date. } & \text { Depth. } & \text { No. } & \text { Size in mm. } \\ 9 . \text { ix.19 } & \text { S. } & 3 & 7-8 \\ \text { " } & \text { B. } & 1 & 6 \cdot 5 \\ \text { " } & \text { S. } & 1 & 9 \\ \text { 10.ix.19 } & \text { B. } & 1 & 8 \\ 17 . i x .19 & \text { S. } & 3 & 8-9 \\ , " & \text { B. } & 1 & 7 \cdot 5 \\ & \text { B. } & 1 & 7\end{array}$

\section{TABLE XXX.}

Apparatus A.

ReCord of SERranus Cabrilla 1913.

\begin{tabular}{|c|c|c|c|c|}
\hline No. of haul. & Date. & Depth. & No. & Size in $\mathrm{mm}$. \\
\hline $57 \mathrm{~A}$ & 2.viii.13 & M. & 1 & 6 \\
\hline 99, & 26.viii.13 & M. & 8 & $4-6$ \\
\hline 105, & 29.viii.13 & M. & 6 & $4-6 \cdot 5$ \\
\hline 119, & 5.ix.13 & M. & 1 & 5 \\
\hline 142, & 15.ix.13 & B. & 1 & $5 \cdot 25$ \\
\hline 145, & " & M. & 1 & $4 \cdot 5$ \\
\hline 155, & 20.ix.13 & B. & 1 & $5 \cdot 5$ \\
\hline 156, & " & M. & 3 & $5 \cdot 5-6 \cdot 5$ \\
\hline 171, & 26.ix.13 & M. & 1 & 5 \\
\hline 172, & , & M. & 1 & $6 \cdot 5$ \\
\hline 174, & , & B. & 3 & $5-7$ \\
\hline 176, & " & B. & 1 & 5 \\
\hline 177, & , & S. & 2 & $5-5 \cdot 5$ \\
\hline 179, & 29.ix.13 & B. & 1 & $6 \cdot 5$ \\
\hline 180, & 30.ix.13 & M. & 1 & $4 \cdot 5$ \\
\hline
\end{tabular}




\section{PERCOIDEI.}

\section{CARANGID $\AA$.}

Caranx (Trachurus) trachures (L). Scad or Horse Mackerel.

The distribution of the post-larval Scads is general over the whole of the area investigated. The adolescent stages from 35 to $65 \mathrm{~mm}$. occurred in very shallow water close inshore in Cawsand Bay and Whitsand Bay East, though young fish of the same size were also captured between Rame Head, Eddystone and the 40 -fathom line. The average number per haul of the young fish trawls A and B was 2 for July, 6.8 for August and 1.8 for September.

The number of young stages taken during the three months in 1919 totalled 308 - a number far in excess of any previous year, and even surpassing the total number for all the previous years, 1906-1914, when only 99 specimens were secured. This increase in numbers during 1919 may be explained by the more systematic collecting with different meshed nets, but there is also a suggestion that the species varies in abundance in different years.

Spawning Period : vi-viii.

\section{TABLE XXXI.}

Apparatus A and B.

Record of CARANX trachurus.

\begin{tabular}{|c|c|c|c|c|}
\hline No. of haul. & Date. & Depth. & No. & Size in $\mathrm{mm}$. \\
\hline 9 & 18,vii.19 & M. $-\mathrm{B}$. & 2 & $5 \cdot 5-6 \cdot 5$ \\
\hline 12 & 21.vii.19 & B. & 4 & $4-8$ \\
\hline 20 & 29.vii.19 & B. & 1 & 14 \\
\hline 22 & " & M. & 1 & 4 \\
\hline 24 & , & B. & 26 & $3 \cdot 5-7$ \\
\hline 25 & , & B. & 12 & $4-6$ \\
\hline 26 & , & B. & 11 & $6-8$ \\
\hline 28 & 31.vii.19 & B. & 5 & $6 \cdot 5-9$ \\
\hline 30 & 1.viii. 19 & B. & 1 & $4 \cdot 5$ \\
\hline 32 & , & S. & 2 & $6-8$ \\
\hline 34 & 5.viii. 19 & B. & 4 & $5-6$ \\
\hline 35 & " & B. & 22 & $5-6$ \\
\hline 36 & ", & S. & 1 & 6 \\
\hline $37_{i}$ & , & B. & 49 & $3-6$ \\
\hline-38 & , & M. & 20 & $4-6$ \\
\hline 39. & , & B. & 23 & $4-6$ \\
\hline 42 & 7.viii.19 & B. & 1 & $6 \cdot 5$ \\
\hline
\end{tabular}


YOUNG STAGES OF TELEOSTEANS.

\begin{tabular}{|c|c|c|c|c|}
\hline $\begin{array}{c}\text { No. of haul. } \\
44\end{array}$ & $\begin{array}{c}\text { Date. } \\
\text { 8.viii.19 }\end{array}$ & $\begin{array}{l}\text { Depth. } \\
\text { M.-B. }\end{array}$ & $\begin{array}{l}\text { No. } \\
21\end{array}$ & $\begin{array}{c}\text { Size in } \mathrm{mm} . \\
4-6\end{array}$ \\
\hline 45 &, & M. & 2 & 7 \\
\hline 47 & , & B. & 16 & $4-6$ \\
\hline 48 & 11.viii.19 & B. & 11 & $4 \cdot 5-7$ \\
\hline 49 & ", & B. & 3 & $3-5$ \\
\hline 54 & 13.viii.19 & M. & 8 & $4-9$ \\
\hline 56 & 15.viii.19 & B. & 16 & $6-9$ \\
\hline 57 & 1.ix.19 & B. & 7 & $5-10$. \\
\hline 58 & , & B. & 2 & $6-7$ \\
\hline 59 & 3.ix.19 & S. & 2 & $14-24$ \\
\hline 60 & " & B. & 6 & $4 \cdot 5-25$ \\
\hline 62 & 9.ix.19 & S. & 2 & $8-11$ \\
\hline 64 & , & B. & 1 & 8 \\
\hline 65 & , & S. & 2 & $n \ldots$ \\
\hline 66 & , & B. & 4 & \\
\hline 67 & 10.ix.19 & S. & 4 & $8-14$ \\
\hline 68 & ," & M. & 3 & $8-11$ \\
\hline 70 & 17.ix.19 & B. & 1 & 10 \\
\hline 71 & ," & B. & 1 & 35 \\
\hline 72 & , & B. & 4 & $11 \cdot 5-16$ \\
\hline 73 & ," & B. & 1 & 19 \\
\hline 74 & 19.ix.19 & B. & 3 & $33-60$ \\
\hline 80 & 25.ix.19 & M. - B. & 3 & $45-50$ \\
\hline
\end{tabular}

\section{TABLE XXXII.}

Apparatus C.

ReCond of CaRANX trachurus

No, of hanl.

$\begin{array}{rl}7 & \text { 8.ix.19 } \\ 22 & 16 . i x .19 \\ 24 & 18 . i x .19 \\ 25 & \text { ". } \\ 27 & 23.19 .19\end{array}$

$\begin{array}{cc}\text { Depth. } & \text { No. } \\ \text { S. } & 1 \\ \text { B. } & 3 \\ \text { B. } & 4 \\ \text { B. } & 6 \\ \text { B. } & 3\end{array}$

B. 3
Size, in $\mathrm{mm}$.

19

ca. 35

$35-65$

$40-55$

$45-50$

\section{PERCOIDEII. MULLID A.}

Mullus surmuletus L." Red Mullet.

There are no records of thə pelagic young stages of this species in the young fish trawls A and B for 1919, but a few adolescent stages $58-60 \mathrm{~mm}$. 
in length were captured by the cotton trawl $\mathrm{C}$ in Whitsand Bay. The shrimp trawl also secured one of $51 \mathrm{~mm}$. in Cawsand Bay on 30th September, 1919. The average number per half-hour is one specimen, so that one may conclude that the young are not by any means numerous in the Plymouth area. The adults are now rarely captured in the neighbourhood, though the shore seine fishermen state that they were quite frequent a few years ago. Early young stages from 4.5 to $7.7 \mathrm{~mm}$. have been recorded by the writer for the years 1906-1913, in June, July and August, none being recorded for 1914.

Spawning Period: v-vii.

\section{TABLE XXXIII.}

Apparatus C.

Record of Mullus surmuletus L.

\begin{tabular}{|c|c|c|c|c|}
\hline No. of haul. & Date. & Depth. & No. & Size in mm. \\
\hline 20 & 16.ix.19 & B. & $\begin{array}{l}1 \\
1\end{array}$ & $\begin{array}{l}58 \\
60\end{array}$ \\
\hline $\begin{array}{l}22 \\
12\end{array}$ & & B. & 2 & ca. 60 \\
\hline 26 & 23.ix.19 & B. & 1 & 60 \\
\hline
\end{tabular}

Ammodytes tobianus L. Lesser Sand-eel. ” Lanceolatus, Lesauv. Greater Sand-Eel.

The material contains examples of these two species, and the characters by which they have been determined appear as a separate publication by Mr. E. Ford in the same volume of this Journal.

The spawning period for each species is still problematical, no examination having been made of the sexual condition of the adult nor have the demersal eggs been-secured. Lebour (1917) gives the following records for post-larvæ of A. tobianus from tow-nettings in the Sound :-

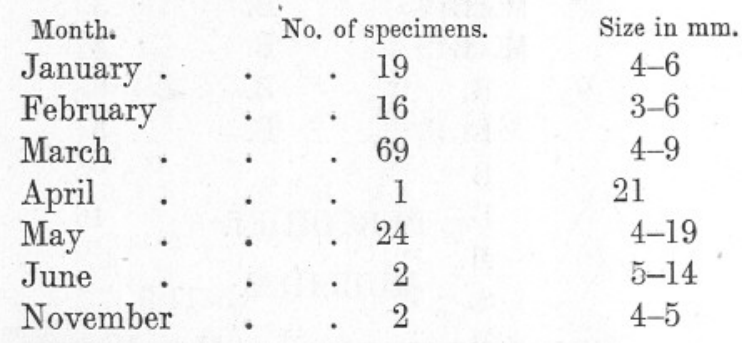

These suggest a winter and spring spawning with a probable maximum in spring, and also an extension to the warmer months. That som? individuals spawn in the summer months is proved by the 1919 records 
Post-larvæ of $A$. lanceolatus appear in greatest numbers in summer and early autumn, the months of greatest frequency being July and August. The pelagic young of both species are distributed generally over the whole area, both frequently occurring in the same haul. A. tobianus shows a greater frequency in inshore hauls, A. lanceolatus in offshore.

The average number of young fish per haul of the trawls A and B is as follows :-
A. tobianus
July.
August.
$0 \cdot 4$
September.
A. lanceolatus
- 11
$8 \cdot 2$
$3 \cdot 6$
$0 \cdot 64$

The September average of $A$. tobianus is due to the capture of early bottom stages. The small average for July and August for the same species and their absence from the pelagic hauls in September indicates that the main spawning is finished and that only a few individuals spawn during the summer.

The early bottom stages of $A$. lanceolatus were not secured with the cotton trawl, but 94 adolescent stages of $A$. tobianus, $110-140 \mathrm{~mm}$. in length, were taken in Whitsand Bay on sandy bottom at a depth of 4 to 6 fathoms.

Spawning Period :

A. tobianus.

(?) xii.-viii.

A. lanceolatus. vi.-viii.

\section{TABLE $\cdot$ XXXIV.}

Apparatus A and B.

Record of Ammodytes sp.

\begin{tabular}{|c|c|c|c|c|c|c|}
\hline \multirow{3}{*}{$\begin{array}{c}\text { No. of haul. } \\
2\end{array}$} & \multirow{3}{*}{$\begin{array}{c}\text { Date. } \\
\text { 7.vii.19 }\end{array}$} & \multirow{3}{*}{$\begin{array}{c}\text { Defth. } \\
\text { B. }\end{array}$} & \multicolumn{2}{|c|}{ A. tobianus. } & \multicolumn{2}{|c|}{ A. lanceolatus. } \\
\hline & & & No. & Size in $\mathrm{mm}$. & No. & Size in $\mathrm{mm}$. \\
\hline & & & 1 & 13 & 7 & $6 \cdot 5-21$ \\
\hline 3 & 9.vii.19 & M. & - & - & 5 & 14-19 \\
\hline 4 & 10.vii.19 & B. & - & 一 & 2 & $16-20$ \\
\hline 5 & 11.vii.19 & B. & 1 & 16 & - & - \\
\hline 6 & 18.vii.19 & M. -B. & 1 & $8 \cdot 5$ & 5 & $9-23$ \\
\hline 7 & , & M.-B. & 1 & 10 & 15 & $10-18$ \\
\hline 8 & $"$ & M.-B. & - & 一 & 3 & $12-14$ \\
\hline 9 & , & M.-B. & - & - & 32 & $8-13$ \\
\hline 10 & 21.vii.19 & B. & - & 一 & 8 & $9-18$ \\
\hline 11 & , & B. & - & 一 & 54 & $7-23$ \\
\hline 12 & , & B. & - & - & 20 & $5 \cdot 5-19$ \\
\hline 13 & , & B. & - & - & 46 & 9-19 \\
\hline 14 & 24.vii.19 & M. & - & - & 3 & $15-17$ \\
\hline 15 & , & S. & 5 & $8 \cdot 5-11 \cdot 5$ & 2 & $6 \cdot 5-21$ \\
\hline 16 & , & M. & 1 & $10 \cdot 5$ & 6 & $10 \cdot 5-18$ \\
\hline 17 & 28.vii.19 & M. & 1 & 9 & - & - \\
\hline 18 & , & M.-B. & 2 & $5-6$ & - & - \\
\hline 19 & " & M. & 2 & $6-8 \cdot 5$ & - & - \\
\hline
\end{tabular}


R. S. CLARK.

\begin{tabular}{|c|c|c|c|c|c|c|}
\hline \multirow{3}{*}{$\begin{array}{c}\text { No. of haul. } \\
20\end{array}$} & \multirow{3}{*}{$\begin{array}{c}\text { Date. } \\
\text { 29.vii.19 }\end{array}$} & \multirow{3}{*}{$\begin{array}{l}\text { Depth. } \\
\text { B. }\end{array}$} & \multicolumn{2}{|c|}{ A. tobianus. } & \multicolumn{2}{|c|}{ A. lanceolatus. } \\
\hline & & & No. & Size in $\mathrm{mm}$. & No. & \\
\hline & & & 1 & 18 & - & - \\
\hline 21 & ", & B. & - & - & 1 & 11 \\
\hline 22 & , & M. & - & - & 10 & $7-27$ \\
\hline 23 & , & S. & - & - & 1 & 9 \\
\hline 24 & , & B. & - & - & 25 & $8-22$ \\
\hline 25 & , & B. & 1 & 6 & 38 & $7-19$ \\
\hline 26 & , & B. & - & - & 36 & $7 \cdot 5-24$ \\
\hline 27 & 31.vii.19 & S. & 一 & - - & 1 & 12 \\
\hline 28 & , & B. & - & - & 22 & $10-19$ \\
\hline 29 & 1.viii.19 & B. & 1 & $6 \cdot 5$ & - & - \\
\hline 30 &, & B. & - & - & 3 & $7 \cdot 5-29$ \\
\hline 31 & , & B. & - & - & 8 & $10-18$ \\
\hline 32 & , & S. & 1 & 12 & 1 & 13 \\
\hline 33 & 5.viii.19 & M. & - & 一 & 1 & 14 \\
\hline 34 & " & B. & - & - & 53 & 8-14 \\
\hline 35 & , & B. & - & - & 17 & $7-13$ \\
\hline 37 & ", & B. & - & - & 21 & $8-16$ \\
\hline 38 & , & M. & - & - & 12 & $7 \cdot 5-18$ \\
\hline 39 & , & B. & - & - & 31 & $7-21$ \\
\hline 40 & 7.viii.19 & S. & 1 & 9 & - & - \\
\hline 41 & ", & M. & 4 & $6 \cdot 5-10$ & 2 & $9-18$ \\
\hline 42 & ", & B. & 1 & 7 & 1 & 14 \\
\hline 43 & , & B. & - & - & 3 & $19-20$ \\
\hline 44 & 8.viii.19 & M.-B. & - & - & 15 & $9-18$ \\
\hline 45 & " & M. & - & - & 9 & $10-18$ \\
\hline 46 & " & S. & - & - & 4 & 14-19 \\
\hline 47 & , & B. & - & - & 13 & $7 \cdot 5-16$ \\
\hline 48 & 11.viii.19 & B. & - & - & 4 & $8-16$ \\
\hline 51 & 13.viii.19 & M. & 1 & $9 \cdot 5$ & 1 & 25 \\
\hline 52 & ", & M. & - & - & 2 & $5-14 \cdot 5$ \\
\hline 53 & $"$ & M. & 3 & $6-8 \cdot 5$ & - & - \\
\hline 55 & 14.viii.19 & B. & - & - & 2 & $22-24$ \\
\hline 56 & 15.viii.19 & B. & - & - & 37 & $12-28$ \\
\hline 57 & 1.ix.19 & B. & - & - & 4 & $12-21$ \\
\hline 58 & ", & B. & - & - & 1 & 22 \\
\hline 59 & 3.ix.19 & S. & 1 & 9 & - & - \\
\hline 60 & ", & M. & - & - & 2 & $14-18$ \\
\hline 63 & 9.ix.19 & M. & - & - & 2 & $15-34$ \\
\hline 64 & 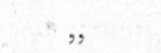 & B. & - & - & 4 & $11-25$ \\
\hline 66 & , & B. & - & - & $3^{\circ}$ & $12-16$ \\
\hline 74 & 19.ix.19 & B. & 83 & $110-12$ & - & - \\
\hline 75 & ", & B. & 6 & $115-14$ & - & - \\
\hline
\end{tabular}




\section{TABLE XXXV.}

\section{Apparatus C.}

\section{RECORD OF AMMODYTES.}

\begin{tabular}{ccccccc}
$\begin{array}{c}\text { No. of } \\
\text { Haul. }\end{array}$ & Date. & Depth. & No. $\begin{array}{c}\text { A tobianus. } \\
\text { Size in mm. }\end{array}$ & \multicolumn{2}{c}{$\begin{array}{c}\text { A lanceolatus. } \\
\text { So. }\end{array}$} & $\begin{array}{c}\text { Size in mm. } \\
6\end{array}$ \\
$3 . i x .19$ & B. & - & - & 2 & $11-15$ \\
22 & $16 . i x .19$ & B. & 4 & $110-120$ & - & - \\
24 & 18.ix.19 & B. & 1 & 120 & - & -
\end{tabular}

\section{CEPOLID A.}

\section{Cepola rubescens L. Red Band Fish.}

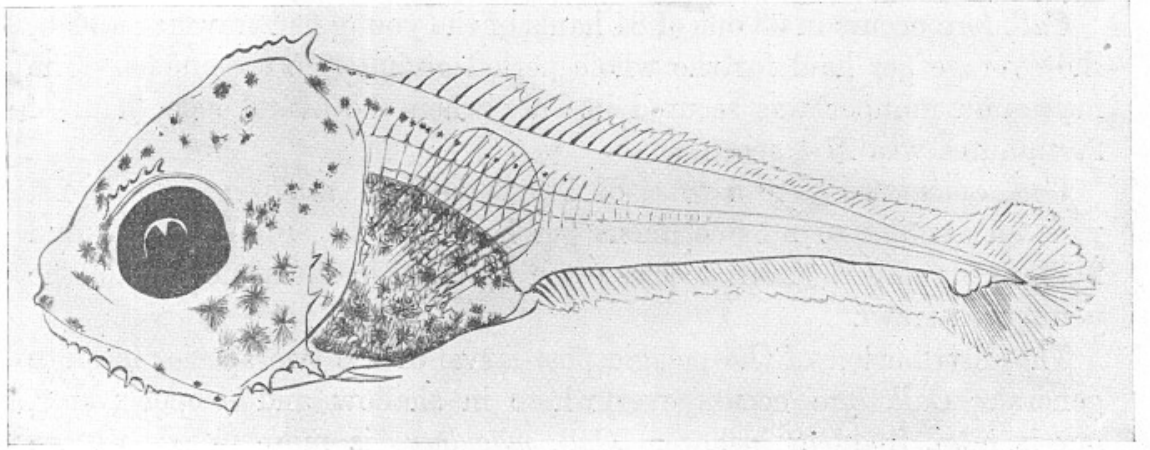

Fig. 8.-Cepola rubescens L. Length $7 \mathrm{~mm}$. Haul 62, Apparatus B, September 9th, Del. E. Ford. 1919.

A single post-larva of $7 \mathrm{~mm}$. belonging to this species was taken in Haul 62 (Surface) on 9th September,1919, over a total depth of 41 fathoms, The capture is interesting as being the first young stage which has been recorded from Plymouth waters. Fage (1918) gives several records of post-larvæ from 4.5 to $10 \mathrm{~mm}$. in length which were captured in the Mediterranean from July to September, and figures one of $6 \mathrm{~mm}$., while Lo Bianco (1909) gives interesting notes on the later post-larvæ, which take on the rose red colour at $20 \mathrm{~mm}$.

The Plymouth post-larva shows the characteristic denticulated supraoccipital and supra-orbitals. The lower surface of the mandible and the posterior and lower margins of the præopercula are also armed with spines. The head is broad and high. The specimen was stained and 
mounted and the fin rays were found as yet to be undeveloped, while only the first few vertebræ were calcified.

The adult is not uncommon in the vicinity of Plymouth and occurs in the captures of the otter trawls which are operated from small motor boats. A few adults, 385-505 mm., were caught in January, 1920, in Whitsand Bay by Looe boats. In these the reproductive organs were very minute.

Spawning Period : viii.

\section{CALLIONYMID $Æ$.}

Callionymus lyra (Li.) Dragonet. , Maculatus (Rafin.) Spotted Dragonet.

Two species are represented in the 1919 material, of which Call. lyra is much the commoner. Fage (1918) gives an excellent account of the young stages and a key for the identification of the species.

Call. lyra occurs in 53 out of 84 hauls of the young fish trawls A and B, the average per haul for the whole period giving 11.5 specimens. The maximum number was secured in July when the average per haul of 20 minutes was $27 \cdot 4$ specimens.

Call. maculatus gave a total of 149 post-larvæ, secured in 20 hauls, with an average of $2 \cdot 1$ specimens per haul in July, 0.7 in August and 2.5 for September. Both species often occurred in the same haul of the young fish trawl.

The distribution of the pelagic post-larvæ of the two species is quite general. Call. lyra occurs everywhere in shallow and deeper water, but is. more frequent inshore. Call. maculatus is more in accordance with a deeper water form, and most of the records are over greater depths.

The spawning period for the two species differs considerably. Call. lyra is spread over the first 8 months of the year, while Call. maculatus spawns only in the warmer months.

Young adult stages of both species were taken with the cotton trawl C. Here again Call. lyra occurs more frequently and practically everywhere, but more abundant close inshore in the bays. Only a few specimens of Call. maculatus were secured and all these were in deeper water.

$\begin{array}{ccc} & \text { C. lyra. } & \text { C. maculatus. } \\ \text { Spawning Period : } & \text { i-viii. } & \text { vi-viii. }\end{array}$


TABLE XXXVI.

Apparatus A and B.

Record of Callionymus sp.

\begin{tabular}{|c|c|c|c|c|c|c|}
\hline $\begin{array}{l}\text { No. of } \\
\text { Haul. }\end{array}$ & Date. & Depth. & & in $\mathrm{mm}$. & ${ }^{C .}$ & $\begin{array}{l}\text { raculatus. } \\
\text { Size in nun }\end{array}$ \\
\hline 1 & 3.vii.19 & B. & 2 & 4 & - & - \\
\hline 2 & 7.vii.19 & B. & 2 & $5-6$ & - & - \\
\hline 3 & 9.vii.19 & M. & 3 & $5-6$ & - & - \\
\hline 4 & 10.vii.19 & B. & 22 & $3-9$ & - & - \\
\hline 6 & 18.vii.19 & M.-B. & 25 & $3-8$ & - & - \\
\hline 7 & , & M.-B. & 8 & $4 \cdot 5-7 \cdot 5$ & - & - \\
\hline 8 & , & M.-B. & 32 & $3-8 \cdot 5$ & - & - \\
\hline 9 & , & M.-B. & 201 & $4-7$ & - & - \\
\hline 11 & 21.vii.19 & B. & 27 & $3-9 \cdot 5$ & - & - \\
\hline 12 & , & B. & 28 & $3-8$ & - & - \\
\hline 13 & , & B. & 1 & $3 \cdot 5$ & - & - \\
\hline 14 & 24.vii.19 & M. & 80 & $3-9$ & - & - \\
\hline 15 & , & S. & 21 & $3-8$ & - & - \\
\hline 16 & , & M. & 71 & $3 \cdot 5-8$ & - & - \\
\hline 17 & 28.vii.19 & M. & 24 & $4-10$ & - & - \\
\hline 18 & , & M.-B. & 19 & $3-9$ & - & - \\
\hline 19 & , & M. & 18 & $4 \cdot 5-8$ & - & - \\
\hline 21 & 29.vii.19 & B. & 1 & 3 & - & - \\
\hline 22 & ", & M. & 3 & $5-7$ & - & - \\
\hline 23 & , & S. & 4 & $4-6$ & - & - \\
\hline 24 & , & B. & 24 & $4-8$ & - & - \\
\hline 25 & $"$ & B. & 6 & $3-5$ & - & - \\
\hline 26 & , & B. & 66 & $4-11$ & 7 & $5-10$ \\
\hline 27 & - 31.vii.19 & S. & 1 & $3 \cdot 5$ & - & - \\
\hline 28 & , & B. & 135 & $4-10$ & 58 & $3 \cdot 5-9$ \\
\hline 29 & 1.viii.19 & B. & 28 & $4-8$ & - & - \\
\hline 30 & , & B. & 4 & $6-7$ & 6 & $4-6$ \\
\hline 31 & , & B. & 15 & $4: 5-9$ & - & - \\
\hline 32 & , & B. & 4 & $5-7$ & - & - \\
\hline 33 & 5.viii.19 & M. & 1 & 5 & - & - \\
\hline 34 &, & B. & 8 & $4-6$ & - & - \\
\hline 35 & ", & B. & 7 & $3-6.5$ & 1 & 6 \\
\hline 37 & , & B. & 11 & $2 \cdot 5-7$ & 2 & $6-7$ \\
\hline 38 & $"$ & M. & 6 & $4-6$ & - & , - \\
\hline 39 & , & B. & 11 & $3 \cdot 5-8$ & - & - \\
\hline 41 & 7.viii.19 & M. & 2 & $5 \cdot 5-7$ & - & - \\
\hline
\end{tabular}


R. S. CLARK.

\begin{tabular}{|c|c|c|c|c|c|c|}
\hline $\begin{array}{l}\text { No. of } \\
\text { Haul. }\end{array}$ & Date. & Depth. & No. & $\begin{array}{l}\text { lyra. } \\
\text { Size in mm. }\end{array}$ & No. & $\begin{array}{l}\text { maculatus. } \\
\text { Size in mm. }\end{array}$ \\
\hline 43 & 7.viii.19 & B. & 12 & 4-7 & - & - \\
\hline 44 & 8.viii.19 & M.-B. & 18 & 4-6 & 4 & $5-6$ \\
\hline 45 & , & M. & - & - & 1 & 7 \\
\hline 46 & $"$ & S. & 1 & $4 \cdot 5$ & - & - \\
\hline 47 & , & B. & 2 & $5-6$ & 2 & $5-6 \cdot 5$ \\
\hline 48 & 11.viii.19 & B. & 4 & $5-9$ & 1 & 8 \\
\hline 49 & , & B. & 1 & 5 & - & - \\
\hline 52 & 13.viii.19 & M. & 1 & $7 \cdot 5$ & - & - \\
\hline 54 & , & M. & 1 & $8 \cdot 5$ & 1 & 8 \\
\hline 55 & 14.viii.19 & B. & 1 & $9 \cdot 5$ & 2 & $5 \cdot 5-7$ \\
\hline 56 & 15.viii.19 & B. & 5 & $5-7$ & 1 & 6 \\
\hline 60 & 3.ix.19 & M. & 1 & 4 & - & - \\
\hline 63 & 9.ix.19 & M. & - & - & 11 & $7-10$ \\
\hline 64 & ", & B. & 1 & 11 & 30 & $6-12$ \\
\hline 65 & ", & S. & - & - & 7 & $6-8$ \\
\hline 66 & , & B. & - & - & 6 & $6-10$ \\
\hline 68 & 10.ix.19 & M. & - & - & 5 & $7-11 \cdot 5$ \\
\hline 73 & 17.ix.19 & B. & - & - & 2 & $15-29$ \\
\hline 77 & 25.ix.19 & B. & 1 & 82 & - & - \\
\hline 78 & , & B. & - & - & 1 & 9 \\
\hline 79 & , & M.-B. & - & - & 1 & 9 \\
\hline 81 & 29.ix.19 & B. & 1 & 138 & - & - \\
\hline
\end{tabular}

\section{TABLE XXXVII.}

Apparatus C.

Record of Callionymus sp.

\begin{tabular}{rcccccc}
$\begin{array}{c}\text { No. of } \\
\text { Haul. }\end{array}$ & Date. & Depth. & \multicolumn{2}{c}{ C. lyra. } & & C. maculatus. \\
4 & 25.viii.19 & B. & 36 & $33-67$ & - & - \\
5 & 26. viii.19 & B. & 4 & $45-68$ & - & - \\
6 & $3 . i x .19$ & B. & 1 & 170 & - & - \\
18 & 12.ix.19 & B. & 6 & $35-140$ & 5 & $70-120$ \\
21 & $16 . i x .19$ & B. & 7 & $50-82$ & - & - \\
22 & ", & B. & 8 & $40-82$ & - & - \\
23 & B. & B. & 26 & $42-85$ & - & - \\
24 & 18.ix.19 & B. & 30 & $40-85$ & - & - \\
26 & $23 . i x .19$ & B. & 30 & $46-145$ & - & - \\
27 & ," & B. & 318 & $45-140$ & - & - \\
28 & $29 . i x .19$ & B. & 1 & 76 & - & - \\
30 & " & B. & 9 & $35-255$ & 3 & $82-98$ \\
31 & " & B. & 1 & 81 & 1 & 100
\end{tabular}




\section{LABRID $A$.}

Labrus bergylta Asc. Mix́tus (L.) Ctenolabrus Rupestris (L.) Crenilabrus melops (L.) Centrolabrus exoletus L.

The five species of Wrasses show a considerable production of the young pelagic fry, nine specimens per haul for the three months in 1919. They occur most abundantly in July when the average per haul gives 18.7 specimens. Five species are represented in the collection, three of which seem to be imperfectly known in the younger pelagic stages, these being recorded here as Labrid types. A separate paper will be published shortly by one of us on the identification of the doubtful species. The later stages, however, where the adult characters are developed are easy to identify, and all five species occur in the cotton trawl collection. These later stages are developed in comparatively shallow water close inshore. They are abundant in the Zostera bed of Cawsand Bay.

Coris julis (L.) occurs in the adult stage in the neighbourhood, but its young stages have not been observed.

\section{TABLE XXXVIII.}

\section{Apparatus A and B.}

\section{RECORD OF LABRID叛.}

\begin{tabular}{|c|c|c|c|c|c|c|c|c|}
\hline \multirow{2}{*}{$\begin{array}{c}\text { No. of } \\
\text { Haul. } \\
1\end{array}$} & \multirow{2}{*}{$\begin{array}{c}\text { Date. } \\
\text { 3.vii.19 }\end{array}$} & \multirow{2}{*}{$\begin{array}{l}\text { Depth. } \\
\text { B. }\end{array}$} & \multicolumn{2}{|c|}{$\begin{array}{l}\text { Labrus mixtus. } \\
\text { No. Size in mm. }\end{array}$} & \multicolumn{2}{|c|}{$\begin{array}{c}\text { Ctenolabrus } \\
\text { rupestris. } \\
\text { No. Size in mm. }\end{array}$} & \multicolumn{2}{|c|}{$\begin{array}{l}\text { Labrid types. } \\
\text { No. Size in mm }\end{array}$} \\
\hline & & & 5 & $10-11$ & - & - & 7 & $6-7$ \\
\hline 2 & 7.vii.19 & B. & - & - & 1 & 10 & 19 & $5-8$ \\
\hline 3 & 9.vii.19 & M. & - & - & - & 一 & 1 & 5 \\
\hline 6 & 18.vii.19 & M.-B. & - & - & - & - & 22 & $5-10$ \\
\hline 7 & ", & M.-B. & 4 & $7-9$ & - & - & 27 & $4 \cdot 5-9 \cdot 5$ \\
\hline 8 & ", & M. -B. & - & - & - & - & 14 & $4 \cdot 5-7$ \\
\hline 9 & $"$ & M.-B. & 3 & $8-9 \cdot 5$ & 1 & 8 & 2 & $4-5$ \\
\hline 10 & 21.vii.19 & B. & - & - & - & - & 1 & 4 \\
\hline 11 & , & B. & - & - & - & - & 7 & $4 \cdot 5-8$ \\
\hline 12 & , & B. & 1 & 9 & - & - & 11 & $5-7$ \\
\hline 13 & 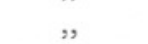 & B. & 7 & $8-12$ & 3 & 10 & 3 & $6 \cdot 5-8 \cdot 5$ \\
\hline 14 & 24.vii.19 & M. & 4 & $9-10$ & - & - & 190 & $5-8$ \\
\hline
\end{tabular}




\begin{tabular}{|c|c|c|c|c|c|c|c|c|}
\hline $\begin{array}{l}\text { No. of } \\
\text { Haul. }\end{array}$ & Date. & Depth. & $\begin{array}{l}L a \\
\text { No. }\end{array}$ & $\begin{array}{l}\text { us mixtus. } \\
\text { ize in } \mathrm{mm} \text {. }\end{array}$ & & $\begin{array}{l}\text { olabrus } \\
\text { pestris. } \\
\text { z mm. }\end{array}$ & & $\begin{array}{l}\text { Wid types. } \\
\text { Size in } \mathrm{mr}\end{array}$ \\
\hline 15 & 24.vii.19 & s. & - & - & - & - & 62 & $4-8$ \\
\hline 16 & ," & M. & 1 & 8 & - & - & 18 & $5 \cdot 5-9$ \\
\hline 17 & 28.vii.19 & M. & - & - & 2 & $9-9 \cdot 5$ & 32 & $4 \cdot 5-9$ \\
\hline 18 & ", & M.-B. & - & - & 2 & $7-8$ & 39 & $4-8$ \\
\hline 19 & " & M. & - & - & - & - & 28 & $4-7 \cdot 5$ \\
\hline 20 & 29.vii.19 & B. & - & - & - & - & 12 & $5-8$ \\
\hline 21 & , & B. & - & - & 1 & 8 & 9 & $4-7$ \\
\hline 22 & , & M. & - & - & 3 & $7-9$ & 5 & $4-6$ \\
\hline 23 & , & S. & - & - & 1 & 8 & - & - \\
\hline 24 & , & B. & - & - & 2 & $7-8$ & - & - \\
\hline 25 & " & B. & - & - & 1 & $7 \cdot 5$ & - & - \\
\hline 26 & ", & B. & - & - & 8 & $7-9$ & - & - \\
\hline 28 & 31.vii.19 & B. & 1 & 6 & 3 & $9-10$ & 1 & 8 \\
\hline 29 & 1.viii.19 & B. & - & - & - & - & 35 & $4-7$ \\
\hline 30 & , & B. & - & - & - & - & 6 & $4 \cdot 7-7 \cdot 5$ \\
\hline 31 & ", & B. & - & - & 6 & $8-9$ & - & - \\
\hline 32 & ", & S. & - & - & 2 & $7-9$ & 1 & 6 \\
\hline 33 & 5.viii.19 & M. & - & - & - & - & 8 & $5-7$ \\
\hline 34 & , & B. & - & - & - & - & 1 & 5 \\
\hline 35 & ", & B. & - & - & - & - & 2 & 5 \\
\hline 39 & , & B. & - & - & . 2 & $6 \cdot 5-7$ & 5 & $4-6$ \\
\hline 40 & 7.viii.19 & S. & - & - & - & - & 4 & $7-7 \cdot 5$ \\
\hline 41 & , & M. & - & - & - & - & 50 & $4-9$ \\
\hline 42 & , & B. & - & - & - & - & 19 & $4-8$ \\
\hline 43 & , & B. & - & - & 1 & 9 & 16 & $4-9$ \\
\hline 44 & 8.viii.19 & M.-B. & - & - & - & - & 1 & 4 \\
\hline 47 & ," & B. & - & - & 一 & - & 1 & 5 \\
\hline 49 & 11.viii.19 & B. & - & - & - & - & 10 & $5-7$ \\
\hline 50 & 13.viii.19 & M. & - & - & - & - & 2 & $7-8$ \\
\hline 51 &, & M. & - & - & 1 & 11 & 2 & $6 \cdot 5-9$ \\
\hline 52 & ", & M. & - & - & - & - & 10 & $4 \cdot 5-9$ \\
\hline 53 & ", & M. & - & - & - & - & 2 & $6-7 \cdot 5$ \\
\hline 54 & , & M. & - & - & - & - & 1 & 8 \\
\hline 67 & 10.ix.19 & S. & - & - & - & - & 1 & 11 \\
\hline 77 & 25.ix.19 & B. & - & - & 3 & $32-40$ & - & - \\
\hline
\end{tabular}




\section{TABLE XXXIX.}

\section{Apparatus C.}

\section{RECORD OF LABRIDÆ.}

\begin{tabular}{|c|c|c|c|c|c|c|c|c|c|c|c|c|}
\hline $\begin{array}{l}\text { No. of } \\
\text { Haul. }\end{array}$ & Date. & Depth. & $\begin{array}{l}C e \\
\text { No. }\end{array}$ & $\begin{array}{l}\text { extrolabrus } \\
\text { exoletus. } \\
\text { Size in mm. }\end{array}$ & $\begin{array}{l}\text { Lab } \\
\text { No. }\end{array}$ & $\begin{array}{l}\text { us mixtus. } \\
\text { Size in mm. }\end{array}$ & $\begin{array}{l}\text { Lal } \\
\text { No. }\end{array}$ & $\begin{array}{l}\text { rus bergylta } \\
\text { Size in mm. }\end{array}$ & $\begin{array}{r}C t \\
{ }^{r} \\
\text { No. }\end{array}$ & $\begin{array}{l}\text { nolabrus } \\
\text { ipestris } \\
\text { Size in mm. }\end{array}$ & $\begin{array}{l}\text { Creni } \\
\text { No. }\end{array}$ & $\begin{array}{l}\text { abrus melops. } \\
\text { Size in mm. }\end{array}$ \\
\hline 4 & 25.viii.19 & B. & - & - & 2 & $39-44$ & 2 & $30-37$ & 25 & 30-39 & 14 & $25-38$ \\
\hline 5 & 26.viii.19 & B. & 2 & $28-37$ & 2 & $36-37$ & 2 & $27-37$ & 8 & $29-37$ & 2 & $22-23$ \\
\hline 27 & 23.ix.19 & B. & - & - & - & - & 一 & - & 2 & $35-43$ & 5 & $43-59$ \\
\hline 29 & 29.ix.19 & B. & - & - & - & - & - & - & 1 & 98 & - & - \\
\hline
\end{tabular}




\title{
TRACHINID E.
}

\author{
Trachinus vipera, C. \& V. Lesser Weever. \\ DRACO, L. \\ Greater Weever.
}

The pelagic young of Trachinus vipera (Lesser Weever) are distributed generally over the whole of the area investigated. Out of 84 hauls this species occurred in 52, but with an average of only 3 fish per haul. The total number examined was 252 with a range in length from 3 to $11 \mathrm{~mm}$. The maximum number (149) was in July, and the pelagic stages were still being got at the end of September.

Adolescent stages from 59 to $98 \mathrm{~mm}$. were taken in shallow water with the cotton trawl C in Whitsand Bay. Several hundreds were captured with the shrimp trawl in the same locality in 4-6 fathoms, and were transferred alive to the aquarium tanks, where they seemed to come to rest on the bottom and to lie partly on their sides. Their habitat appears to be on sandy bottoms, where they can rest partly hidden in the sand.

Pelagic young of Trachinus draco (Greater Weever) occurred very sparingly and outside the 20 -fathom line. Its distribution appears to be more in deeper water. The records extend from end of July to the middle of September when they disappear from the pelagic hauls, the largest post-larva being $12 \mathrm{~mm}$. in length.

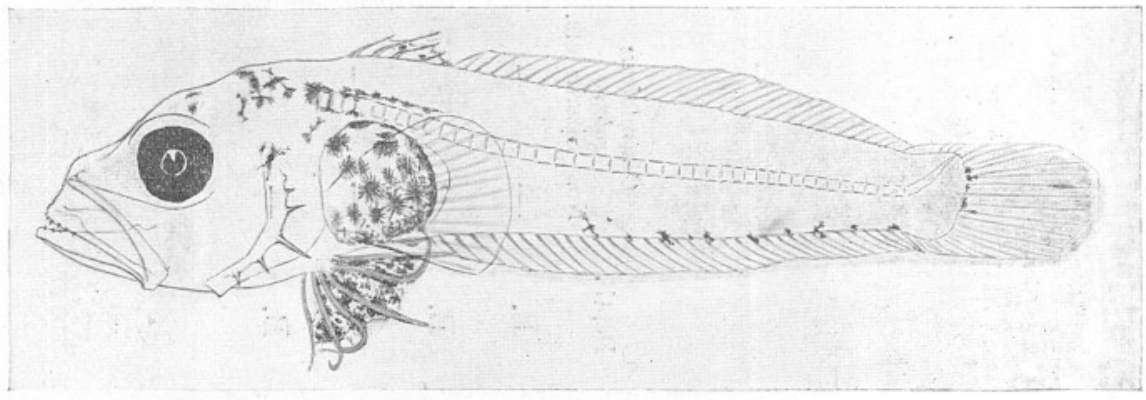

Fig. 9.-Trachinus draco L. Length $12 \mathrm{~mm}$. Haul 65, Apparatus B, September 9th, Del. E. Ford. 1919.

The above figure is drawn from a stained and mounted specimen whose length in formalin was $12 \mathrm{~mm}$. The præmaxillæ are shown protruded. The head is contained from $3 \frac{1}{2}$ to $3 \frac{3}{4}$ times in total length, the greatest depth about 5 times. The diameter of the 
eye is slightly less than the snout length. The numerical characters are :-

\section{VI 31.}

A 32 .

Vertebræ $11+31$.

The first dorsal so far is not well defined - five of the spines can be counted quite definitely - the first three being close together and separated by a wider space from the fourth. The two dorsal fins are connected by a membrane. Another specimen of $11 \mathrm{~mm}$. gives D VI $31 \mathrm{~A} 30$. The vertebræ are definitely 42. Fage (1919), p. 122, gives similar numbers for a $9.5 \mathrm{~mm}$. fish, but there is obviously a printer's error in the number of vertebræ, which should read $11+31$.

The pigmentation is well shown in the above figure. Two black spots appear on the first dorsal. The abdominal region and the pelvic fins are densely pigmented with black stellate chromatophores. There is a row of chromatophores usually six or more along the base of the anal fin, while an aggregation of black chromatophores is present at the base of the mid-caudal rays.

$\begin{array}{ccc} & \text { T. vipera. } & \text { T. draco. } \\ \text { Spawning Period : } & \text { iv-viii. } & \text { vi-viii. }\end{array}$

\section{TABLE XL.}

Apparatus A and B.

\section{RECoRd of Trachinus sp.}

\begin{tabular}{|c|c|c|c|c|c|c|}
\hline No. of & Date. & Denth & & himus vipera & & inus dra \\
\hline & & Dopent. & & Size in mm. & No. & Size in $\mathrm{m}$ \\
\hline 2 & 7.vii.19 & B. & 3 & $5-6$ & - & - \\
\hline 4 & 10.vii.19 & B. & 7 & $3-5$ & - & 一 \\
\hline 6. & 18.vii.19 & M. - B. & 7 & $4 \cdot 5-6$ & - & - \\
\hline 7 & , & M.-B. & 10 & $5-6$ & - & - \\
\hline 8 & , & M. - B. & 13 & $4-10$ & - & 一 \\
\hline 9 & , & M. - B. & 32 & $4-8$. & - & - \\
\hline 11 & 21.vii.19 & B. & 6 & $5-7$ & - & - \\
\hline 12 & , & B. & 3 & $7-7 \cdot 5$ & - & - \\
\hline 13 &,$\quad \cdots$ & B. & 15 & $4 \cdot 5-7$ & - & - \\
\hline 14 & 24.vii.19 & M. & 18 & $5-9$ & - & 一 \\
\hline 15 & , & S. & 9 & $4 \cdot 5-9 \cdot 5$ & - & - \\
\hline 16 &, & M. & 2 & $5 \cdot 5-6 \cdot 5$ & - & - \\
\hline 17 & 28.vii.19 & M. & 2 & $7-11$ & - & - \\
\hline
\end{tabular}


R. S. CLARK.

\begin{tabular}{|c|c|c|c|c|c|c|}
\hline No. of & & & Tra & inus vipera. & & achinus drace \\
\hline Haul. & Date. & Depth. & No. & Size in $\mathrm{mm}$. & No. & Size in $\mathrm{mn}$ \\
\hline 18 & 28.vii.19 & M.-B. & 3 & $6-9$ & - & - \\
\hline 19 & , & M. & 4 & $6-9 \cdot 5$ & - & - \\
\hline 21 & 29.vii.19 & B. & 2 & $4-5$ & 1 & 5 \\
\hline 22 &, & M. & 2 & $4-6$ & - & - \\
\hline 23 & , & S. . & 1 & $8 \cdot 5$ & - & - \\
\hline 24 & , & B. & 4 & $5-7$ & - & - \\
\hline 25 & , & B. & 4 & $5-6$ & - & - \\
\hline 26 & , & B. & 2 & $4-6 \cdot 5$ & - & - \\
\hline 29 & 1.viii.19 & B. & 2 & $6-7$ & - & - \\
\hline 30 &, & B. & 1 & 5 & - & - \\
\hline 32 & " & S. & 3 & $5 \cdot 5-7 \cdot 5$ & - & - \\
\hline 33 & 5.viii.19 & M. & 3 & $5-7$ & - & - \\
\hline 34 &, & B. & 7 & $4-7$ & 1 & 6 \\
\hline 35 & $"$ & B. & 4 & $4 \cdot 5$ & 1 & $4 \cdot 5$ \\
\hline 37 & ", & B. & 2 & $5-6$ & - & - \\
\hline 39 & , & B. & 8 & $4 \cdot 5-7$ & - & - \\
\hline 40 & 7.viii.19 & S. & 7 & $4 \cdot 5-8$ & - & - \\
\hline 41 & , & M. & 3 & $4 \cdot 5-7$ & - & - \\
\hline 42 & , & B. & 2 & $4 \cdot 5-6$ & 1 & 6 \\
\hline 43 & , & B. & 2 & $5-7$ & - & - \\
\hline 44 & 8.viii.19 & M.-B. & 1 & 6 & - & - \\
\hline 46 . & , & S. & 2 & 7 & - & - \\
\hline 48 & 11.viii.19 & B. & 8 & $4-7$ & - & - \\
\hline 49 & , & B. & 1 & 5 & - & - \\
\hline 51 & 13.viii.19 & M. & 1 & $4 \cdot 5$ & - & - \\
\hline 52 & Len & M. & 5 & $5 \cdot 5-6$ & - & - \\
\hline 55 & 14.viii.19 & B. & 1 & 8 & - & - \\
\hline 56 & 15.viii.19 & B. & 1 & 8.5 & - & - \\
\hline 58 & 1.ix.19 & B. & 2 & $6-9$ & - & - \\
\hline 62 & 9.ix.19 & S. & 7 & $7-10$ & - & - \\
\hline 64 & , & B. & 1 & 9 & - & - \\
\hline 65 & , & S. & 1 & 7 & 3 & $8-12$ \\
\hline 66 & ", & B. & - & - & 1 & 9 \\
\hline 67 & 10.ix.19 & S. & 14 & $6-11$ & 4 & $8-11$ \\
\hline 68 & , & M. & 3 & $7 \cdot 5-8$ & - & - \\
\hline 69 & 17.ix.19 & B. & 1 & 6 & - & - \\
\hline 75 & 19.ix.19 & M. & 1 & 7 & - & - \\
\hline 76 & 25.ix.19 & B. & 4 & $7-9$ & - & - \\
\hline 79 & . & M.-B. & 2 & $9 \cdot 5-10 \cdot 5$ & - & - \\
\hline 80 & , & M. -B. & 3 & $7-9.5$ & - & - \\
\hline
\end{tabular}


TABLE XLI.

Apparatus C.

RECORD OF Trachinus VIPERA.

\begin{tabular}{ccccc}
$\begin{array}{c}\text { No. of } \\
\text { Haul. }\end{array}$ & Date. & Depth. & \multicolumn{2}{c}{ Trachinus vipera. } \\
20 & $16 . i x .19$ & B. & 1 & Size in mm. \\
22 & ", & B. & 1 & 78 \\
23 & " & B. & 1 & 88 \\
24 & $18 . i x .19$ & B. & 14 & $59-88$ \\
25 &,$\%$ & B. & 16 & $68-98$
\end{tabular}

\section{SCOMBROIDEI.}

\section{Scomber scomber L. Mackerel.}

The early young of the Mackerel were moderately plentiful during the autumn of 1919. One hundred and seventy-eight post-larvæ from 5 to $13.5 \mathrm{~mm}$. occurred in 30 hauls of the trawls A and B during July and the first half of August. No post-larvæ were taken after August 13th and no adolescent stages were found, though a special search was made for these forms both in the shallower water of the bays and in the deeper waters in midchannel. Dr. Allen (1917) recorded a similar number of post-larvæ for the year 1914, and these were taken chiefly in May and June. The largest post-larva was $16 \mathrm{~mm}$., and was secured in July. There are few post-larvæ over $12 \mathrm{~mm}$. in length in the collections for these two years, and this is evidently about the average length at which they disappear near Plymouth. The pectoral and caudal fins are strongly developed at an early age, the young fish soon become active swimmers and apparently are able to avoid capture. It seems highly probable that the young gather in shoals, well offshore and return to the bays for feeding purposes the following year.

The spawning period of the Mackerel occurs from May to July at Plymouth. There are no records of spawning earlier than May month, though a later spawning has been observed for some years, vide Lebour (1918) for the record of post-larvæ in September, 1917. The young fish from 10 to $11.5 \mathrm{~mm}$. secured at the end of May, 1914, were thus probably only about three weeks old. As the length of the newly hatched larva is about $3.5 \mathrm{~mm}$. this would give a growth of 6.5 to $8 \mathrm{~mm}$. in three weeks. The slightly larger fish from 43 to $50 \mathrm{~mm}$. (tip of snout to tip of 
eaudal lobes) have seldom been captured, but several were taken by Mr. G. T. Atkinson at this length in latitude $56^{\circ} 20^{\prime} \mathrm{N}$. and longitude $2^{\circ} 23^{\prime} \mathrm{W}$. on August 13th, 1913. These were secured at the surface at night time. In assuming the spawning period for the North Sea to be from May to August, these fish would at most be three months old. The writer, while engaged in naval duties, secured several specimens, 128 to $157 \mathrm{~mm}$. (tip of snout to tip of caudal), in October, 1918, from the stomachs of Haddock and Whiting which were trawled a few miles off the River Tyne. These October specimens (128-157 mm.) when ranged alongside the August specimens $(43-50 \mathrm{~mm}$.) would appear to be fourteen months old, as it seems highly improbable that a $40 \mathrm{~mm}$. fish would increase to $120 \mathrm{~mm}$. in two months. This estimation of the rate of growth of the Mackerel would thus work out at an average of about $10 \mathrm{~mm}$. a month-a figure which agrees well with the rate of growth estimated above for the Plymouth post-larvæ (cf. Allen, 1897, Ehrenbaum, 1912, and Nilson, 1914).

Spawning Period: v-viii. 


\section{TABLE XLII.}

Apparatus A and B.

Record of Scomber scomber.

\begin{tabular}{|c|c|c|c|c|c|c|c|c|c|c|c|c|c|c|c|c|c|c|c|c|}
\hline $\begin{array}{l}\text { No. of } \\
\text { Haul. }\end{array}$ & Date. & Depth. & 5 & $5 \cdot 5$ & 6 & $6 \cdot 5$ & 7 & $7 \cdot 5$ & 8 & $8 \cdot 5$ & 9 & $\begin{array}{r}\text { in } \mathrm{m} \\
9 \cdot 5\end{array}$ & 10 & $10 \cdot 5$ & 11 & $11 \cdot 5$ & 12 & $12 \cdot 5$ & 13 & $13 \cdot:$ \\
\hline .2 & 7.vii. 19 & B. & - & - & - & - & 1 & - & - & - & - & 1 & - & - & - & - & - & - & - & - \\
\hline 3 & 9.vii. 19 & M. & - & - & - & - & - & - & - & 1 & - & - & - & - & - & - & - & - & - & - \\
\hline 4 & 10.vii.19 & B. & 5 & 2 & 4 & 3 & - & - & - & - & - & - & - & - & - & - & - & - & - & - \\
\hline 7 & 18.vii. 19 & M. - B. & - & - & - & - & 1 & 1 & 1 & - & - & - & - & - & - & - & - & - & - & 一 \\
\hline 8 & ,, & M. $-\mathrm{B}$. & - & 1 & - & 2 & 1 & - & 1 & 1 & 2 & 1 & 1 & - & - & - & - & 一 & - & - \\
\hline 9 & & M. $-\mathrm{B}$. & - & - & - & 9 & 1 & - & 1 & 1 & - & - & - & - & - & - & - & - & - & - \\
\hline 10 & 21.vii.19 & B. & - & - & - & - & - & - & - & 2 & 1 & - & - & - & - & - & - & - & - & - \\
\hline 11 & , & B. & - & - & - & - & - & 1 & 2 & 1 & - & - & - & - & 1 & - & - & - & - & - \\
\hline 12 & ," & B. & - & - & - & - & 2 & 1 & 3 & 2 & 2 & 4 & - & 1 & 1 & - & - & - & - & - \\
\hline 13 & ," & B. & - & - & - & - & - & - & 1 & 1 & - & 1 & - & 1 & - & - & - & - & - & - \\
\hline 14 & 24.vii. 19 & M. & - & - & - & - & - & 2 & 2 & 6 & 3 & 1 & 1 & 3 & 2 & - & 1 & 一. & - & - \\
\hline 15 & & S. & - & - & - & 一 & - & - & 一 & 2 & - & - & 1 & 1 & - & - & - & - & - & 一 \\
\hline 21 & 29.vii.19 & B. & - & - & - & - & - & - & 一 & 一 & - & 1 & - & - & - & - & - & - & - & - \\
\hline 22 & , & M. & - & - & - & 2 & 4 & 2 & - & 一 & - & - & 1 & - & - & - & - & - & - & - \\
\hline 23 & ," & S. & - & - & - & 1 & - & - & - & - & - & - & - & - & - & - & - & - & - & - \\
\hline 24 & , & B. & - & - & - & 2 & 1 & - & 1 & - & - & - & 一 & - & - & - & - & - & - & - \\
\hline 25 & , & B. & - & - & 2 & 1 & 2 & - & - & 一 & - & 1 & - & - & - & - & - & 一 & - & - \\
\hline 26 & , & B. & - & - & 1 & 1 & 2 & 2 & 1 & - & - & 1 & - & - & - & 1 & - & - & - & -- \\
\hline 28 & 31.vii.19 & B. & - & - & - & - & - & - & - & 2 & - & 1 & 一 & - & - & - & - & - & - & - \\
\hline 29 & 1.viii.19 & B. & - & 一 & - & - & - & - & - & - & - & 1 & - & - & - & - & - & - & - & - \\
\hline 31 & , & B. & 一 & - & - & - & 1 & 2 & 1 & - & - & 2 & 1 & 1 & 1 & - & - & - & - & - \\
\hline 32 & ,, & S. & - & - & - & - & - & - & 一 & 1 & - & - & - & - & - & - & - & - & - & - \\
\hline 34 & 5.viii.19 & B. & - & - & - & I & - & - & - & - & - & - & 一 & - & - & - & - & - & - & - \\
\hline 35 & & B. & - & - & - & - & - & - & - & 1 & - & - & - & - & - & - & - & - & - & - \\
\hline 37 & ," & B. & - & - & - & - & 1 & 1 & - & - & 1 & - & - & - & - & - & - & - & - & 一 \\
\hline 38 & , & M. & - & - & - & - & 1 & 1 & $\overline{2}$ & - & 1 & - & 一 & - & - & - & - & - & - & - \\
\hline 39 & 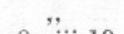 & B. & 1 & 4 & 1 & 2 & - & 2 & 3 & 2 & - & - & 一 & - & - & 一 & - & - & - & - \\
\hline 46 & 8.viii.19 & S. & - & - & - & - & - & 1 & 1 & - & 1 & 一 & - & - & - & - & - & - & - & - \\
\hline 48 & 11.viii.19 & B. & - & - & 一 & - & 1 & 1 & - & 1 & 1 & - & - & - & - & - & - & - & - & $\overline{1}$ \\
\hline 51 & 13.viii.19 & M. & - & - & - & - & - & - & - & - & - & 一 & - & - & - & - & - & - & - & 1 \\
\hline
\end{tabular}




\section{GOBIOIDEI.}

\section{GOBIID Æ.}

\begin{tabular}{|c|c|c|c|}
\hline obIUS & Minutus Pall. & GobIUs & RUTHENSPARRI Euph. \\
\hline " & PICTUS Malm. & 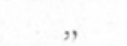 & ELONGatus Canest. \\
\hline & PAGANELLUS I. & " & JEFFREYSII Gunther. \\
\hline & $\begin{array}{l}\text { MICROPS Kroyer. } \\
\text { S scoRPIOIDES Coll. }\end{array}$ & & $\begin{array}{l}\text { NIGER L. } \\
\text { PELLUCIDA (Nardo). }\end{array}$ \\
\hline
\end{tabular}

The young Gobies are referable to the above genera and species, most of which are abundant in the Plymouth area, vide Lebour (1919). The young Fry are produced in large numbers, as many as 4782 specimens having been taken in the young fish trawls A and B during July, August and September, 1919, with an average per haul of $56 \cdot 6$ specimens for this period, the most abundant species in the hauls being Gobius ruthensparri, G. elongatus, G. jeffreysii and Crystallogobius nilssoni. One haul of the young fish trawl B (No. 77) yielded 2269 specimens of $G$. ruthensparri, ranging from 16-52 mm., most of these being adult fish. Gobius elongatus and $G$. jeffreysii occurred most frequently in September, when the average numbers per haul were $19 \cdot 8$ for the former and 18.6 for the latter. Both species were taken at lengths less than $10 \mathrm{~mm}$. from July to September so that spawning takes place for these two species at least during July and August. Most of the Crystallogobius and Aphya are adult fish, few young stages having been captured. The spawning of Crystallogobius has been noted for June, and the appearance of the very young suggests an extension to end of August. Aphya probably spawns slightly earlier in the neighbourhood.

The distribution of the young Gobies is well marked. In the Genus Gobius there are two species, G. elongatus and $G$. jeffreysii, which are distinctly deeper water types. All the young of these two species were captured beyond the 20 -fathom line. The maximum for both is in hauls taken over the greatest depths (total) recorded in this area. The remaining species of Gobius occurred closer inshore, though two species, $G$. minutus and G. pictus, were taken in a few hauls in water just over 20 fathoms. Lebetus scorpioides and Crystallogobius nilssoni are similarly distributed to Gobius elongatus and G. jeffreysii, while Aphya appears in the hauls as an inshore form. The abundance of the Gobies both in the adult and young stages forms an efficient supply of food for some of the commercially more important fishes.

The hauls of the cotton trawl $\mathrm{C}$ are equally interesting and here Gobius minutus is the most abundant, giving an average of 68.8 specimens per haul. One haul of 25 minutes' duration in Cawsand Bay (No. 27) yielded no less than 1532 specimens from $35-73 \mathrm{~mm}$. in length. 


\section{TABLE XLIII.}

Apparatus A and B.

RECORd of Gobius sp.

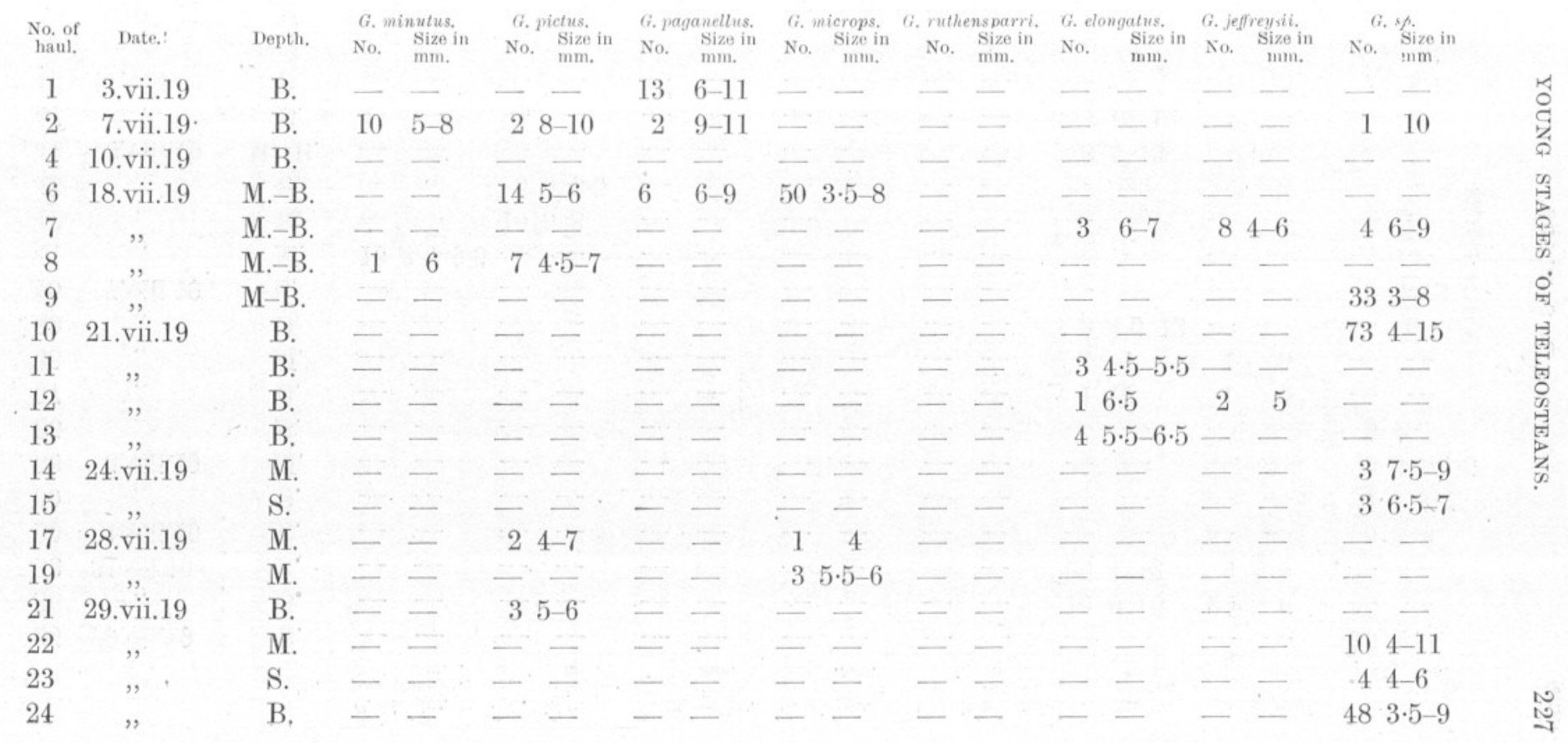




\begin{tabular}{|c|c|c|c|c|c|c|c|c|c|c|c|c|c|c|c|c|c|}
\hline $\begin{array}{l}\text { No. of } \\
\text { haul. }\end{array}$ & Date. & Depth. & $\begin{array}{l}\text { G.min } \\
\text { No. }\end{array}$ & $\begin{array}{l}\text { nutus. } \\
\text { Size in } \\
\text { mm. . }\end{array}$ & $\begin{array}{l}\text { G.p } \\
\text { No. }\end{array}$ & $\begin{array}{l}\text { victus. } \\
\text { Size in. } \\
\text { mm. }\end{array}$ & $\begin{array}{l}\text { G. pag } \\
\text { No. }\end{array}$ & $\begin{array}{l}\text { yanelhis. } \\
\text { Size in. } \\
\text { mm. }\end{array}$ & $\begin{array}{l}\text { G. } m i \\
\text { No. }\end{array}$ & $\begin{array}{l}\text { cropss. } \\
\text { Size in } \\
\text { mm. }\end{array}$ & $\begin{array}{l}\text { G. rith } \\
\text { No. }\end{array}$ & $\begin{array}{l}\text { henspartiri. } \\
\text { Size in } \\
\mathrm{mm} .\end{array}$ & & $\begin{array}{l}\text { longatus, } \\
\text { Size in } \\
\text { mm. }\end{array}$ & & $\begin{array}{l}\text { effreysii. } \\
\text { Size in } \\
\text { mm. }\end{array}$ & $\begin{array}{l}\text { G. sp. } \\
\text { • No. Size in } \\
\text { mm. }\end{array}$ \\
\hline 25 & 29.vii.19 & B. & - & - & - & - & - & - & - & - & - & - & - & - & - & - & $\begin{array}{lll}16 & 4-9\end{array}$ \\
\hline 26 & , & B. & - & - & - & - & - & - & - & - & - & - & 15 & $6-16$ & 24 & $5-6$ & $-\quad-$ \\
\hline 28 & 31.vii.19 & B. & - & - & - & - & - & - & - & - & - & - & 26 & $4-12$ & 9 & 4-9 & -- \\
\hline 29 & 1.viii.19 & B. & - & - & - & - & - & - & - & - & - & - & - & - & - & - & $35-8$ \\
\hline 30 & , & B. & - & - & - & - & - & - & - & - & - & - & - & - & - & - & $4 \cdot 4 \cdot 5-7$ \\
\hline 33 & 5.viii.19 & M. & - & - & - & - & - & - & - & - & - & - & - & - & - & - & $26 \cdot 5-7 \cdot 5$ \\
\hline 35 & ", & B. & - & - & - & - & - & - & - & - & - & - & - & - & - & 一 & $24-7$ \\
\hline 37 & $"$ & B. & - & - & - & - & - & - & - & - & - & - & 1 & 10 & 1 & 5 & -- \\
\hline 38 & ", & M. & - & - & - & - & - & - & - & - & - & - & 1 & 7 & 1 & 5 & -- \\
\hline 39 & ", & B. & - & - & - & - & - & - & - & - & - & - & 3 & $4 \cdot 5-12$ & - & - & -- \\
\hline 40 & 7.viii.19 & S. & - & - & - & 一 & - & - & - & - & - & - & - & - & - & - & $85-12$ \\
\hline 41 & ", & M. & $13:$ & $3 \cdot 5-9 \cdot 5$ & - & - & - & - & - & - & - & - & - & - & - & - & -- \\
\hline 42 & , & B. & - & - & 10 & $5-8$ & - & - & - & - & - & - & - & - & - & - & -- \\
\hline 43 & " & B. & - & - & 5 & $5-9 \cdot 5$ & - & - & - & - & - & - & - & - & - & - & -- \\
\hline 44 & 8.viii.19 & M.-B. & - & - & - & - & - & - & - & - & - & - & 8 & $5-13$ & - & - & -- \\
\hline 47 & ", & B. & - & - & - & - & - & - & - & - & - & - & 3 & $10-12$ & - & - & -- \\
\hline 49 & 11.viii.19 & B. & - & 一 & - & - & - & - & - & - & - & - & - & - & 1 & 6 & $\begin{array}{l}18= \\
\text { G. niger }\end{array}$ \\
\hline 50 & 13.viii.19 & M. & - & - & 3 & & - & - & - & - & - & - & - & - & - & - & $-\quad-$ \\
\hline 51 & , & M. & - & - & 4 & $7-13$ & 1 & 9 & - & - & - & - & - & - & - & - & -- \\
\hline 52 & , & M. & - & - & 8 & $5-13 \cdot 5$ & - & - & - & - & - & - & - & - & - & - & -- \\
\hline 53 & $"$ & M. & - & - & 9 & $4-15$ & - & - & - & - & - & - & - & - & - & - & -- \\
\hline 54 & " & M. & - & - & 7 & $7-13 \cdot 5$ & - & - & - & - & - & - & 一 & - & - & - & - \\
\hline
\end{tabular}




\begin{tabular}{|c|c|c|c|c|c|c|c|c|c|c|c|c|c|c|c|c|c|c|}
\hline $\begin{array}{l}\text { No. of } \\
\text { Haul. }\end{array}$ & Date. & Depth. & & $\begin{array}{l}\text { nutus. } \\
\text { Size in } \\
\text { mm. }\end{array}$ & & $\begin{array}{c}\text { pictuses } \\
\text { Size in } \\
\text { mm. }\end{array}$ & & $\begin{array}{l}\text { anellus. } \\
\text { Size in } \\
\text { mm. }\end{array}$ & & $\begin{array}{l}\text { cirops. } \\
\text { Size in } \\
\text { mm. }\end{array}$ & $\begin{array}{l}\text { ruthe } \\
\text { No. }\end{array}$ & $\begin{array}{c}\text { nsparri. } \\
\text { Size in } \\
\text { mm. }\end{array}$ & $\begin{array}{l}\text { G. elc } \\
\text { No. }\end{array}$ & $\begin{array}{l}\text { longatus. } \\
\text { Size in } \\
\text { mm. }\end{array}$ & & $\begin{array}{l}\text { freysii. } \\
\text { Size in in } \\
\text { mm. }\end{array}$ & & $\begin{array}{l}\text { sp. } \\
\text { Size in } \\
\text { mm. }\end{array}$ \\
\hline 55 & 14.viii.19 & B. & - & - & - & - & - & - & - & - & - & - & - & - & - & - & $110 ?$ & $7-16$ \\
\hline 56 & 15.viii.19 & B. & - & - & - & - & - & - & - & - & - & - & - & - & - & - & 99 ? & $9-15$ \\
\hline 57 & 1.ix.19 & B. & - & - & - & - & - & - & - & - & - & 二 & 22 & $9-13$ & - & - & - & - \\
\hline 58 & $"$ & B. & - & - & 188 & 8-14 & - & - & - & - & 70 & $16-40$ & - & - & - & - & - & - \\
\hline 62 & 9.ix.19. & S." & - & - & - & - & - & - & - & - & - & - & 15 & $13-22$ & 42 & 6-19 & - & - \\
\hline 63 & , & M. & - & - & - & - & - & - & - & - & - & - & 60 & $14-39$ & 165 & $11-32$ & - & - \\
\hline 64 & ", & B. & - & - & - & - & - & - & - & - & - & - & 88 & $16-39$ & 119 & $7-28$ & - & - \\
\hline 65 & $"$ & S. & - & - & - & - & - & - & - & - & - & - & 3 & 11-19 & 7 & 9-19 & - & - \\
\hline 66 & ", & B. & - & - & - & - & - & - & - & - & - & - & 73 & $9-21$ & 51 & $5-19$ & - & - \\
\hline 67 & 10.ix.19 & S. & - & - & - & - & - & - & - & - & - & - & 9 & $9-20$ & 1 & 9 & - & - \\
\hline 68 & $"$ & M. & - & - & - & - & - & - & - & - & - & - & 23 & $17-27$ & 81 & $5-19$ & - & - \\
\hline 69 & 17.ix.19 & B. & - & - & - & - & - & - & - & - & - & - & 4 & $10-13$ & - & - & - & - \\
\hline 70 & , & B. & - & - & - & - & - & - & - & - & - & - & 10 & $9-17$ & - & - & - & - \\
\hline 71 & ", & B. & - & - & - & - & - & - & - & - & - & - & 11 & $9-16$ & - & - & - & - \\
\hline 72 & , & B. & - & - & - & - & - & - & - & - & - & - & 23 & $11 \cdot 5-20$ & - & - & - & - \\
\hline 73 & ", & B. & - & - & - & - & .- & - & - & - & - & - & 101 & $9-24$ & - & - & - & - \\
\hline 76 & 25.ix.19 & B. & - & - & - & - & - & - & - & - & - & - & - & - & - & - & $\begin{array}{ll}2 & 1\end{array}$ & 11-13 \\
\hline 77 & ", & B. & 120 & $44-60$ & - & - & - & - & - & - & 2269 & $16-52$ & - & - & - & - & - & - \\
\hline 78 & ", & B. & - & - & - & - & - & - & - & - & & 22 & - & - & - & - & 17 & 7 \\
\hline 81 & 29.ix.19 & B. & - & - & - & - & - & - & - & - & - & - & 55 & $15-30$ & - & - & - & - \\
\hline
\end{tabular}


TABLE XLIV.

Apparatus C.

RECORD OF Gobius sp.

\begin{tabular}{|c|c|c|c|c|c|c|c|c|c|c|c|c|}
\hline $\begin{array}{l}\text { No. of } \\
\text { haul, }\end{array}$ & Date. & Depth. & $\begin{array}{l}{ }^{G .} \\
\text { No. }\end{array}$ & $\begin{array}{l}\text { ninutus. } \\
\text { izze in mm. }\end{array}$ & & $\begin{array}{l}\text { pictus. } \\
\text { Size in mm. }\end{array}$ & $\begin{array}{l}\text { G. } \\
\text { No. }\end{array}$ & $\begin{array}{l}\text { hensparri. } \\
\text { ize in } \mathrm{mm} \text {. }\end{array}$ & $\begin{array}{l}\text { G.el } \\
\text { No. }\end{array}$ & $\begin{array}{l}\text { ngatus. } \\
\text { ize in } \mathrm{mm} \text {. }\end{array}$ & $\begin{array}{l}\text { a.je. } \\
\text { No. }\end{array}$ & $\begin{array}{l}\text { reysiii. } \\
\text { ze in } \mathrm{mm} \text {. }\end{array}$ \\
\hline 4 & 25.viii.19 & B. & 37 & $33-52$ & 9 & $30-47$ & 21 & $24-35$ & - & - & - & - \\
\hline 5 & 26.viii.19 & B. & 18 & $27-60$ & 3 & 50 & 106 & $23-45$ & - & - & - & \\
\hline 6 & 3.ix.19 & B. & - & - & - & - & - & - & 3 & $7-24$ & 2 & 29-32 \\
\hline 8 & 8.ix.19 & M. & - & - & - & - & & - & 1 & 32 & - & - \\
\hline 9 & & B. & - & - & - & - & - & - & 9 & $25-43$ & 1 & 28 \\
\hline 11 & 9.ix.19 & B. & - & - & - & - & & - & 5 & $27-35$ & - & - \\
\hline 12 & ", & M. & - & & & & - & - & 5 & $14-35$ & 2 & $28-41$ \\
\hline 13 & ", & M. & & - & - & - & & & 5 & $14-37$ & - & - \\
\hline 15 & " & M. & - & - & - & - & - & - & 4 & $29-35$ & 5 & $24-42$ \\
\hline 16 & 10.ix.19 & S. & & - & - & - & - & - & 1 & 17 & - & - \\
\hline 17 & 12.ix.19 & B. & - & - & - & - & - & - & 2 & 36 & - & - \\
\hline 18 & & B. & - & - & - & - & - & - & 3 & $44-50$ & - & - \\
\hline 20 & 16.ix.19 & B. & 6 & $37-85$ & - & - & - & - & - & - & & - - \\
\hline 21 & , & B. & 53 & $40-80$ & - & - & - & - & - & - & - & - \\
\hline 22 & $"$ & B. & 62 & $32-75$ & - & - & - & - & - & - & - & - \\
\hline 23 & ", & B. & 129 & $33-80$ & - & - & - & - & - & - & - & - \\
\hline 24 & 18.ix.19 & B. & 80 & $33-80$ & - & - & - & - & - & - & - & - \\
\hline 25 & & B. & 6 & $40-70$ & - & - & - & - & - & - & - & - \\
\hline 26 & 23.ix.19 & B. & 181 & $40-68$ & - & - & 50 & $33-47$ & - & - & - & - \\
\hline 27 & & B. & 1532 & $35-73$ & 3 & $41-50$ & 14 & $32-44$ & 一 & - & - & - \\
\hline 30 & 29.ix.19 & B. & 27 & $28-62$ & - & - & - & - & - & - & - & - \\
\hline 31 & $"$ & B. & 5 & $40-56$ & - & - & - & - & - & - & - & - \\
\hline
\end{tabular}


TABLE XLV.

Apparatus A and B.

Record of Crystallogobius and Aphya.

\begin{tabular}{|c|c|c|c|c|c|c|}
\hline No. of & Date. & Depth. & & C. nilssoni. & & pellucida. \\
\hline Haul. & Date. & Deptil. & No. & Size in $\mathrm{mm}$. & No. & \\
\hline 1 & 3.vii.19 & B. & 2 & $42-44$ & - & - \\
\hline 19 & 28.vii.19 & M. & 1 & 4 & 一 & - \\
\hline 22 & 29.vii.19 & M. & 1 & 4 & 一 & - \\
\hline 27 & 31.vii.19 & S. & $\cdot-$ & - & 1 & 54 ô \\
\hline 28 & " & B. & 3 & $\begin{array}{l}1 \text { at } 23 \hat{\circ} \\
2 \text { at } 28-29 \text { 우 }\end{array}$ & 1 & 47 우 \\
\hline 57 & 1.ix.19 & B. & 3 & $14-31$ & 一 & - \\
\hline 62 & 9.ix.19 & S. & 62 & $5-25$ & 一 & 一 \\
\hline 63 & " & M. & 11 & $5 \cdot 5-31$ & 一 & - \\
\hline 64 & , & B. & 102 & $4-32$ & - & 一 \\
\hline 65 & , & S. & 17 & $9-29$ & - & - \\
\hline 66 & $"$ & B. & 53 & $4-34$ & - & 一 \\
\hline 67 & 10.ix.19 & S. & 2 & $10-15$ & 一 & - \\
\hline 68 & , & M. & 29 & $6-22$ & - & - \\
\hline 69 & 17.ix.19 & B. & 9 & $10-36$ & - & - \\
\hline 70 & $"$ & B. & 10 & $9-25$ & - & - \\
\hline 71 & , & B. & 16 & $11-30$ & - & - \\
\hline 72 & , & B. & 9 & $17-31$ & - & 一 \\
\hline 73 & , & B. & 21 & $15-44$ & - & 一 \\
\hline 76 & 25.ix.19 & B. & - & - & 3 & $19-23$ \\
\hline 77 & " & B. & - & - & 16 & $21-50$ \\
\hline 78 & , & B. & - & - & 8 & $19-26$ \\
\hline 81 & 29.ix.19 & B. & 224 & $14-31$ & - & - \\
\hline
\end{tabular}

TABLE XLVI.

Apparatus C.

Record of Crystallogobius and Aphya.

\begin{tabular}{ccccccc} 
No. of & Date. & Depth. & \multicolumn{2}{c}{ C. nilssoni. } & \multicolumn{2}{c}{ A. pellucida. } \\
Haul. & No. & Size in mm. & No. & Size in \\
4 & $25 . v i i i .19$ & B. & - & - & 1 & 45 \\
5 & 26. viii.19 & B. & - & - & 1 & 48 \\
6 & 3.ix.19 & B. & 5 & $30-38$ & - & - \\
13 & 9. ix.19 & M. & 1 & 11 & - & - \\
14 & " & S. & 1 & 16 & - & - \\
16 & $10 . i x .19$ & S. & 3 & $5-10$ & - & - \\
19 & 16.ix.19 & M. & - & - & 1 & 20
\end{tabular}




\section{TABLE XLVII.}

\section{Apparatus A AND B.}

ReCord of Lebetus Scorpioides.

$\begin{array}{ccccc}\begin{array}{c}\text { No. of } \\ \text { Haul. }\end{array} & \text { Date. } & \text { Depth. } & \text { No. } & \text { Size in mm. } \\ 1 & \text { 3.vii.19 } & \text { B. } & 1 & 6 \cdot 5 \\ 13 & \text { 21.vii.19 } & \text { B. } & 1 & 5 \\ 28 & \text { 31.vii.19 } & \text { B. } & 2 & 4-7 \\ 38 & \text { 5.viii.19 } & \text { M. } & 1 & 6 \\ 39 & \text { " } & \text { B. } & 2 & 5-6 \\ 45 & \text { 8.viii.19 } & \text { M. } & 1 & 7 \\ 47 & \text { "Nii.19 } & \text { B. } & 2 & 6-7 \\ 48 & \text { B. } & 1 & 5 \\ 62 & 9 . i x .19 & \text { S. } & 1 & 5 \\ 63 & \text { ". } & \text { M. } & 10 & 9-12\end{array}$

\section{BLENNIOIDEI.}

\section{BLENNIID $Æ$ BLENNIES.}

The pelagic young Blennies occur in 34 hauls, with an average per haul of 1.3 specimens. These are mostly Blennius ocellaris, whose spawning period extends from June to August in the neighbourhood. The distribution is general and again suggests inshore and offshore types, the offshore type being $B$. ocellaris. The early young of this species resemble closely the young of the Mackerel, at the same size.

TABLE XLVIII.

\section{Apparatus A and B.}

\section{Record of Blennius sp.}

$\begin{array}{ccccc}\begin{array}{c}\text { No of } \\ \text { Haul. }\end{array} & \text { Date. } & \text { Depth. } & \text { No. } & \text { Size in mm. } \\ 2 & \text { 7.vii.19 } & \text { B. } & 5 & 6-7 \\ 3 & 9 . \text { vii.19 } & \text { M. } & 1 & 7 \\ 5 & 11 . v i i .19 & \text { B. } & 1 & 5 \\ 7 & 18 . v i i .19 & \text { M.-B. } & 3 & 4-6 \\ 8 & \text { ", } & \text { M.-B. } & 3 & 3-8 \\ 12 & 21 . v i i .19 & \text { B. } & 2 & 5-8 \\ 13 & ,, & \text { B. } & 9 & 6-7\end{array}$


YOUNG STAGES OF TELEOSTEANS.

\begin{tabular}{|c|c|c|c|c|}
\hline $\begin{array}{l}\text { No. of } \\
\text { Haul. }\end{array}$ & Date. & Depth. & No. & Size in $\mathrm{mm}$. \\
\hline 14 & 24.vii.19 & M. & 15 & $4-8$ \\
\hline 15 & , & S. & 8 & $4-8$ \\
\hline 17 & 28.vii.19 & M. & 3 & $8-8.5$ \\
\hline 18 & , & M.-B. & 6 & $6-10$ \\
\hline 19 & , & M. & 13 & $4 \cdot 5-8$ \\
\hline 20 & 29.vii.19 & B. & 6 & $10-12$ \\
\hline 21 & , & B. & 6 & $5-6$ \\
\hline 22 & , & M. & 2 & $5-7$ \\
\hline 23 & , & S. & 1 & $6 \cdot 5$ \\
\hline 24 & 1, & B. & 4 & $7-9$ \\
\hline 27 & 31.vii.19 & S. & 1 & 7 \\
\hline 29 & 1.viii.19 & B. & 4 & $5 \cdot 5-6 \cdot 5$ \\
\hline 30 & , & B. & 2 & $5-7$ \\
\hline 31 & ,; & B. & 2 & $6 \cdot 5-8$ \\
\hline 33 & 5.viii.19 & M. & 2 & $5-6.5$ \\
\hline 35 & , & B. & 4 & 6 \\
\hline 36 & , & S. & 2 & $6 \cdot 5-9$ \\
\hline 37 & , & B. & 1 & 5 \\
\hline 41 & 7.viii.19 & M. & 1 & 7 \\
\hline 42 & , & B. & 1 & 8 \\
\hline 46 & 8.viii.19 & S. & 2 & $7-7 \cdot 5$ \\
\hline 47 & , & B. & 2 & $6 \cdot 5-8$ \\
\hline 49 & 11.viii.19 & B. & 1 & 6 \\
\hline 57 & 1.ix.19 & M. & 1 & 8 \\
\hline 62 & 9.ix.19 & S. & 1 & 14 \\
\hline 65 & , & S. & 1 & 12 \\
\hline 80 & 25.ix.19 & M.-B. & 1 & $8 \cdot 5$ \\
\hline
\end{tabular}

\section{SCLEROPAREI.}

SCORP ANOIDEA. SCORP ENIFORMES.

\section{TRIGLID Æ.}

Trigla gurnardus L. Grey Gurnard.

cuculus L. Red Gurnard.

" hirundo Bl. Sapphirine Gurnard (Tub).

" Lineata L. Streaked Gurnard (Polperro Bull dog).

The material collected from July to end of September, 1919, contains 501 examples of the pelagic young Gurnards, which occurred in 51 hauls of the young fish trawls $\mathrm{A}$ and $\mathrm{B}$, an average of 5.9 specimens per haul 
for the whole period. The determination of the species has been rather difficult, owing to the similarity of the young forms, more especially those before the formation of the dorsal and anal fin rays. T. gurnardus, however, and $T$. cuculus are the predominant species, and they occur often in the same haul. Of the former species, little doubs may be attached to the identification, which is in agreement with that of other authors, notably M'Intosh and Prince (1890), M'Intosh and Masterman (1897), Ehrenbaum (1905-1909), and Fage (1918).

$T$. cuculus, so far as examination of known literature goes, is practically an unknown quantity, but the writer is strongly convinced that the material under investigation and recorded here as Trigla sp. B. belongs almost solely to this species, though one or two represent the very early young of $T$. hirundo (cf. Jaquet, 1907) and $T$. lineata. Confirmation of the last species was obtained by securing a good artificial fertilization and by rearing the larva to the period of the absorption of the yolk sac. Investigation on the early young stages is being continued and the results will be published in due course.

The pelagic young of $T$. gurnardus are distributed generally over the shallower and deeper waters. $T$. cuculus seems to show a maximum number over depths greater than 20 fathoms, occurring only occasionally in the shallower water.

There is not much difficulty in the determination of the adolescent stages. The hauls of the cotton trawl $\mathrm{C}$ contain examples of three species, T. gurnardus, cuculus and hirundo, while $T$. lineata is absent. $T$. gurnardus and $T$. hirundo were taken in water of 4-6 fathoms in. Whitsand Bay, showing that these two species come inshore during their adolescent stage. T. cuculus, on the other hand, has not been taken in the adolescent stage in water less than 20 fathoms in depth, several adolescent stages having been taken from time to time in small meshed nets attached to the otter trawl in the area between Rame Head and Eddystone and in the deeper mid-channel waters. $T$. lineata has a similar distribution to $T$. cuculus, and only one adolescent stage has been observed by the writer, a specimen of $85 \mathrm{~mm}$., which was taken in the deeper water off Whitsand Bay.

T. lyra, another deep water form, so far has not been observed in the early stages, nor has the adult been observed in spawning condi'ion.

$\begin{array}{ccccc} & \text { T. gurnardus. } & \text { T. cuculus. } & \text { T. hirundo. } & \text { T. lineata. } \\ \text { Spawning Period : } & \text { i-viii. } & \text { iv-viii. } & \text { vi. } & \text { vi-vii. }\end{array}$




\section{TABLE XLIX.}

Apparatus A and B.

Record of Trigla sp.

\begin{tabular}{|c|c|c|c|c|c|c|}
\hline No. of & & & & nardus. & & la sp. B. \\
\hline $\begin{array}{c}\text { Haul. } \\
3\end{array}$ & $\begin{array}{l}\text { Date. } \\
\text { 9 vii } 19\end{array}$ & Depth. & No. & Size in $\mathrm{mm}$. & No. & Size in $\mathrm{mm}$ \\
\hline 3 & 9.vii.19 & M. & 一 & - & 2 & $4 \cdot 5-5 \cdot 5$ \\
\hline 4 & 10.vii.19 & B. & 9 & $6 \cdot 5-8$ & 12 & $6-18$ \\
\hline 5 & 11.vii.19 & B. & 7 & $6-8 \cdot 5$ & - & 一 \\
\hline 6 & 18.vii.19 & M.-B. & - & - & 1 & 5 \\
\hline 7 & , & M.-B. & 7 & $9-13 \cdot 5$ & 1 & 6 \\
\hline 8 & " & M.-B. & 2 & $9-9 \cdot 5$ & 2 & $7 \cdot 5-8 \cdot 5$ \\
\hline 9 & ", & M.-B. & 10 & $7-12$ & 25 & $4-8 \cdot 5$ \\
\hline 10 & 21.vii.19 & B. & 8 & $7-13$ & 13 & $5 \cdot 5-11 \cdot 5$ \\
\hline 11 & ", & B. & 37 & $4.5-10 \cdot 5$ & 17 & $4-10 \cdot 5$ \\
\hline 12 & , & B. & 60 & $5-13$ & 11 & $5 \cdot 5-9$ \\
\hline 13 & ", & B. & 22 & $6 \cdot 5-13 \cdot 5$ & - & - \\
\hline 15 & 24.vii.19 & S. & 4 & $10-12$ & - & - \\
\hline 16 & , & M. & 2 & $8 \cdot 5-12$ & - & - \\
\hline 17 & 28.vii.19 & M. & 3 & $8-12 \cdot 5$ & 2 & $8-9$ \\
\hline 18 & , & M.-B. & 3 & $6 \cdot 5-11$ & - & - \\
\hline 19 & , & M. & 1 & $6 \cdot 5$ & - & - \\
\hline 20 & 29.vii.19 & M. & 1 & 7 & - & - \\
\hline 22 & ", & M. & 6 & $6-9 \cdot 5$ & - & - \\
\hline 24 & $"$ & B. & 1 & $8 \cdot 5$ & 17 & $5-9$ \\
\hline 25 & , & B. & 20 & $5 \cdot 5-10$ & 3 & $5-7$ \\
\hline 26 & $"$ & B. & 25 & $5-16$ & 4 & $5-12$ \\
\hline 28 & 31.vii.19 & B. & 12 & $6-15$ & 9 & $5 \cdot 5-10$ \\
\hline 30 & 1.viii.19 & B. & 2 & $7-10 \cdot 5$ & - & - \\
\hline 31 & , & B. & 13 & $6-17 \cdot 5$ & 6 & 6 \\
\hline 32 & , & S. & 2 & $7-8$ & - & - \\
\hline 33 & 5.viii.19 & M. & 2 & $9 \cdot 5-12$ & - & - \\
\hline 34 & , & B. & 3 & $6-15$ & 1 & 6 \\
\hline 37 & $"$ & B. & 3 & $7-9 \cdot 5$ & 6 & $5-7$ \\
\hline 38 & $"$ & M. & 1 & 7 & 3 & $5-6$ \\
\hline 39 & , & B. & - & - & 1 & 5 \\
\hline 41 & 7.viii.19 & M. & 1 & 10 & - & - \\
\hline 42 & , & B. & 3 & $6-12$ & - & - \\
\hline 43 & ", & B. & 9 & $7-11$ & 1 & $7 \cdot 5$ \\
\hline 44 & 8.viii.19 & M.-B. & 2 & $7-8$ & 5 & $5-9$ \\
\hline 45 & , & M. & 3 & $6-10$ & - & - \\
\hline 47 &, & B. & - & - & 8 & $5-11$ \\
\hline 48 & 11.viii.19 & B. & 3 & $7-16$ & 10 & $5-7 \cdot 5$ \\
\hline
\end{tabular}




\begin{tabular}{|c|c|c|c|c|c|c|}
\hline No. of & & & & irnardus. & & igla sp B. \\
\hline Haul. & $\begin{array}{c}\text { Date. } \\
\text { iii }\end{array}$ & Depth. & No. & Size in $\mathrm{mm}$. & No. & Size in $\mathrm{mm}$. \\
\hline 49 & & & & & - & \\
\hline 51 & 13.viii.19 & M. & 1 & 7 & - & - \\
\hline 52 & ," & M. & - & - & 1 & 6 \\
\hline 54 & , & M. & 1 & $6 \cdot 5$ & 1 & 6 \\
\hline 55 & 14.viii.19 & B. & 1 & 8 & 1 & 13 \\
\hline 56 & 15.viii.19 & B. & 26 & $7-13$ & 6 & $7-10 \cdot 5$ \\
\hline 57 & 1.ix.19 & B. & 2 & $6-10$ & 1 & 10 \\
\hline 58 & ", & B. & 1 & 7 & - & - \\
\hline 60 & 3.ix.19 & M. & 1 & 9 & 1 & 7 \\
\hline 61 & , & B. & - & - & 1 & 8 \\
\hline 62 & 9.ix.19 & S. & 1 & 6 & - & - \\
\hline 65 & , & S. & - & - & 1 & 11 \\
\hline 66 & , & B. & - & - & 1 & $7 \cdot 5$ \\
\hline 79 & 25.ix.19 & - & - & - & 1 & 20 \\
\hline
\end{tabular}

\section{TABLE L.}

Apparatus C.

Record of Trigla sp.

\begin{tabular}{|c|c|c|c|c|c|c|c|c|}
\hline $\begin{array}{l}\text { No. of } \\
\text { haul. }\end{array}$ & Date. & Depth. & $\begin{array}{r}T . \\
\text { No. }\end{array}$ & $\begin{array}{l}\text { gurnardus. } \\
\text { Size in mm. }\end{array}$ & No. & $\begin{array}{l}\text { cuculus. } \\
\text { ize in } \mathrm{mm} .\end{array}$ & ${ }^{T}{ }^{T}$ & $\begin{array}{l}\text { hirundo. } \\
\text { Size in } \mathrm{m}\end{array}$ \\
\hline 7 & 8.ix.19 & S. & 1 & 19 & - & - & - & - \\
\hline 8 & , & M. & - & - & 1 & 16 & - & - \\
\hline 10 & , & S. & 1 & 22 & - & - & 1 & 15 \\
\hline 12 & 9.ix.19 & M. & - & - & 1 & 22 & - & - \\
\hline 16 & 10.ix.19 & S. & 2 & 18 & - & - & - & - \\
\hline 17 & 12.ix.19 & B. & 1 & 57. & - & - & - & - \\
\hline 18 &, & B. & - & - & 1 & 48. & - & - \\
\hline 20 & 16.ix.19 & B. & 1 & 78 & - & - & - & - \\
\hline 22 & , & B. & - & - & - & - & 9 & $75-110$ \\
\hline 25 & 18.ix.19 & B. & - & - & - & - & 1 & 82 \\
\hline 30 & 29.ix.19 & B. & 5 & $47-70$ & - & - & - & - \\
\hline
\end{tabular}

COTTIFORMES.

\section{AGONIDAE.}

Agonus cataphractus L. Pogge.

No pelagic young of this species were secured. Two bottom stages, ca. $55 \mathrm{~mm}$. in-length, were captured in the cotton trawl C, one in Haul 22 on 16th September, 1919, and one in Haul 24 on 18th September, 1919, both in Whitsand Bay East in depths from 4 to 6 fathoms. The species is not uncommon in the neighbourhood.

Spawning Period: iii-iv. 


\section{CYCLOPTERID $A$.}

\section{Liparis Montagui Donov.}

One post-larva, $6 \mathrm{~mm}$. in length, occurred in Haul 6 of the young fish trawl A on 18th July, 1919 (midwater to bottom). There are comparatively few records of this species in the early stages, but the adult occurs close in shore fairly frequently.

\section{GASTROSTEOIDEA.}

\section{GASTROSTEID \&.}

\section{SPINACHIA vUlgaris Flem.}

No early pelagic stages of this species were taken. The captures of the cotton net $\mathrm{C}$ ranged from $61-95 \mathrm{~mm}$. in length, and these were adults. The species is extremely common in the shallower waters close inshore, being very abundant in the Zostera bed of Cawsand Bay.

\section{TABLE LI.}

Apparatus C.

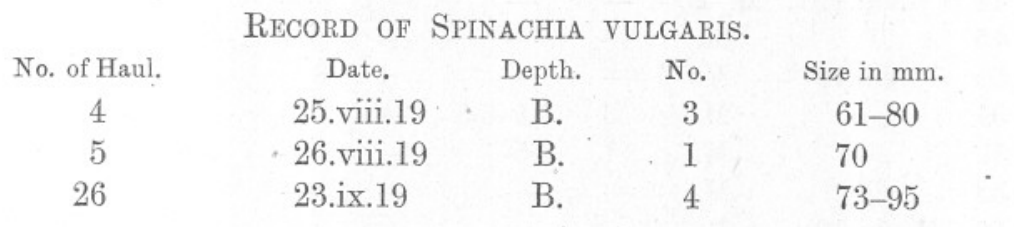

\section{XENOPTERI.}

\section{GOBIESOCID $\approx$.}

Lepadogaster bimaculatus Penn.

" GOUANI Lacep.

" CANDOLLI L.

The hauls of the young fish trawls A and B contain the above three species. Two are inshore forms- $L$. gouani and $L$. candolli-while $L$. bimaculatus appears to be a definite offshore type, and is the only one of the three species which was taken in the deeper water hauls. The post-larvæ of $L$. bimaculatus are scattered over the whole of the area, 43 specimens having been taken from end of July to middle of September. Two adults, 33 to $35 \mathrm{~mm}$. occurred in Haul 6 of the cotton trawl C on 3rd September, 1919, at a depth of 27 fathoms in locality 5 miles west of Rame Head.

Spawning Period: L. bimaculatus, v-viii. 


\section{TABLE LII.}

Apparatus A AND B.

RECord of Lepadogaster sp.

\begin{tabular}{|c|c|c|c|c|c|c|c|c|}
\hline $\begin{array}{l}\text { No. of } \\
\text { haul. }\end{array}$ & Date. & Depth. & $\begin{array}{r}L . \\
\text { No. }\end{array}$ & $\begin{array}{l}\text { andolli. } \\
\text { ize in mm. }\end{array}$ & No. ${ }^{I}$ & $\begin{array}{l}\text { gouani. } \\
\text { Size in } \mathrm{mm} .\end{array}$ & $\begin{array}{l}L . b \\
\text { No. }\end{array}$ & $\begin{array}{l}\text { maculatus } \\
\text { Size in } n\end{array}$ \\
\hline 1 & 3.vii. 19 & B. & 1 & 7 & - & - & - & - \\
\hline 2 & 7.vii.19 & B. & - & - & 1 & 6 & - & - \\
\hline 6 & 18.vii.19 & M.-B. & 9 & $5 \cdot 5-7$ & 3 & 6 & - & - \\
\hline 8 & ", & M.-B. & 1 & 6 & - & - & - & - \\
\hline 14 & 24.vii.19 & M. & 1 & 6 & - & - & - & - \\
\hline 28 & 31.vii.19 & B. & - & - & - & - & 1 & 9 \\
\hline 30 & 1.viii.19 & B. & 1 & 6 & - & - & - & - \\
\hline 34 & 5.viii.19 & B. & - & - & - & - & 1 & $6 \cdot 5$ \\
\hline 37 & ,, & B. & - & - & - & - & 3 & $4-9$ \\
\hline 40 & 7.viii.19 & S. & - & - & - & - & 1 & 6 \\
\hline 41 & , & M. & 5 & $4-6.5$ & - & - & 5 & $4-6 \cdot 5$ \\
\hline 42 & ", & B. & 4 & $5 \cdot 5-7$ & - & - & 1 & 6.5 \\
\hline 43 & , & B. & 5 & $6-7$ & - & - & 1 & 5 \\
\hline 44 & 8.viii.19 & M.-B. & - & - & - & - & 3 & $4-10$ \\
\hline 45 & , & M. & - & - & - & - & 2 & $9-9 \cdot 5$ \\
\hline 50 & 13.viii.19 & M. & - & - & 1 & 8 & - & - \\
\hline 51 & , & M. & 3 & $5 \cdot 5-6 \cdot 5$ & - & - & 1 & 5 \\
\hline 52 & , & M. & 1 & $5 \cdot 5$ & - & - & - & - \\
\hline 53 & ", & M. & - & - & - & - & 1 & 6 \\
\hline 56 & 15.viii.19 & B. & - & - & - & - & 7 & $7-10$ \\
\hline 58 & 1.ix.19 & B. & - & - & 1 & 4 & 1 & 9 \\
\hline 61 & 3.ix.19 & B. & - & - & - & - & 1 & 7 \\
\hline 62 & 9.ix.19 & S. & - & - & - & - & 1 & 10 \\
\hline 63 & , & M. & - & - & - & - & 2 & $13-14$ \\
\hline 65 & , & S. & - & - & - & - & 1 & 8 \\
\hline 66 & , & B. & - & - & - & - & 7 & $6-12$ \\
\hline 68 & 10.ix.19 & M. & - & - & - & - & 1 & 11 \\
\hline 70 & 17.ix.19 & B. & - & - & - & - & 1 & 7 \\
\hline 72 & , & B. & - & - & - & - & 1 & 11.5 \\
\hline
\end{tabular}




\section{LITERATURE CITED.}

1888. Marion, A. F.-La Sardine sur les côtes de Marseille Comptes. Rendues des Séances de l'Académie des Sciences CVI.

1888. Pouchet, G.--Rapport à M. le Ministère sur le functionnement du Laboratoire de Concarneau. XXV. Paris. Imprimerie Nationale.

1890. McIntosh, W. C., and Prince, E.-Development and Life Histories of the Teleostean Food and other Fishes: Trans. Roy. Soc., Edin. XXXV, p. 111, No. 19.

1891. Cunningham, J. T.-On the Rate of Growth of some Sea Fishes, and the Age and Size at which they begin to Breed. Jour. Mar. Biol. Assoc. Vol. 2. 1891-2.

1893. Holt, E. W. L.-On the Eggs and Larval and Post-Larval Stages of Teleosteans. Sci. Trans. Royal Dublin Society. Vol. V (Series II).

1893. Cunningham, J. T. C.-The Life History of the Pilchard. Jour. Mar. Biol. Assoc. Vol. III. 1893-5.

1895. Garstang, W.-Faunistic Notes at Plymouth during 1893-4. Jour. Mar. Biol. Assoc. Vol. III. N.S. 1893-5.

1896. Cunningham, J. T.-The Natural History of the Marketable Marine Fishes of the British Isles. Macmillan and Co., London.

1897. Allen, E. J.-Report on the present state of knowledge with regard to the Habits and Migrations of the Mackerel. Jour. Mar. Biol. Assoc. Vol. V. 1897-9.

1897. McIntosh, W. C., and Masterman, A. T.-The Life Histories of the British Marine Food Fishes. C. J. Clay and Sons, London.

1899. Cunningham, J. T.-The Capture of Small Pilchards for the Sardin Industry. Cornwall County Council. E. H. Ruscoe, Louth.

1900. Cunningham, J. T.-Fishing with small meshed nets for small Pilchards. Cornwall County Council. J. Lander, Helston.

1904. Petersen, C. G. J.-On the Larval and Post-Larval Stages of the Long Rough Dab and the genus Pleuronectes. Med. Komm. Havund. Fisker. Bd. 1.

1905-09. Ehrenbaum, E.-Eier und Larven von Fischen. Nordisches Plankton. Kiel and Leipzig.

1905. Holt, E. W. L., and Byrne, L. W.-Figures and Descriptions of the British and Irish Species of Solea. Anv. Rep. Fish., Ireland. 1902-03. Part II. App. V. 1905.

1906. Schmidt, Johs.-On the Pelagic Post-Larval Stages of the Lings. Medd. Komm. Havund. Fiskeri. Bind II, No. 3.

1907 (a). Do.-On the Post-Larval Development of the Hake. Medd. Komm. Havund. Fiskeri. Bind II, No. 7.

1907 (b). Do.-On the Post-Larval Development of some North Atlantic Gadoids (Raniceps raninus and Molva elongata). Medd. Komm. Havund. Fiskeri. Bind II, No. 8. 
1907. JAQuet, M.-Note sur une forme jeune de Trigla. Bull. Ocean. Monaco. No. 102.

1909. Schмidt, Johs.- The Distribution of the Pelagic Fry and the Spawning Regions of the Gadoids in the North Atlantic from Iceland to Spain. Rapp. et Procés Verb. Vol. X.

1909. Lo Branco, S.-Notizie biologiche riguardanti specialmente il periodo di maturita sessuale degli animali del golfo di Napoli. Mittheil. Zool. Stat. Neapel. XIX.

1909. Regan, C. T.-The Classification of Teleostean Fishes. Ann. Mag. Nat. Hist. Vol. III, 8th Series.

1909. Petersen, C. G. J.-On the Larval and Post-Larval Stages of some Pleuronectidæ. Medd. Komm. Havund. Fisker. Bind III.

1912. Ehrenbaum, E.-Report on the Mackerel. Conseil permanent ponr l'exploration de la Mer. Rapports XIV.

1913. Kyle, H. M.-Flat Fisheș (Heterosomata). Report on the Danish Oceanographical Expeditions, 1908-10. Vol. II, A.1. No. 2. Biology.

1913. HJont, Johan.-Den Franske Industries Kamp mot de Norske Sardiner. Aarsberetning. Norges Fiskerier. 4de Hefte.

1913. FAGE, L.-Recherches sur la Biologie de la Sardine. Archiv. Zool. Expér. et Général. Tome 52.

1914. Clark, R. S.-General Report on the Larval and Post-Larval Teleosteans in Plymouth Waters. Jour. Mar. Biol. Assoc. Vol. X, No. 2.

1914. Nilsson, D.-A Contribution to the Biology of the Mackerel. Publications de Circonstance. No. 69.

1916. Regan, C. T.-Larval and Post-Larval Fishes. Brit. Antarctic (Terra Nova) Expedition, 1910. Zool. Vol. I, No. 4.

1917. Allex, E. J.-Post-Larval Teleosteans collected near Plymouth during the Summer of 1914. Jour. Mar. Biol. Assoc. Vol. XI, No. 2.

1918. Lebour, M. V.-The Food of Post-Larval Fish, No. 1. Jour. Mar. Biol. Assoc. Vol. XI, No. 4. 1918.

1918. FAGE, L.-Shore Fishes. Report on the Danish Oceanographical Expeditions, 1908-10, to the Mediterranean and Adjacent Seas. No. 4, Vol. II, A. 3.

1919. Lebour, M. V.-The Food of Post-Larval Fish, No. 11. Jour. Mar. Biol. Assoc. Vol. XII, No. 1.

1919. Do.-The Young of the Gobiidæ from the Neighbourhood of Plymouth. Jour. Mar. Biol. Assoc. Vol. XII, No. 1. 